UNIVERSIDADE DE SÃO PAULO.

FACULDADE DE FILOSOFIA, LETRAS E CIÊNCIAS HUMANAS.

DEPARTAMENTO DE LETRAS CLÁSSICAS E VERNÁCULAS.

PROGRAMA DE PÓS-GRADUAÇÃO EM ESTUDOS COMPARADOS DE LITERATURAS DE LÍNGUA PORTUGUESA.

\title{
CONTOS DE FADAS: UM PERCURSO HISTÓRICO-LITERÁRIO DAS IMAGENS DA MULHER.
}

\section{RENATA ZUOLO CARVALHO.}

Dissertação apresentada ao programa de PósGraduação em Estudos Comparados de Literaturas de Língua Portuguesa do Departamento de Línguas Clássicas e Vernáculas da Faculdade de Filosofia, Letras e Ciências Humanas da Universidade de São Paulo, para a obtenção do título de Mestre em Letras.

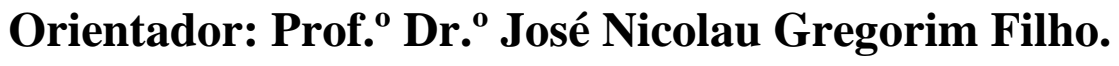

\author{
São Paulo
}

2009. 
RESUMO: essa dissertação de mestrado interpreta quatro obras da literatura infanto-juvenil, focando sua análise nas personagens femininas. Busca-se aqui entender porque determinadas narrativas tornaram-se atemporais e clássicas, constituindo uma base para a construção de outras narrativas. Assim, além de um levantamento histórico da vida social feminina e discussão da construção narrativa do conto de fadas, o estudo está pautado em uma interpretação psicanalítica das obras participantes do corpus. 
ABSTRACT: this dissertation of master degree makes a interpretation of four young people literature`s work, but the focus is the female persona. We search to understand how some narratives became classics, and now they are the base for the construction to others narratives. Then, there is a history research from the women living and how the fairies tales are made, but the studies and interpretations of the corpus of this dissertation come from the psychology vision. 


\section{AGREDECIMENTOS:}

Apesar dessa dissertação de mestrado possuir apenas uma autora, ela não foi feita sozinha. Esse estudo teve a colaboração e participação de muitas pessoas, que vão desde meu orientador até minha família.

Agradeço ao professor doutor José Nicolau Gregorim Filho por me orientar nesse aprendizado, e não apenas o meu trabalho acadêmico, como também a ajudar a lidar com minhas ansiedades e dúvidas ao longo do mestrado.

Aos meus amigos e amigas de pós-graduação: muito obrigada por envolveremse comigo nesse caminho, que para mim, foi tão árduo quanto maravilhoso. Vocês estarão sempre guardados em um lugar muito especial das minhas lembranças, no qual faz jus todo o apoio que vocês me proporcionaram.

Obrigada Valter por nossas longas conversas sobre arquétipos, comportamentos sócio-culturais e diferenças entre homens e mulheres. À Tatiana Colla Argeiro, companheira de cursos e viagens durante o nosso aprendizado na literatura infantojuvenil, obrigada pelo bom-humor e disposição em ajudar-me nas minhas dificuldades e entraves. Muito obrigada, Camila Flessati, por ser minha amiga fiel, que sempre esteve ao meu lado apoiando e incentivando-me, que dividiu comigo diversas angústias, anseios e realizações nesses anos de estudos e amadurecimento pessoal.

Agradeço o apoio intelectual e pessoal de Christina Riego, amiga que fiz durante a graduação de Letras, construindo com ela uma amizade embasada não apenas nas afinidades intelectuais, como também, na forma de entender e posicionar-se na vida. Obrigada, também, à Tatiana Cabral Fernandes, colega de profissão e amiga; que muitas vezes ajudou-me no trabalho, dando-me assim mais tempo para me dedicar a escrita da dissertação.

Quanto à minha família, evidentemente me faltarão palavras para descrever com exatidão a importância deles nesse trabalho, pois eles sempre estiveram presentes e ativos na minha vida e no meu desenvolvimento acadêmico. Assim, agradeço ao meu irmão, Rodrigo, por ter paciência comigo e me ajudar com os trabalhos realizados no computador, nos quais ainda sou extremamente ignorante.

Aos meus pais, o agradecimento é maior, pois ambos estiveram muito presentes e sei que se sacrificaram para eu atingir meus sonhos e objetivos. Ao meu pai, Roberto, que também me auxiliou a entender e trabalhar com o computador, além do auxílio financeiro, para imprimir centenas de páginas de trabalhos e aquisições de livros; 
obrigada por sempre, de uma forma ou de outra, mostrar-se preocupado e orgulhoso com meu trabalho acadêmico. À minha mãe, Regina, faltam-me chances e gestos para agradecer tudo que fez por mim; já que foi a primeira a enxergar minha vocação profissional e ajudou-me muito neste caminho de estudos e aprimoramentos. Ela foi também minha primeira leitora e consultora nesse trabalho, quem muito auxiliou nas minhas reflexões, e esforçou-se ao máximo para esquecer que as linhas lidas eram escritas por sua filha, e assim fazer as críticas necessárias.

Agradeço Daniel Hernandes, meu companheiro de vida, que esteve presente durante todo esse processo de aprendizagem e amadurecimento acadêmico, e mantevese sempre solidário a mim, sabendo compreender meus momentos de mau-humor, de estresse e isolamento, além de compartilhar comigo as angústias e alegrias que esse trabalho trouxe para mim.

Por fim, agradeço a Deus, o ente superior que colocou diante de mim diversos desafios e escolhas, os quais me levaram até o caminho trilhado nesse estudo e aprendizado. Agradeço pela oportunidade de ter crescido e amadurecido nos campos profissional, acadêmico e pessoal, pois essa dissertação não gerou apenas um trabalho acadêmico, como também, levou-me ao maior autoconhecimento e compreensão do outro; aprendizado esse que repercutirá por minha vida adiante. 


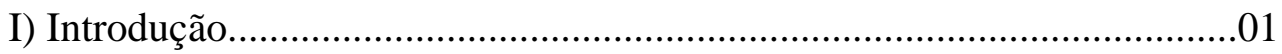

II) A tríade da arte literária: autor, personagem e leitor....................................04

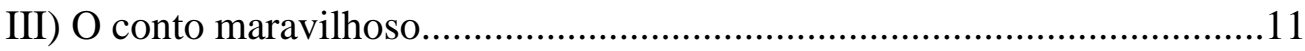

IV) Imagens da mulher: questões históricas..............................................20

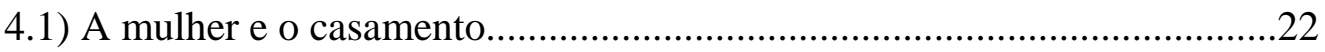

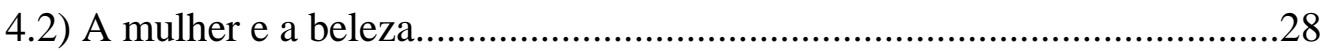

4.3) A mulher e a maternidade.................................................................33

V) Arte e ciência: o encontro da psicanálise com a literatura...............................36

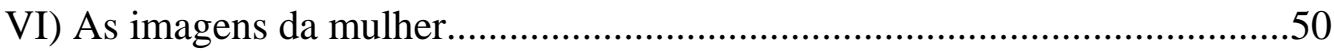

6.1) "Branca de Neve" compilada pelos irmãos Grimm..........................................50

6.2) "A mulher e a filha bonita" compilada por Sílvio Romero.............................65

6.3) "Rapunzel" compilada pelos irmãos Grimm................................................79

6.4) "A moça tecelã" de Marina Colasanti..............................................................90

VII) Considerações Finais.................................................................................101

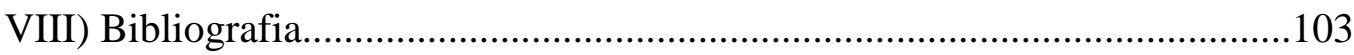

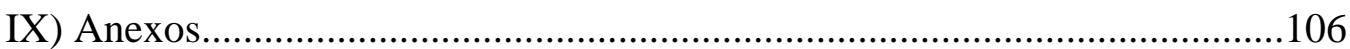




\section{I) INTRODUÇÃO.}

Durante a infância, minhas brincadeiras e imaginação viviam preenchidas com as personagens e as aventuras narradas pelos contos de fadas, sentia que aquele mundo, criado na ficção, fazia parte do meu. Encantava-me a possibilidade de ser uma princesa por baixo de roupas feias, superar os mais fortes e corajosos com minha sagacidade e esperteza, ou ainda, de descobrir-me a mais bela e graciosa após solucionar algum grande impasse da vida.

Porém, a idéia de pesquisar esse campo da arte literária, dirigida a um público mais jovem, que preencheu não apenas a minha infância, mas como a de todos que tenham tido o prazeroso contado com os contos de fadas, surgiu no ano de 2003, durante o curso de literatura infantil-juvenil, ministrado pelo professor doutor José Nicolau Gregorin Filho, no qual pude ter contato com essas obras de outra forma, lê-las com outra visão, com maior profundidade de análise; diferente das leituras feitas durante a infância ou adolescência, as quais havia somente um envolvimento emotivo com a obra.

O curso gerou uma série de questionamentos em relação à construção temática dos contos de fadas, se ela está ligada apenas à distração e divertimento de jovens leitores ou se está conectada com as tradições antigas orais de se contar estórias de costumes e crenças, que refletiriam o espírito humano em seus anos de formação e transformações até maturidade.

Outros fatores, que me encaminharam para este campo de estudo, foram minhas graduações universitárias. Primeiramente, formei-me em Pedagogia com especialização em ensino de deficientes mentais, ou seja, uma graduação focada na formação e desenvolvimento do ser humano em suas primeiras fases da vida. Posteriormente, a minha segunda graduação foi em Letras - português e alemão, na qual estudei não apenas as gramáticas ou as lingüísticas desses idiomas, como também, suas histórias, literaturas e culturas.

Assim, ao longo da minha vida acadêmica percebi que algumas construções temáticas literárias repetem-se, ou seja, certas estórias são narradas de diversas formas através dos séculos, culturas e sociedades. Dessa forma, propus-me a investigar quais seriam os temas que perduram na literatura infanto-juvenil e procurar entender as razões que os fazem serem tão revisitados. 
A minha linha de análise e reflexão investiga a obra literária não como um retrato, uma foto da realidade, mas uma visão estilizada, simbólica, psíquica e poética da humanidade e sua essência.

“Qualquer produção de idéias, que se distingue - ou talvez se oponha, mas jamais deriva (a não ser intuitivamente) - das produções materiais.”(PIERI, P. F. 2002: 233)

A realidade ficcional é capaz de extrair e expor, tanto de maneira lúdica como poética, as ambigüidades da vida, mediante os discursos das personagens, do narrador e do autor, a literatura tece em sua trama narrativa as diversas nuances e maneiras existentes de agir, sentir e absorver os impactos e experiências da vida. A ficção é um dos espaços artísticos que possibilita a união entre os indivíduos como seres passíveis de diversos sentimentos, conflitos, dilemas e desejos.

A Literatura pode ser ainda um espaço catártico, o qual nos afasta por um momento da nossa vida e realidade, e nos insere em outro mundo, dando-nos assim a possibilidade e vivenciarmos emoções que não teríamos chances de conhecer ou saborear na nossa própria existência.

Assim, seguindo essa linha de raciocínio, decidi analisar a figura feminina dentro do universo ficcional, como a mulher é representada e como seus anseios seriam correspondidos ou preenchidos com as personagens tão antigas e conhecidas da literatura infanto-juvenil. Dessa forma, selecionei dois contos compilados dos irmãos Grimm, Branca de Neve e Rapunzel, assim como narrativas mais atuais, como o conto compilado por Sílvio Romero - A Mulher e a Filha Bonita, e a narrativa da autora Marina Colassanti - A moça tecelã.

Esse corpus de análise dará vazão para a reflexão de como uma mulher pode ser representada, pois ele engloba não apenas épocas e culturas diferentes, como também apresenta diversos papéis femininos: mães, madrastas, filhas, irmãs e esposas. Ou seja, as narrativas selecionadas nos possibilitam enxergar algumas repetições temáticas aos longos dos anos e entendermos o porquê elas são tão revisitadas.

A dissertação procura levar em contar o maior número de fatores externos que podem exercer alguma relevância no processo criativo das obras, buscando explorar como o mundo ficcional relaciona-se com o real, e como isso pode manter o leitor tão 
envolvido e emocionado com a narrativa que ela acaba por atingir o status de cânone literário.

Reforço, então, que sendo essa uma dissertação na área de estudos comparados de literatura, a análise evidentemente levará em conta não apenas os aspectos literários e artísticos das obras, como também, os aspectos históricos, sociais e psicológicos envolvidos na construção narrativa, ou seja, a análise levará em conta as outras áreas do conhecimento acadêmico-científico, além do literário.

Ao longo da dissertação, separarei em capítulos as linhas teóricas que nortearão as análises reflexivas das narrativas literárias, pontuarei apenas os aspectos que interessam para tal. Dessa forma, pretendo explorar alguns matizes que colorem o universo da literatura infanto-juvenil, compreendendo sua importância tanto para os leitores como para a literatura universal. 


\title{
II) A TRÍADE DA ARTE LITERÁRIA: AUTOR, PERSONAGEM E
}

\section{LEITOR.}

\author{
"Através da arte \\ distanciamo-nos e ao mesmo tempo \\ aproximamo-nos da realidade." \\ Goethe.
}

O pensamento do grande poeta alemão, em epígrafe, não poderia refletir melhor as causas e finalidades do estudo literário, pois ele revela a dimensão de importância que a literatura tem em nossas vidas.

É por meio da literatura que podemos nos lançar a diferentes épocas, lugares e sentimentos. A literatura é uma arte que permite os seres humanos interagirem entre si por séculos, a perpetuarem sentimentos e descobrirem valores. Ela pode transmitir diversas emoções e continuar tocando seus leitores, independente do tempo em que vivem e da cultura na qual foram criados.

Independente do gênero literário com o qual o leitor esteja interagindo, pois a leitura é a interação do autor e sua obra com o leitor, a literatura sempre acrescentará à alma humana, transmitirá ou fará um julgamento de valor, uma nova percepção do mundo que nos rodeia, ou mesmo algo que corrobore nossos valores e sentimentos, a literatura sempre nos atingirá de uma forma ou de outra, podendo ser positiva ou não.

Ao mesmo tempo, que a literatura pode unir épocas e culturas distintas, ela pode também nos distanciar da realidade, ser uma fuga da vida cotidiana, uma alternativa de sonhos e esperanças. Ela pode nos apresentar ao mundo onde gostaríamos de viver, por meio dela podemos nos envolver numa vida que imaginamos ser mais saborosa, emocionante, justa, bela, surpreendente.

A literatura pode nos livrar daquele cotidiano massacrante ou ordinário, sem surpresas e levar as pessoas a um espaço onde possam viver e sentir experiências em seu interior que nunca teriam oportunidade de praticá-las na vida real. Ela é uma arte antecipatória que pode nos prever as conseqüências que ocorrem em determinados atos e ações, uma arte expurgatória ou catártica que nos faz realizar os desejos mais profundos e inconfessáveis do nosso ser.

Porém, como a literatura pode nos causar tantas emoções? Como ela nos toca tão profundamente, como nos envolvemos tanto a ponto de sentir o que está escrito? Evidente que há a excelência do autor, que nos tramite de forma magistral os 
sentimentos e valores que nos identificamos ou abominamos, entretanto como ele faz isso? O autor nos proporciona o deleite literário através de suas tão bem construídas personagens. As personagens são aquelas que proporcionarão toda a vivacidade e realidade que o autor deseja passar ao seu leitor, e o leitor será aquele fisgado ou entregue no mundo das personagem e do autor.

\begin{abstract}
“A ficção é um lugar ontológico privilegiado: lugar em que o homem pode viver e contemplar, através de personagens variadas, a plenitude da sua condição, e em que se torna transparente a si mesmo; lugar em que, transformando-se imaginariamente no outro, vivendo outros papéis e destacando-se de si mesmo, verifica, realiza e vive a sua condição fundamental de ser autoconsciente e livre, capaz de desdobrar-se, distanciar-se de si mesmo e de objetivar a sua própria situação.” (ROSENFELD, A. 2002:48)
\end{abstract}

Assim, as personagens serão aquelas que servirão de ponte entre o autor e o leitor, elas são os canais que darão vazão aos juízes de valores morais, culturais e emocionais, tanto para autores quanto para leitores. O autor se servirá das personagens para criar sua trama e transmitir tudo o que sua criatividade e espírito permitirem e desejarem; enquanto para o leitor, elas são seu caminho para adentrar um novo mundo, é sua forma de se identificar com algo que está além da sua vida, realizar sentimentos que procura e deseja vivê-los.

Isso é possível porque na literatura encontramos seres humanos com contornos de personalidade e caráter bem definidos, que ainda se mostram para nós, permitindonos ver que eles vivem quase como nós: estão em um mundo com valores intelectuais, morais, religiosos, políticos e sociais, e por tudo isso, eles tomam suas decisões, têm determinadas atitudes e enfrentam seus dilemas. Porém em determinado ponto eles terão algo que nós não temos, farão algo que não conseguiríamos ou resolverão seus problemas de forma surpreendentemente diferente da nossa.

Então, o autor que prende a atenção de seu leitor pode ser aquele que constrói suas personagens com algo de humano, algo em que realmente o leitor possa se conectar, independente da aparência da personagem, do local em que ela vive ou da época, ela deverá apresentar algo do espírito humano, algo que reflita nossa essência. Elas deverão de uma forma ou de outra vivenciar os nossos conflitos para poderem refletir em nós, para que haja o elo do artístico com a realidade.

"Muitas vezes debatem-se com a necessidade de decidir-se em face da colisão de valores, passam por terríveis conflitos e enfrentam situações-limite em que 
se revelam aspectos essenciais da vida humana: aspectos trágicos, sublimes, demoníacos, grotescos ou luminosos.” (ROSENFELD, A, 2002: 45)

A literatura então passa a ser uma arte libertadora e expiatória, ela apresenta os personagens em seus conflitos e resoluções que nos acalentam. A ficção nos une como humanos passíveis de diversos sentimentos, conflitos, dilemas e situações e nos mantém também afastados por um momento de nossa própria vida, medos, angústias e banalidades para vivermos através das personagens os nossos desejos.

Por isso, é tão importante que a personagem seja bem construída, seja o mais próximo possível do ser humano, pois é ela que poderá imortalizar e atravessar todas e quaisquer épocas e culturas, levando a estória da criatividade e talento do autor para os leitores mais variados e distintos.

Entretanto, isso não quer dizer que toda obra literária seja aquela que representa exatamente a vida, o mundo, a realidade exatamente como são. As personagens não devem ser simplesmente cópias de pessoas reais, a ficção exige verossimilhança e não relatos ou discrição da realidade, pois isso seria papel da História, do jornalismo e de outras instâncias de produção textual.

\footnotetext{
"Um acontecimento estético pode realizar-se apenas na presença de dois participantes, pressupõe duas consciências que não coincidem. Quando a personagem e o autor coincidem ou estão lado a lado diante de um valor comum ou frente a frente como inimigos, termina o acontecimento estético e começa o acontecimento ético que o substitui (o panfleto, o manifesto, o discurso acusatório, o discurso laudatório e de agradecimento, o insulto, a confissãorelatório, etc.) (BAKTHIN, M, 2003: 20)
}

Assim, para Bakhtin, uma obra literária com valor artístico, aquela que irá ultrapassar as barreiras sociais, culturais e temporais não pode apresentar apenas uma coesão entre as personagens e a narrativa, ela não é apenas um texto bem elaborado que desperta emoções, a obra ficcional de qualidade precisa ser construída mediante a realidade, porém ir além dela, revelar aquilo que os seres humanos temem ou angustiam-se, admiram ou desejam secretamente.

A personagem se faz tão vital à ficção, que Mikhail Bakhtin prende-se a uma compreensão mais detalhada sobre ela. Bakhtin discute a relação e importância da personagem para o autor em sua obra Estética da criação verbal, em que classifica três tipos gerais de personagens que o autor pode criar: a personagem assume o domínio sobre o autor, o autor se apossa da personagem e a personagem é autora de si mesma. 
No primeiro caso, a personagem tem personalidade e caráter tão elaborados e coesos que ela exerce uma determinada autoridade sobre o autor, tanto que este não consegue abandonar a maneira em que a personagem vê e vivencia o mundo, a personagem ganha tamanha dimensão que o autor não consegue mais, muitas vezes, distanciar-se dela para continuar construindo-a; o autor não consegue olhá-la de fora, como seu criador.

No segundo caso, o autor usa a personagem para transmitir todos seus pensamentos, ela torna-se um reflexo do autor, é a sua porta voz, aquela que irá dizer e fazer tudo que autor desejaria realizar em vida, porém de alguma forma é frustrado ou limitado. Não são personagens autobiográficas, mas é uma parte do autor inserida nela.

Enquanto que, no terceiro e último caso levantado por Bakhtin, a personagem é auto-suficiente e terminada de forma segura, ela surge pronta, plena, completa, como se ela representasse um papel dentro da ficção, como se ela possuísse uma determinada missão na narrativa, ela assim apreende sua própria construção estética.

Vemos que o autor ficcional precisa ter uma habilidade ímpar para criar e desenvolver suas personagens, para que estas não caiam em banalidades e trivialidades que as façam perder o valor artístico, arrastando a obra para outro campo de cunho não literário. Assim, as personagens precisam deixar transparecer os valores sócio-culturais e os artísticos também.

“É importante observar que não poderá apreender esteticamente a totalidade e plenitude de uma obra de arte ficcional, quem não for capaz de sentir vivamente todas as nuanças dos valores não- estéticos - religiosos, morais, político-sociais, vitais, hedonísticos etc. - que sempre estão em jogo onde se defrontam seres humanos.” (ROSENFELD, A, 2002: 46)

Portanto, para que o autor ficcional realize com sucesso sua obra, ele precisa definir uma visão para sua personagem, uma personalidade, mas ela não será aleatória, mas escolhida por determinadas qualidades, virtudes e atitudes para transmitir ou expor aquilo que se encontra dentro das vontades emocionais do autor.

É incorreto, todavia, tentar explicar as personagens pela vida do autor ou as circunstâncias em que escrevia, porém ele não irá escrever profunda, poética e esteticamente sobre eventos e vidas que lhe são totalmente alheias, distantes, ou seja, que não conheça ao menos. A literatura, para alcançar e tocar seus leitores, precisa ser verossímil, o autor não pode soar falso ou absurdo emocionalmente, ele escreve sobre 
algo que talvez nunca tenha vivido ou sentido, mas certamente outros seres humanos já passaram, assim ele deve ser verdadeiro com aquilo que expõe esteticamente.

Existem padrões e expectativas a serem cumpridos na ficção, o leitor aspira por certas emoções quando procura por determinada obra literária; assim quando um leitor busca uma ficção policial, ele deseja encontrar aventura, mistério, raciocínio lógico, entre outros elementos e não o dilema e problemas da protagonista em declarar e assumir o seu amor pelo filho do inimigo de seu pai. Então, o autor tem que se manter verdadeiro naquilo que se propôs, seja uma narrativa fantástica, uma fábula, romance, epopéia, poesia, qual for a estrutura narrativa deve-se seguir sua lógica interna, mantê-la coesa, ou seja, verdadeira.

\footnotetext{
"Assim, o leitor contempla e ao mesmo tempo vive as possibilidades humanas que a sua vida pessoal dificilmente lhe permite viver e contemplar, visto o desenvolvimento individual se caracterizar pela crescente redução de possibilidades.” (ROSENFELD, A, 2002: 46.)
}

A ficção permite ao leitor entender experiências vividas que não puderam ser contempladas no momento do envolvimento, permite a distância necessária para enxergar todas as nuances delicadas que envolvem os relacionamentos humanos e as conseqüências de determinados atos. Somente as personagens dão a oportunidades dos indivíduos vivenciarem o mundo, e não apenas apreender uma concepção através da leitura de uma obra filosófica.

Segundo Bakthin, o autor deve preencher sua personagem com os sentimentos, circunstâncias e objetos dos sentimentos do mundo concreto, pois estes são os tons da emoção; se o autor quiser, por exemplo, representar o sofrimento humano, ele deve vivenciá-lo esteticamente e depois concluí-lo na obra. Ele deve compenetrar-se no sentimento alheio, colocar-se no lugar do outro e tentar coincidir-se com o outro. O autor deve compor em um horizonte que seja concreto ao outro para que ele possa identificar e encontrar-se na obra.

A obra literária não é um retrato, uma foto da realidade, mas sim em visão estilizada, simbólica, psíquica e poética da humanidade e sua essência. É na realidade ficcional que ficam claras, expostas as ambigüidades da vida, através o discurso da personagem e do narrador, ou mesmo, do autor, mostrando as diferenças que podem existir na maneira de agir, sentir e absorver os impactos da vida. 
Outro estudioso, Todorov, também acredita que em dos elementos narrativos o mais importante na ficção é a personagem, pois são elas as caricaturas da vida, que concentram a psicologia, o pensamento e as atitudes, são as personagens que dão o colorido para a narrativa, pois são elas que demonstram as ideologias, idéias e formas de viver, pois é ela que apresenta um momento de sua vida na ficção. Assim toda personagem significa uma intriga, uma fonte de caracteres e psicologias descritas, ganhando vida na obra.

"Seria pois mais justo dizer que a causalidade psicológica reforça a causalidade das ações, do que dizer que ela não interfere nesta última. As ações se provocam umas às outras; e, por acréscimo, uma dupla causa-efeito psicológicos aparece, mas num plano diferente.” (TODOROV, T. 2004: 122.)

Nas artes literárias, a personagem realmente constitui a ficção, pois é para ela que toda a atenção está voltada, o narrador fica em segundo plano, enquanto que o autor nem é lembrado pelo leitor. Na ficção, o que importa é o estado da personagem, sua estória, seu mundo e realidade, é nela em que o leitor pretende se ligar, que deseja amar ou odiar.

A personagem é como um esquema das potencialidades humanas, um ser que guarda em si as sementes de diversos frutos que poderão vingar ou não. Ela é um esquema que contém várias projeções psíquicas reveladas durante a narrativa ficcional, podendo ser enxergadas ou não pelos leitores.

Então, a ficção é o único lugar em que ser humano pode tornar-se transparente a si mesmo, pois é na imaginação do autor que se unem as peças opacas e desalinhadas da realidade, através de sua estilística surgem personagens repletas de intenções, sem referências a outros seres autônomos, que são totalmente projetados em nossas mentes por palavras, dando assim espaço para enxergá-las conforme nossa interpretação.

Mesmo com esse espaço, o da interpretação pessoal, o leitor não pode e nem consegue afastar-se muito do autor, pois é esse o agente detentor do todo da obra, das personagens, é o único que conhece a totalidade desse mundo ficcional, ele é a consciência deste mundo, ele constrói a ética, a moral e cognitivo, a índole de cada personagem. Na ficção o autor guia um ser que ele mesmo criou por um caminho montado peça por peça por si próprio.

A tríade autor-personagem-leitor é uma estrutura muito delicada. Cada participante, de uma forma ou de outra, influencia, interfere ou contribui de alguma 
maneira com os outros participantes. E quando há uma conexão harmoniosa entre os três elementos da tríade, alcança-se a existência da obra artística literária. O movimento de um elemento reflete no outro instantaneamente, fazendo com que os elementos literários unam-se de forma perfeita e construam uma obra ficcional de tamanha qualidade que ela perpetuará pelos anos futuros. 


\section{III) O CONTO MARAVILHOSO.}

Primeiramente, é importante ressaltar que o conto maravilhoso é construído tanto por fórmulas míticas ou orais quanto pelo narrador escritor, ou seja, há nele elementos narrativos formais, aqueles de cunho literário, que seriam como um protocolo a serem cumpridos, como também elementos nascidos da fantasia e imaginário de uma sociedade e cultura, assim, há um equilíbrio no conto maravilhoso entre a criação e a realidade, fazendo dele uma obra artístico-literária.

Portanto, para entender e ter uma ampla visão do conto maravilhoso como estudioso do assunto, não somente como leitor, faz-se necessário explorar todas as vertentes e influências que penetram na narrativa. Não se pode estudar apenas um aspecto sem levar em consideração o todo, assim como não se pode analisar o todo sem considerar todos os aspectos envolvidos na construção da narrativa do conto maravilhoso.

"Para nós, o conto maravilhoso é uma totalidade em que todos os assuntos estão ligados e condicionados entre si. É justamente isso que torna impossível o estudo isolado de um motivo.” (PROPP,V, 2002: 05.)

Sendo uma narrativa oral passada de geração a geração, e posteriormente compilada em diversos países, por diferentes pesquisadores e escritores, o conto maravilhoso guarda em si diversos traços sócio-culturais que já desapareceram, foram modificados ou persistem com diferentes valores até hoje. Desta forma, é importante checarmos quais são as fronteiras históricas e quais as ficcionais do conto maravilhoso, para entendermos o seu todo.

Assim, é importante avaliar, segundo Propp, quais são os ritos das culturas e sociedades mais antigas e primitivas, pois muitos são descritos ou são simbolicamente representados na narrativa. O rito mais marcante para a sociedade e que debruçou maiores estudos para o pesquisador russo foi o rito de iniciação, aquele que marcava a passagem da infância para a vida adulta. Este é o mais recorrente nas narrativas, apresentando-se sob várias formas metafóricas, relevantes em todas as sociedades.

"Posteriormente, quando o rito começou a declinar, a opinião pública teve de se modificar. Os benefícios ligados ao ato de iniciação tornaram-se incompreensíveis, e a opinião pública, mudando de rumo, começou a condenar 
esse rito terrível. Foi nesse momento que surgiu o enredo. Enquanto o rito como tal existiu, não pôde haver contos sobre ele.” (PROPP, V, 2002: 88.)

Esta citação nos revela elementos muito interessantes. Primeiramente, quanto os elementos sócio-culturais influenciaram o conto maravilhoso, como também seu surgimento possa ser uma maneira de expurgamento de ritos e crenças cruéis e desnecessários. Uma forma de passar as angústias e questionamentos de uma fase ancestral humana de uma maneira mais sensata e racional, uma expressão artística e mais tarde, literária.

O rito faz parte da organização social, ele possui sentido dentro de uma cultura e realiza-se para proporcionar melhorias a um grupo, sempre em detrimento ao sofrimento ou sacrifício de alguns. Mas quando a realidade dessa organização social transforma-se e os sacrifícios não se fazem mais necessários, o rito perde seu sentido e migra para a imaginação coletiva. Ele permanece presente nas narrativas de sagas, contos e tradições populares de cada cultura.

Sendo assim, o estudioso russo estuda os diversos ritos incorporados nos contos maravilhosos, as ações narrativas que tiveram origem na história cultural dos povos. Para nosso grande folclorista Câmara Cascudo, os contos nunca tiveram a finalidade de embalar as crianças em seu sono, mas sim de passar para as gerações mais jovens o corpo de ensinamentos religiosos e sociais que rege a organização do grupo em que vivem.

E ainda, seguindo o folclorista brasileiro em suas análises, ele aponta que quanto maior o distanciamento temático dos contos em relação ao espiritual primitivo ou da unidade psicológica ancestral, maior será o número de elementos de prosa ou literariedade que serão adquiridos e desenvolvidos nas narrativas, proporcionando assim, entendimento a outros povos e culturas, ampliando o raio de alcance de universidade do conto.

O início do conto é construído com informações muito vagas de tempo e lugar, apresentando imediatamente a personagem central e sua família ou sua moradia e alguns hábitos, uma esfera ilusória de tranqüilidade e felicidade, pois logo no início da narrativa surgiram fatos que desdobraram na descoberta de alguma carência ou dano, gatilhos para o desenvolvimento do conto.

É exatamente nessa esfera em que tudo poderia continuar muito bem, que não está exatamente localizada e que de uma forma inesperada transforma-se em uma esfera 
problemática sem uma razão aparente, são estes os elementos que prendem o leitor, que o faz identificar-se com a narrativa ou querer entendê-las, saber como soluciona o dano ou carência apresentados.

As narrativas iniciam-se com elementos bem organizados, os quais levam a acreditar que mudanças ou outras realizações são desnecessárias. As personagens parecem ter seus desejos realizados ou de possuírem elementos que as já fariam felizes, entretanto é dentro dessas situações de comodidade e tranqüilidade que surge uma semente do desequilíbrio, algo estranho ou ruim acontecerá de forma repentina, e proporcionando o desenvolver de toda narrativa:

"Quem me dera ter uma filha branca como a neve, vermelha como o sangue e negra como o caixilho da janela! Pouco depois, deu a luz a uma filha (...) E, quando deu a luz à luz a criança, a rainha morreu." (GRIMM, J \& W, 2000: 358)

"Certo dia, a mulher estava contemplando o jardim da bruxa, através da janelinha, quando avistou um canteiro de belos rapúncios, tão verdinhos e parecendo tão frescos, que ela, que gostava muito daquela verdura, sentiu muita vontade de comê-la. Essa vontade foi aumentando de dia para dia, e, como sabia que seu desejo não poderia ser satisfeito, ela começou a emagrecer e empalidecer, (...)” (GRIMM, J \& W, 2000: 322)

"Uma vez havia uma mulher viúva que tinha uma filha muito bonita, e a mulher também era muito bela e tinha inveja da filha.” (ROMERO, S, 2005: 213)

"Nada lhe faltava. Na hora da fome tecia um lindo peixe, com cuidado de escamas. (...) Mas, tecendo e tecendo, ela própria trouxe o tempo em que se sentiu sozinha,(...)” (COLASANTI, M, 2004: 04)

Nesses exemplos, o desequilíbrio não é explicado, ele simplesmente surge inesperadamente, mas que nos desenrolar da narrativa fica claro que este desequilíbrio se faz necessário para o crescimento e fortaleza da protagonista, que apesar de haver explicações explícitas de seu surgimento, há no final uma justificação para tal, já que há uma redenção a protagonista.

Assim como no rito, o conto mostra que as transformações boas vêm de situações ruins. O rito existe não apenas para manter-se uma identidade cultural, como também para ensinar e preparar indivíduos de determinados grupos a viverem adequadamente em seu meio sócio-cultural. Geralmente, esses ritos são duros, cheios de sacrifícios e sofrimentos, e seus iniciantes não recebem explicações do porquê de estarem passando por aquilo, mas que ao término levam ao indivíduo a um status mais bem aceito pela comunidade em que vive. 
O conto maravilhoso é uma estória que segue certos padrões narrativos, pois mesmo surgido e difundido oralmente, ele segue elementos literários, é uma criação artística construída por meio de algumas fórmulas, mas sem perder o colorido ou ser simplista, ordinário, vulgar. Os contos possuem características que os unem em mesma categoria, como qualquer movimento artístico.

"Do ponto de vista morfológico podemos chamar de conto de magia todo desenvolvimento narrativo que, partindo de um dano (A) ou uma carência (a) e passando por funções intermediárias, termina com o casamento $\left(\mathrm{W}^{\circ}\right)$ ou outras funções utilizadas como desenlace. A função final pode ser a recompensa (F), a obtenção do objeto procurado ou, de modo geral, a reparação do dano (K), o salvamento da perseguição (Rs) etc.”(PROPP, V, 2002: 90)

O conto maravilhoso foi definido pelo folclorista russo Vladimir Propp em narrativas orais, mais tardes recolhidas ao cânone literário infanto-juvenil, que possuem grandezas constantes e grandezas variáveis. Ou seja, as narrativas possuem heróis ou heroínas com diferentes nomes e características físicas, mas com as mesmas ações e atitudes; as personagens desempenham as mesmas funções, independente de como a narrativa se desenrola. Assim, Propp estuda, classifica e analisa os contos maravilhosos a partir das funções desempenhadas pelas personagens.

Em seu estudo morfológico do conto maravilhoso, Propp conclui que há diversas personagens, porém poucas funções para tais, tornando, assim, o conto uma narrativa dualista, que por um lado possui uma grande diversidade de caracteres, mas por outro há uma uniformidade de ações, permitindo o estudo de diversas narrativas quaisquer que sejam a língua e época de origem.

"Por função compreende-se o procedimento de um personagem, definido do ponto de vista de sua importância para o desenrolar da ação.” (PROPP, V, 2002: 22)

Desta forma, não importa de qual forma a personagem executará determinada ação, mas sim que ela esteja presente na narrativa. De uma forma ou de outra, determinadas ações e atitudes estarão presentes no conto maravilhoso, pois elas serão seus elementos constantes e básicos, a identidade do conto maravilhoso.

Para nosso estudo, levantarei apenas algumas funções, aquelas que estão presentes no corpus delimitado no estudo, e não todas as existentes, já que apenas as que participam nos contos analisados nos são esclarecedoras e necessárias. As funções 
descritas e discutidas aqui são dos estudos de Propp, que exemplifica suas análises com contos russos, onde o herói, centro da narrativa, quase sempre é um homem, porém utilizando de suas próprias idéias em que não importa qual personagem faça a ação, mas apenas que ela seja desempenhada por alguém, analisaremos as personagens, as heroínas com as mesmas teses.

"O comportamento dos personagens no decorrer do conto é, na maior parte dos casos, motivado pelo próprio desenvolvimento da ação, e somente o advento do dano ou da carência, função primeira e fundamental do conto, exige motivação complementar.” (PROPP, V 2002: 73.)

Assim, se para a narrativa do conto maravilhoso ou mágico o importante são as ações desenvolvidas pelas personagens, o foco estará sempre na ação e não na personagem em si, mas nas suas atitudes. Por isso, as descrições de caráter das personagens sejam tão menores que as das armadilhas, fugas, descobertas e afazeres delas. As descrições mais detalhadas estão nas conseqüências dos atos e não dos sentimentos das personagens. Sendo assim, vejamos aqui, algumas ações temáticas levantadas e estudadas por Propp, que estão interligadas ao corpus analisado na presente dissertação:

a) o conto geralmente inicia-se com a apresentação da família da personagem central, sua casa e alguns hábitos, para, em seguida, surgirem as ações. Primeiramente, há o afastamento de um membro da família, que pode ocorrer com a morte de um dos pais ou ainda com a retirada de um dos filhos do lar, como um rapto ou pagamento de uma promessa;

b) há uma proibição à personagem central ou aos seus pais e esta é sempre transgredida e sucedida por um castigo, punição. Neste momento, dá-se a entrada da antagonista; por vezes, essa personagem já faz parte da narrativa, mas é nesta hora em que ela poderá demonstrar seu lado mal, contrastante com a da protagonista, inocente e bondosa. Dessa forma inicia-se a perseguição da antagonista contra a protagonista ou a captura e prisão da última pela primeira;

c) a antagonista começa a agir e criar situações em que possa obter informações da protagonista, e evidentemente para o desenvolvimento da narrativa, ela sempre obtém informações de sua vítima, e isto ocorrerá por interrogatórios, meios mágicos ou ao acaso; 
d) de posse sobre as informações da protagonista, do seu paradeiro ou de suas ações, a antagonista tenta ludibriá-la para obter o que deseja de sua vítima, seus bens. A antagonista irá se disfarçar, imitará a voz de uma pessoa de confiança da protagonista, usará de persuasão, meios mágicos ou fraude para alcançar a protagonista e tomar-lhe o que inveja;

e) a protagonista irá sempre deixar-se enganar e acabará realizando o desejo da antagonista, cedendo-lhe algo ou ajudando em alguma situação. A personagem central acaba por deixar-se seduzir ou persuadir pelos argumentos da antagonista, e provavelmente, neste momento, a protagonista mais uma vez quebre alguma proibição imposta a si, como não falar ou aceitar qualquer presente de estranhos;

f) mediante a falha da protagonista diante as artimanhas ou armadilhas da antagonista, há o dano ou prejuízo a um dos membros da família ou da própria protagonista. A antagonista faz exigências ou extorque a família da heroína ou a própria, o vilão expulsa a protagonista de seu lar no intuito de mandar prender ou matála. Quando a família da protagonista é extorquida, deve-se a alguma carência em que os membros buscam suprir e acabam por envolver-se com a antagonista, e realizando com ela um péssimo negócio;

g) muitas vezes, a antagonista surge diante de um dilema da protagonista, em que a heroína ou sua família buscam saciar alguma carência, desde ordem econômica até por desejos amorosos. A protagonista busca um casamento, um tesouro, poderes mágicos, um ente querido, objeto ou alimento incomum; algo que lhe de muita importância para a personagem, mas que terá diversas dificuldades em realizar seu desejo devido as interferências da antagonista;

h) após alguns embates com a antagonista, finalmente a protagonista vence, sendo recompensada. Todos os males causados pela antagonista são revertidos e ainda há algum prêmio especial para a protagonista que derrotou o mal. A heroína geralmente coloca a antagonista em uma situação que causa sua morte e termina com todos seus asseclas;

i) neste momento, a protagonista liberta-se do feitiço ou maldição lançados contra ela, chegando então a sua recompensa, a qual ela ressuscita, é libertada do cárcere, casa-se, fica rica, consegue poderes mágicos, reencontra seu amado ou ente querido, ou ainda, torna-se governante de um próspero e grande reino. O conto finalizase assim, com a protagonista bondosa eliminando a maléfica antagonista, tornando todos seus familiares gratos e felizes e ainda alcançando sua redenção e felicidade. 
Essas então são algumas das ações desempenhadas pelas personagens do conto maravilhoso, mais especificamente daquelas que estão presentes no corpus desse estudo. Porém, Propp ainda, distribuiu as funções entre as personagens, chamando-as de esferas de ações, o que discutiremos a seguir.

“(...),podemos indicar que numerosas funções se agrupam logicamente segundo determinadas esferas. Estas esferas correspondem, grosso modo, aos personagens que realizam as funções. São esferas de ação.” (PROPP, V, 2002: 77.)

Segundo este estudo, há sete esferas de ação nas quais as personagens distribuem-se e a narrativa toma seus rumos. São elas:

a) do antagonista (malfeitor): compreende o dano, as formas de luta e perseguição contra a protagonista;

b) do doador (provedor): compreende a transmissão de um objeto mágico ou respostas à protagonista;

c) do auxiliar: compreende o deslocamento espacial da protagonista, a reparação de um dano ou carência, o salvamento durante uma perseguição, a resolução de tarefas difíceis e a transfiguração da protagonista;

d) da princesa (personagem procurado): compreende a proposição de tarefas difíceis, a imposição de um estigma, o desmascaramento, o reconhecimento, o castigo do malfeitor e o casamento;

e) do mandante: compreende apenas o envio do herói;

f) herói: compreende a partida para realizar a procura, reação perante as exigências do doador, o casamento. Há, então, o herói buscador como também o herói vítima, conforme as circunstâncias,

g) falso herói: compreende também a partida para realizar a procura e reação perante as exigências do doador, como também, atitudes sempre negativas e pretensões enganosas.

Portanto, essas são as sete personagens básicas de um conto maravilhoso classificas por Propp, porém elas não são prerrogativas essências para que seja estruturada e definida essa narrativa. Muitas vezes, nem todas as sete personagens estarão participando da narrativa, mas suas funções e ações podem estar distribuídas entre poucas personagens; assim, o conto pode apresentar as funções e características acima descritas. 
O que é interessante refletir em nosso corpus é a função do herói e da princesa, pois nos estudos de Propp está embasado nos contos russos, que se diferem um pouco em relação aos contos alemães, as narrativas dos irmãos Grimm apresentam as funções e ações descritas anteriormente, mas com as personagens invertidas. Quem desempenha o papel de herói e realizador das mais importantes e maiores ações do enredo é a princesa ou a jovem vítima da malfeitora. São as mulheres que dão o ritmo da narrativa e não os homens, príncipes ou heróis, como nos contos russos.

Os príncipes ou heróis apresentados nos contos do corpus não desempenham funções de destaque, eles são quase personagens auxiliares, que dão uma pequena ajuda a heroína ou protagonista resolver seu problema, o dano causado pela antagonista. Os príncipes não são as personagens que saem de casa em busca de um casamento ou reverter algum dano ou carência, eles surgem no momento de proporcionar ajuda para a princesa ou de colocá-la em mais uma situação difícil, que adiantará o embate com o malfeitor.

As protagonistas só alcançam todos seus objetivos após encontrarem os príncipes, que vão até seus encontros. No momento em que há a união do casal, independente, se for ao acaso ou após uma longa e sofrida busca, as jovens realizam seus desejos ou libertam-se do cárcere ou maldições impostas pela antagonista.

As protagonistas são jovens mulheres que saem de casa ou são entregues e aprisionadas pelas antagonistas, e são elas que têm a função de buscarem além as fronteiras domésticas recompensas, bens e felicidade, ou ainda, são elas mesmas as responsáveis por se desvencilharem de um dano ou carência. Assim, os príncipes não são aqueles que resgatam as jovens dos perigos enfrentados, mas sim a recompensa por elas terem ultrapassado todas as dificuldades.

Porém, essas diferenças não modificam a natureza do conto e muito menos surpreendem ou vão contra os estudos de Propp, já que ele mesmo escreve que: Mas os contos dos irmãos Grimm, que seguem em geral o mesmo esquema, apresentam já um aspecto menos puro e menos constante desse esquema. Não é possível prever todos os detalhes.”(PROPP, V, 2002: 98.)

Para o estudioso, os contos são originados mais provavelmente de mitos passados oralmente geração após geração e sendo influenciados e transformados pelos seus narradores, tempo, espaço e cultura; pois tudo pode influenciar uma narrativa oral. Deste modo, Propp considera alguns contos mais puros que outros, os que apresentam o maior número de funções e características por ele levantados, são os mais puros, 
enquanto que aqueles que possuem uma construção narrativa diversa, estes são menos puros.

"Dizer "fonte única” não significa, absolutamente, que os contos surgiram, por exemplo, na Índia, e que dali se alastraram pelo mundo todo, tomando formas diferentes no decorrer de suas viagens, conforme admitem alguns. A fonte única pode ser também psicológica, no aspecto histórico-social.” (PROPP, V, 2002: 105.)

Os contos maravilhosos não têm uma fonte certa e única, apesar das semelhanças de formas e temas. Não há uma origem exclusiva para todos; a fonte de sua origem são diversos fatores que a humanidade divide entre si, compreendidos por todos seres humanos. O conto reflete a realidade, o cotidiano em uma escala bem mais reduzida, mas que ainda diz muito a respeito às pessoas; em formas psicológicas, históricas, sociais e culturais.

Para o nosso estudo, a fonte de origem dos contos não é o que mais nos aflige, e que caso fossem determinadas não nos traria as respostas mais reveladoras e satisfatórias. Entretanto, ao momento que se enfoca determinados elementos e se busca como são construídos e desenvolvidos, temos as respostas e o entendimento que suplantam a importância da sua origem.

Quais são os reflexos da realidade e quais os elementos literários das personagens, em particular no recorte aqui feito, as femininas, o que as mantém tão vivas na imaginação de tantos leitores ao longo de séculos?

Essas questões serão discutidas no decorrer da dissertação, mas o importante a se dizer agora é que, independente de quais elementos os contos maravilhosos apresentem, haverá sempre um presente, aquele que é obrigatório neste tipo de narrativa, o dano ou a carência. Este elemento sempre estará presente no início da narrativa e será o primeiro nó narrativo ao qual as personagens deverão desenvolver suas ações, que dará a partida ao enredo.

O dano ou carência são o recurso narrativo essencial para que a trama do conto se desenvolva, é a partir deles que a personagem central buscará a reparação, gerando todos os conflitos e situações narrativas. Entre o dano ou carência iniciais até reparação final existe uma separação, na qual o narrador mostrará diversos nós narrativos e os desenvolverá, dando as tonalidades, o colorido a trama.

O conto maravilhoso é uma estória que segue certos padrões narrativos. Mesmo surgido e difundido oralmente, é uma criação artística que segue algumas fórmulas, mas 
sem perder o colorido e a natureza simplista, ordinária ou vulgar. Os contos possuem características que os unem em uma mesma categoria, como qualquer movimento artístico.

Tais características concentram-se nas ações das personagens, todo o desenrolar narrativo está focado nelas, assim não importa de que forma a personagem executará determinada ação, mas sim que ela esteja presente na narrativa. De uma forma ou de outra, determinadas ações e atitudes estarão presentes no conto maravilhoso, pois elas serão seus elementos constantes e básicos, a identidade do conto maravilhoso.

Para a narrativa do conto maravilhoso ou mágico, o importante são as ações desenvolvidas pelas personagens, o foco estará sempre na ação e não na personagem em si, mas nas suas atitudes. Por isso, a descrição de caráter das personagens é tão menor se comparada às armadilhas, fugas, descobertas e afazeres delas. As descrições mais detalhadas são das conseqüências dos atos e não dos sentimentos das personagens.

Tanto o conto maravilhoso como o conto de fadas pertencem ao mesmo universo: o dos fatos maravilhosos, do onírico, ou seja, ambos podem apresentar animais falantes, reis e rainhas, bruxas ou duendes, metamorfoses, eventos mágicos, tempo e espaço não definidos com exatidão. O conto maravilhoso, mágico ou de fada não se distinguem na forma ou temática, pois tratam sempre da realização do herói, da protagonista.

Independente da classificação usada, conto de fada ou maravilhoso, essas narrativas tratam e expressam as atitudes humanas que podem ser bem diferentes diante da vida, mostrando como os indivíduos buscam e alcançam sua auto-realização mediante a superação de obstáculos do cotidiano e o amadurecimento diante as dificuldades e revezes do destino. 


\section{IV) IMAGENS DE MULHER: QUESTÕES HISTÓRICAS.}

Este capítulo procura esclarecer as ligações femininas históricas, sociais e culturais com a narrativa ficcional, em nosso caso, com o conto de fadas. O quanto as mulheres estão envolvidas verdadeiramente na construção das personagens, não como autoras, mas como fonte de inspiração ou mesmo modelo. Quanto há refletido da natureza feminina na ficção, se a construção da imagem da mulher é coerente com a realidade e cotidiano femininos, ou se as personagens são apenas imagens distorcidas, construídas para atender expectativas sociais e corroborar certos comportamentos.

Para tanto, faz-se necessário entender como as relações sociais e pessoais podem interferir na construção histórica da mulher e como as expectativas masculinas recaem e repercutem na vida da mulher. Como os papéis de filha, esposa e mãe foram modificando ao longo dos séculos XVII a XIX e quais foram as implicações dessas mudanças. A importância da reflexão sobre o conceito de beleza feminina e a questão do aborto.

Primeiramente, é importante esclarecer que a história não é única e uniforme a todos, ou seja, o percurso histórico evolui de formas muito diversas conforme os agentes que dela participam. A história não é uma ciência imparcial em relação a sexo, crenças e status social, seu estudo consiste em agrupar seres humanos em determinadas épocas e recuperar e entender como a espécie humana viveu; porém veremos que, embora a época, a cultura e o território sejam compartilhados pelos seres humanos, eles raramente compartilham todos os mesmos sofrimentos ou regalias, os mesmos conflitos ou evoluções.

Para entendermos com profundidade a mulher que é construída na literatura, não podemos deixar de rever sua história, sua trajetória na sociedade. É necessário entendermos quais caminhos percorridos pelas mulheres ao longo dos séculos, quais foram seus problemas e suas lutas, quais foram as mudanças ocorridas em suas vida social, econômica e privada. Portanto, é necessário entendermos o quanto de sua história real refletiu e afetou a ficção.

Por isso, a necessidade de se estudar separadamente a história da mulher, o como e o porquê ela evolui, alcançou e ocupou os espaços no mundo e desempenhou certos papéis e foi renegada a outros, qual sua forma de adaptar-se ao mundo e como foi vista ao longo das épocas, não só pelos homens como também por suas iguais. Para tanto, 
meu enfoque será feito na mulher medieval à mulher da idade moderna, já que estes são os períodos pertinentes a este estudo.

\section{1- A mulher e o casamento.}

As mulheres não casavam tão precocemente quanto se pensa hoje em dia. No início do renascimento, as meninas de classe baixa saíam de casa muito cedo, em média com doze anos, não para casarem, mas para trabalharem e juntar posses - dinheiro para seu dote. Essas meninas trabalhavam por volta de quinze anos e retornavam a terra de origem com suas economias para só então casarem, ou seja, a média de idade para o casamento na população mais baixa girava em torno dos vinte e seis anos. Entretanto, quando a economia estava melhor, e os empregos eram mais abundantes, as moças conseguiam juntar dinheiro rapidamente e a média de idade para o casamento caiu para os vinte e três anos.

\footnotetext{
“Os dados que conhecemos para a Holanda sugerem igualmente que a prosperidade predominante no século XVII favoreceu casamentos mais precoces, enquanto que a situação mais difícil da agricultura e a depressão industrial verificadas na segunda metade do século XVIII conduziram a casamentos mais tardios e a um aumento do celibato definitivo.” (HUFTON,O.1991: volume 3-43.)
}

Porém, mesmo em tempos de estabilidade econômica, muitas mulheres ficavam sem casar, não porque não havia homens para tal, mas porque não haviam juntado dinheiro suficiente para o dote. Mesmo as moças de famílias mais nobres permaneciam solteiras, já que cada família conseguia casar somente uma ou no máximo duas filhas, sem depauperar os bens familiares.

O casamento só ocorria se a mulher pudesse contribuir economicamente para a vida de um homem, tanto que os homens de classe média poderiam casar com uma trabalhadora remediada, já o contrário não ocorria, pois seria uma vergonha para a família da noiva, uma mulher de classe superior casando-se com um homem de classe inferior, as mulheres só podiam se casar com seus iguais, enquanto os homens eram livres para se casarem com quem lhes fossem mais interessantes, mesmo que a candidata fosse de status social inferior aos deles.

Em tempos difíceis, a instituição do casamento era uma maneira de se viver melhor, já que as mulheres não possuíam muitas opções de empregos e ascensão 
econômica, já que todos seus bens eram controlados por homens, sejam eles seus pais, irmãos, patrões ou maridos. Mesmo trabalhando por um salário, as mulheres não tinham total acesso ao seu próprio dinheiro, este sempre ficava guardado com seu patrão que o entregaria assim que ela precisasse ou mudasse de emprego. Quando não trabalhavam, quem administrava seu dote, evidentemente, era seu pai, e na falta deste, o homem responsável pela família, irmão, tio ou avô.

\begin{abstract}
"O casamento não era visto apenas como um destino natural da mulher, mas como um agente específico de uma metamorfose que transformava a mulher num ser econômico e social diferente enquanto parte de um novo agregado familiar, a unidade primária sobre a qual se baseava toda a sociedade. A função do seu marido era proporcionar-lhe abrigo e sustento. Ele pagava os impostos e representava o agregado na comunidade. O papel da mulher era o de companheira e de mãe.” (HUFTON,O.1991: volume 3- 48.)
\end{abstract}

Pode-se ver que o casamento, nos primeiros séculos do renascimento, dava-se principalmente por motivos financeiros e conveniência social. A união era vista como um negócio que deveria impulsionar a vida econômica do homem e para a mulher darlhe segurança e estabilidade. Evidente que nesta união em ambas as partes procuravamse para ter melhorias na vida social, o amor não era um fator de peso ou sequer cogitado, isso começa a mudar a partir dos séculos XVI e XVII.

Nesses séculos, há uma grande difusão do conceito de amor romântico devido à literatura trovadoresca, graças à imprensa e à alfabetização. Tal conceito inspirou a poesia, o teatro e as novelas e acabou concretizando-se em uma exigência social na vida real em meados do século XVIII. Além das idéias inspiradoras literárias, a economia começou a melhorar, e os jovens começam a ter uma independência financeira de seus pais muito mais cedo, e conseqüentemente não os fazia enxergar o casamento como apenas uma forma de viver mais amenamente em tempos difíceis, mas como a união entre duas pessoas que se amavam verdadeiramente.

Entretanto o encontro de almas, que poderiam se amar verdadeiramente, só aconteceria se houvessem oportunidades para que os jovens pudessem conhecer-se, conviver e apaixonarem-se. Surgiria, assim, na Europa práticas de encontros ou namoros, permitidos pelas famílias das classes mais baixas, nas quais os casais pudessem trocar intimidades e ter certas experiências sexuais, chegando mesmo a uma coabitação; porém o casal nunca chegaria a uma situação de gravidez. Ou seja, o 
namoro era um relacionamento em que o jovem casal pudesse passar noites juntos conversando e trocando carícias, mas que nunca chegariam a concretizar o ato sexual.

"Conhecidas na Inglaterra pelo nome de bundling e em França pelo de maraîchinage, albergement ou créantailles, várias formas, autorizadas pelos pais, de amores pré-nupciais, de experimentação sexual e mesmo coabitação ficaram documentadas por toda a Europa.” (GRIECO, S.1991: volume 3- 96.)

Tal prática permitia que os casamentos futuros fossem baseados em afeto e atração sexual e não apenas em comodidade econômica, já que o casal tinha não só a oportunidade de explorarem sexualmente seus corpos, mas também conhecerem com uma maior profundidade o caráter, o pensamento e gênio de seu parceiro. Caso houvesse afinidades no casal, haveria um casamento bem sucedido; caso contrário, cada um procuraria outro parceiro sem terem passado pelas experiências ruins de uma gravidez indesejada ou um casamento malfadado.

Entretanto, houve uma mudança também nas classes mais altas da sociedade para que o casamento chegasse à nossa concepção atual. Tal mudança ocorreu no século XVIII, mais tarde que a iniciada nas classes mais baixas, em que o casamento deveria não apenas igualitário social e economicamente como também deveria basear-se no compartilhamento de afeto e compatibilidade sexual; sendo que os maridos deveriam ser companheiros de suas esposas. Assim, as aventuras sexuais ou uma vida dupla com amantes e prostitutas não seriam mais perdoadas

As mulheres das classes mais altas mantinham amantes desde que cumprissem com seus deveres matrimoniais, dando ao seu esposo um herdeiro legítimo do sexo masculino, mesmo porque os homens das elites não estavam mais dispostos a arriscarem suas vidas em duelos por suas honras e muitas vezes poderiam ser favorecidos econômica e socialmente com casos extras conjugais de suas esposas. No final do século XVIII, na Inglaterra, uma das piores conseqüências do adultério feminino era a pesada compensação a ser paga pelo amante ao marido ofendido.

No século XIX, os relacionamentos pré-nupciais continuam dúbios se houver comparações entre classes sociais. Nas classes mais humildes e médias, a sexualidade é mais explorada, enquanto nas classes altas e aristocráticas, o puritanismo, principalmente o feminino, é rigorosamente exigido. 
"Uma jovem bem educada mantém a camisa vestida para se lavar, mesmo para tomar banho; para mudar de camisa fecha os olhos.” (KNIBIEHLER, Y.1991: volume 4- 368.)

"Nos Morais da Vendeia, os apaixonados, abrigados por um enorme guardachuva, entregavam-se a contactos tolerados pelas famílias: beijos prolongados, masturbação recíproca; as raparigas têm a curiosidade de experimentar vários namorados.” (KNIBIEHLER, Y.1991: volume 4- 369.)

As mulheres, portanto, continuam dependendo de muitos fatores externos para determinarem não apenas sua sexualidade, como também, quais seriam as expectativas que deveriam construir em relação a seu futuro companheiro. De um lado da sociedade, encontram-se moças que ignoram totalmente seus corpos e lutam contra seus desejos sensuais; de outro, moças que descobriam por si mesmas e já sabiam então exatamente o que a estariam esperando depois do casamento.

Vemos, desde o século XVII, que o sexo é um assunto muito difícil de ser tratado, um tabu, assunto esse que as famílias preferiam manter suas filhas totalmente desinformadas, na esperança de não fazer nascer nenhum desejo e manter suas virgindades, que funcionaria como prenda para o futuro marido. Sabendo-se que era muito difícil de refrear os impulsos sensuais, permitiam que suas filhas explorassem alguns aspectos da vida sexualmente ativa, porém sem grandes explicações ou reflexões a respeito.

Durante o século XIX, período do Iluminismo, houve também algumas mudanças no relacionamento entre pais e filhas, que refletiria no futuro casamento das moças da época. Os homens tornaram-se mais sensíveis e compreensíveis com suas herdeiras, criando novos laços afetivos dentro do lar. As meninas procuravam a estima do dono da casa, buscando agradá-lo de todas as formas, e o pai, um homem ocupado, faz uso dessa amabilidade em seu favor, designando várias tarefas administrativas à suas filhas. Tal envolvimento entre pais e filhas não era uma forma apenas para construção de vínculos, como também uma preparação para o casamento e vida econômica futura.

Essa relação às vezes não passava de mais uma forma de exploração feminina e caminhamento para o conformismo em que os homens são as pessoas importantes e que devem ser beneficiados com os esforços das mulheres, mesmo em detrimento de suas vontades.

"Mas é freqüente que essa colaboração se assemelhe simplesmente a uma exploração: a jovem serve de copista ou de secretária não remunerada, sem 
esperança de promoção. Do mesmo modo, é freqüente a jovem camponesa ter de "ajudar" o pai até os limites de suas forças. E em todos os meios sociais se espera que a filha seja a enfermeira do autor dos seus dias na velhice" (KNIBIEHLER, Y.1991: volume 4- 389.)

Sendo com laços emocionais estreitados ou com diversas vantagens garantidas aos homens, que ensinam às futuras esposas a serem mulheres obedientes $\mathrm{e}$ trabalhadoras, o relacionamento entre pais e filhas criou outro tipo de impacto sobre a instituição do casamento. As jovens mostravam-se muitas vezes, além de dóceis e mais subordinadas que os filhos, também competentes, fazendo-se muito difícil ao pai abrir mão de tal ajudante e companheira para entregar-lhe em casamento a outro homem, que teria então todos seus serviços e cuidados prestimosos.

Com maior integração da filha com seu pai e seus negócios, nascera uma certa liberdade de diálogo, deixando as moças à vontade para persuadirem e discutirem quais seriam suas opções de futuro, com quem gostariam de contrair matrimônio ou se iriam matricular-se em uma universidade:

"A partir do momento que a jovem manifesta o seu desejo de emancipação, estalam os conflitos. Por exemplo, a propósito da escolha de um marido: porque os pais mais liberais (em política) renunciam com dificuldade ao compromisso das suas filhas. (...) Outro conflito pode surgir quando a filha quer empreender estudos superiores em vez de se votar à vida doméstica." (KNIBIEHLER, Y.1991: volume 4 -390.)

No século XIX, portanto, já não há mais imposições de maridos às filhas, há alguma liberdade de escolha entre vários partidos, guardadas as diferenças sociais, transformando o casamento na união de um casal que possuíam ao menos afinidades ou objetivos comuns. Agora, o conceito de casal estava no início de sua construção, já que no momento em que a mulher pode manifestar suas preferências ou suas escolhas, ela possui então uma opinião, uma voz dentro do lar, ou seja, na vida do casal.

"Esposa, mãe, educadora, a mulher merece tantas atenções e respeito quanto o homem produtor de bens e provedor de fundos. O seu domínio não tem, de resto, limites: em nome da sua responsabilidade moral, ela vela pela virtude de todos os seus, intervém em qualquer parte onde essa virtude esteja em perigo. $\mathrm{O}$ marido aceita observações, mesmo sobre sua própria conduta.” (KNIBIEHLER, Y.1991: volume 4-394.)

Quando o divórcio torna-se legal na França, em 1884, a maioria dos pedidos parte das próprias mulheres desapontadas com a vida matrimonial, não pelas amantes 
que seus companheiros poderiam manter, mas alegando que não poderiam mais viver sob maus tratos, abusos e a falta de recursos, quando o companheiro revelava-se um grande boêmio.

Outro fator que pesou e trouxe mudanças ao casamento foi a Revolução Industrial, o avanço do capitalismo e mercado de consumo, trazendo mudanças econômicas que fizeram a mulher acumular o trabalho doméstico com o rentável para ajudar na manutenção dos bens familiares. Entretanto, a chegada da mulher no mercado de trabalho capitalista não significa que ela seria mais respeitada e possuiria os mesmos direitos dos homens. A mulher continua sendo vista a sombra do homem, seu salário é apenas um complemento do marido ou outros homens da família, portanto ela deveria ganhar bem menos que os homens, pois estes que deveriam ter ganhos que paguem seu trabalho e as necessidades de sua família.

\begin{abstract}
“(...) o salário de um homem tinha de ser suficiente não só para sua própria subsistência mas também para manter uma família,(...)Pelo contrário, do salário de uma esposa, $<<$ tendo em conta a atenção que necessariamente tinha de dar aos filhos, não se esperava mais do que o suficiente para seu próprio sustento>>."(KNIBIEHLER, Y.1991: volume 4- 456.)
\end{abstract}

Tal economia que desvalorizava o trabalho feminino, juntamente com o desuso do dote pecuniário, deixava as mulheres das classes mais baixas e médias em frente a complicações no campo matrimonial, que lhes fugia às mãos. Não há como acumular um dote, sendo tão mal remunerada, não há mais tanto tempo para despojar em namoricos e escolhas de pretendes, quando se precisa ajudar nas finanças domésticas. Assim, com sua força de trabalho tão mal paga, as mulheres estavam sempre à mercê de algum homem, independente de qual seria seu laço familiar com ele, pois nesse determinado ponto histórico os homens foram a única opção de sustento econômico e status social para uma mulher.

\begin{abstract}
“(...) que o amor vem depois do casamento. Se não vem, passam sem ele: o casamento é para elas a aquisição de uma identidade social, bem mais do que uma fonte de felicidade afectiva. Mas a idéia que se faz do dote começa a evoluir: apreciam-se cada vez mais as qualidades, os saberes, a habilidade que permitirão à futura esposa ser útil ao marido.” (KNIBIEHLER, Y.1991: volume 4- 392.)
\end{abstract}

As mulheres vêem que a vida torna-se cada vez mais exigente para com elas, que para tornar-se uma boa esposa não bastava ser carinhosa, atraente ou ter algum dinheiro 
reservado, mas elas teriam que se mostrar dispostas a trabalhar arduamente em um mercado econômico machista, e ainda serem inteligentes e habilidosas na gerência do lar e negócios familiares. Assim, teriam uma chance de conquistar uma posição social melhor da casa paterna e escapar da angústia de viverem sozinhas com os poucos recursos ou alternativas que a sociedade lhes proporcionava.

Desta forma, ao final da Idade Moderna, assistiu-se a uma melhoria na educação das jovens burguesas concomitantemente com a ausência de perspectivas profissionais para as mulheres, que dependiam somente de suas famílias para manterem-se economicamente; estas mulheres muitas vezes foram impelidas a tornam-se amantes por profissão, pois eram tão belas, elegantes e educadas, que podiam ser exibidas em público para deleite de seu amante de momento.

As transformações de maior peso no final da Idade Moderna nos relacionamentos pessoais, como o namoro e o casamento, deram às mulheres casadas outros papéis a serem desempenhados, aqueles que eram apenas exercidos pelas amantes e prostitutas. As mulheres poderiam não só dar prazer aos seus maridos, mas como também poderiam tê-lo. Com o afrouxamento das regras da sensualidade pré e até extra-nupcial, as mulheres puderam buscar não só amantes, mas sim satisfação e domínio de seu próprio corpo, entretanto a maior e mais importante mudança foi a conciliação desses três elementos: amor, sexo e casamento.

O que fica delimitado no século XIX é que a felicidade da mulher é construída com o marido, pois uma mulher bem tratada e respeitada em casa era considerada feliz. A mulher realizada é aquela que se adaptou ao marido, buscou crescer junto dele, almejou os mesmos sonhos e objetivos, conquistando-os junto com seu companheiro. Onde há, não apenas afinidades sentimentais, como também uma solidariedade econômica há um estreitamento de laços entre os cônjuges.

\section{2- A Mulher e a Beleza.}

Durante a Idade Média, a beleza feminina foi reprovada e temida pela cultura imposta pela Igreja Católica, já que esse atributo poderia desencaminhar e arruinar muitos bons homens. Com o renascimento, essa visão foi deixada de lado e um novo valor foi atribuído à beleza feminina. Neste novo valor, há o reconhecimento da beleza como sinal exterior e visível da bondade e boa índole que estão no interior da pessoa, 
que são invisíveis. A fealdade era associada tanto à inferioridade de caráter como à social.

A beleza tornar-se então um atributo necessário para comprovar seu caráter e integridade moral, como também comprovar seu status social, já que os pobres e prostitutas tornavam-se feios, corrompidos pelas suas sarnas e chagas de sífilis, enquanto que os nobres permaneciam intactos, belos.

A beleza feminina foi usada como um codificador, ou melhor, um indicador de todas as qualidades de caráter da mulher. Portanto, a mulher deveria demonstrar sua toda sua virtuosidade na aparência para assim que os olhos do cavalheiro posassem nela, não houvesse dúvidas sobre sua essência, o homem deveria reconhecer imediatamente a virtuosa mulher que ali se encontrava.

Assim, as mulheres dispunham grande parte de seu tempo e energia para alcançar a aparência que seguisse os padrões de beleza determinados culturalmente durante alguns séculos: uma face de pele clara, cabelo loiro, lábios vermelhos, bochechas rosadas e sobrancelhas pretas; enquanto ao resto do corpo da mulher, além de ter pele muito alva, deveria ser delicada, ter pés pequenos, mãos e pescoço esguios, seios firmes e redondos.

"A beleza seguia um determinado modelo, e as mulheres entregavam-se a grandes cuidados e despesas para que sua aparência se adequasse aos padrões, que se mantiveram praticamente inalterados nos primeiros tempos da Idade Moderna.” (GRIECO, S. 1991: volume 3- 85.)

Por meio da tradição oral e literária surgiram verdadeiros manuais de beleza, para que as mulheres pudessem adequar-se aos padrões vigentes, dizeres que exaltavam os espartilhos, os sapatos de saltos altos, os cosméticos, perfumes, etc. Evidente que nem todas as mulheres nasciam ou alcançavam os padrões estéticos, para estas, a indicação dada pelos manuais femininos, era que somente restavam-lhes esconder seus defeitos; como por exemplo, as baixas deveriam passar a maior parte do tempo sentadas e as com pés mal feitos, deveriam usar saias mais longas.

Entre tantos atributos, o que exerce maior fascínio aos homens, talvez até hoje, são os cabelos de uma mulher, tanto que ele é tratado como o maior trunfo de sedução das mulheres, tanto que em cultos religiosos as mulheres deveriam cobrir suas cabeças com véus e as freiras deveriam também esconder suas cabeças em hábitos, pois os 
cabelos deveriam ser exibidos apenas em lugares adequados e para determinadas pessoas.

No século XVIII, as diferenças estéticas entre homens e mulheres começam a acentuar-se, isso para a mulher implica em uma construção de imagem que deixe em foco todos seus atributos ou sinais identificados somente pertencentes ao feminino. Assim, os cabelos das mulheres seriam longos, bem tratados e penteados, pois eles são o maior diferencial entre homens e mulheres, já que as vestimentas permitiam que as mulheres mostrassem algumas formas de seus corpos que fossem diferentes das dos homens.

O cabelo seria o ponto de partida do jogo da sedução, pois ele é um elemento que pode ser ostentado sem que a mulher corra o risco de tornar-se vulgar, é por meio dele que a mulher demonstra toda sua feminilidade. Em público, ele será mostrado em diversos penteados; porém, à noite, a esposa o deixará solto para o seu marido, já que este é o único homem que pode ter esse privilégio - ver os cabelos de uma mulher soltos.

Esta parte do corpo ainda é tratada com muito cuidado no século XIX, já que o cabelo não é lavado, por receios de contrair resfriados, mas também porque acreditava que seu cheiro perturbava os homens. O cabelo ainda tem uma grande função de destaque; porque, assim como o vestuário, ele também explicitava conforme seu penteado a fase da vida em que se encontrava a jovem. O cabelo pode ser um aliado tão grande na arte de seduzir neste século, que as camponesas mais necessitadas podiam cortar e vender os seus, que seriam usados na confecção de cabelos postiços para elaboração de diversos penteados da moda.

"A saia da menina vai até o chão e o seu penteado é elaborado. A adolescente que atravessa a crise pubertária entrança os cabelos ou aperta-os numa rede, a saia vai até o tornozelo. A rapariguinha, antes da idade da razão, usa os cabelos soltos; o seu vestido deixa ver as botinas e mesmo as calças interiores.” (KNIBIEHLER, Y. 1991: volume 4-355.)

No século XIX, aumenta-se a necessidade de destacar as diferenças entre homens e mulheres, fazendo com que as mulheres dediquem-se cada vez mais à sua aparência. Em outras palavras, as mulheres buscam valorizar tanto tudo que fosse relacionado à sensibilidade e delicadeza, quanto às funções naturais de uma boa reprodutora, características essas não só consideradas próprias das mulheres, como também muito importantes: "O espartilho permite manter a finura da cinta e realçar 
peito e ancas, que aludem à função reprodutora” (KNIBIEHLER, Y. 1991: volume 4-353.)

As mulheres continuam buscando a perfeição estética, usando todos os artifícios necessários para destacarem-se das outras; assim não medem esforços para atingir os ideais de beleza difundidos pelos folhetins, que eram escritos por homens. Mantinha-se a pele o mais alva possível para mostrar-se uma mulher caseira, que era casta e decente, assim como o corpo deveria mostrar sua boa saúde com os cabelos brilhantes e cacheados e os colos claros e carnudos. Assim, adquirem lordose por tanto apertarem-se em espartilhos para realçarem o busto e os quadris, e ao mesmo tempo, diminuírem a cintura.

O vestuário também é forma de exibir-se e seduzir. Mediante tal artifício, as mulheres demonstram qual seu status social e todas suas virtudes. No início do século XIX, a moda era os vestidos com grandes saias, que possuíam anquinhas, caudas e armações, saias que chegavam a medir três metros de diâmetro, que precisavam trinta metros de tecido para serem confeccionadas, assim a mulher de alta classe matinha distância do seus admiradores e ainda mobilizava uma criada que a ajudava a se locomover e sentar. Havia tipos de golas e mangas e determinadas alturas da cintura para cada estação do ano.

Porém, há uma mudança drástica na maneira de se vestir no final desse século, em que a moda toma inspiração nas heroínas da literatura romântica e do ballet, sempre representadas com muita delicadeza e leveza. Na literatura, a mulher apresenta toda sua beleza no rosto, na sua palidez, no seu olhar e cabelos negros. Assim, ornamentos como brincos, colares, tiaras foram elaborados para deixar em evidência tais partes do corpo. No ballet, o que era valorizado pela técnica das sapatilhas de pontas, era a leveza e silhueta feminina, algo que levou o figurino feminino perder a toda a opulência de tecidos e rendas e despojar-se em tecidos leves e cortes fluidos, acompanhando o corpo da mulher.

Entretanto, por que as mulheres precisariam preocupar-se tanto, ter tantos cuidados com a sua própria beleza, buscar estar sempre enquadrado no conceito estético masculino, independente do sofrimento e gasto financeiro?

Porque a beleza, além de ser o maior trunfo na conquista de um matrimônio satisfatório, é principal capital de troca. A mulher precisaria estar ligada a um homem para estabelecer-se na vida, mesmo as que trabalhavam, considerando que através dos séculos algo sempre se manteve inalterado: que o mais seguro e confortável emprego 
feminino era o de esposa. Por isso, quanto maior sua beleza, maior seria seu caráter; quanto mais acentuados os atributos físicos femininos, melhores mães seriam, e sendo as melhores conseqüentemente atrairiam os melhores parceiros, que as dariam uma vida melhor.

No jogo da sedução, o homem teria o papel ativo enquanto que a mulher seria a seduzida, porém essa passividade feminina era somente pretensa, já que a mulher dedicava muito de sua vida elaborando ou melhorando seus atributos para atrair o parceiro certo. Ela colocava-se às vistas de seus pretendentes e os esperava fazer-lhe a corte. A mulher lutava contra a natureza e adaptava-se a qualquer desconforto para atingir o ideal estético daquele que acreditava estar conquistando; quando, na verdade, ele já havia sido conquistado pela imagem que se apresentava na sua frente.

Não havia espaço para o envelhecimento, pois as mulheres velhas remetiam sempre a infertilidade, a decrepitude, o desmazelo com a vida. As velhas retratam as vilãs na literatura ou são caricaturas de deboche. A imagem da mulher podia apenas trazer aos olhos masculinos prazer, gozo e mais nada.

"Corpos femininos que não proporcionassem prazer visual aos homens eram difíceis de imaginar. Mulheres idosas raramente aparecem na iconografia do século XIX, excepto como caricaturas ou estereótipos edulcorados.” (HIGONNET, A. 1991: volume 4-317.)

A beleza era a mediação tática para a mulher alcançar todos os seus objetivos, era a única forma que as mulheres possuíam de convencer os outros a ações que as beneficiassem. A beleza almejada e usada pelas mulheres não é aquela que remete somente à sexualidade ou ao erotismo, mas sim uma de eficácia social; já que é a beleza que prenderá os olhares, é o primeiro instrumento de fixação do outro, para que só assim possa haver uma troca posterior. Prender o olhar do outro sobre si é o primeiro passo, a condição sine qua non para as possibilidades de trocas sociais.

A beleza construída pela mulher por diversos artifícios não provoca no homem desconfiança, a feminilidade exaltada dá ao homem uma confortável segurança, pois reforça a idéia masculina em que as mulheres vivem pela função de agradá-los. Tal engodo permite a ação exata pretendida pelas mulheres que é ter uma intervenção social específica em que o elemento sexual nada mais é que um meio. Quando a mulher finalmente capta o olhar do homem pode enfim propor o seu próprio ponto de vista, a sua maneira de estar e pensar no mundo, ou seja, de ser socialmente ativa. 


\section{3 - A mulher e a maternidade.}

A procriação era o principal objetivo do casamento para o homem, pois era essa a forma que suas propriedades e bens eram mantidos, com a ajuda dos herdeiros; além de ser para ele uma garantia na velhice de ser sustentado e cuidado. Então, após tantos embates para alcançar o matrimônio, a mulher fica diante da maior tarefa, melhor colocando, talvez único papel da sua vida adulta de importância social, o de ser procriadora e mãe. A ela então cabia colocar no mundo àqueles que iriam garantir sua subsistência, quando o marido ou as forças lhe faltassem.

Durante muito tempo, historiadores e pensadores discutiram a idéia de que as mães na idade média não tinham um grande vínculo afetivo com seus filhos, devido à alta taxa de mortalidade infantil e pela infância ainda não ser considerada um período de formação importante na vida do indivíduo. Perpetuou-se o pensamento que o vínculo afetivo materno e a importância da infância surgiram apenas nos século XIX e meados do XX, durante os quais a infância foi reconhecida como uma importante fase de construção de caráter do ser humano, além da medicina ter avançado ao ponto de evitar muitas doenças, complicações e mortes, tanto para as mulheres quanto para as crianças.

Entretanto, com estudos de diários e cartas femininas anteriores a esses séculos vê-se que havia um laço afetivo forte da mulher pelo seu filho, quando relatavam as benzeduras e patuás que poderiam trazer proteção à criança; o pavor da morte súbita noturna, ocorrida durante o sono da criança, os ritos e simpatias para vencer todas as doenças que atacavam na infância e da grande dor no momento em que se perdia uma criança.

A mãe tinha total responsabilidade pela vida da criança, seu crescimento, sua saúde e educação, assim como tudo que pudesse ocorrer com a criança caso houvesse uma morte prematura, alguma deformidade de nascença ou defeito de caráter era culpa da progenitora. Tudo que acontecesse com a criança refletia na opinião que todos teriam sobre o caráter da mulher.

"Nos tribunais, qualquer mulher perdia todas as possibilidades de referência a um caráter se alguém revelasse que ela tinha deixado o filho por alimentar ou sujo, ou consentido que vagueasse ao abandono.” (HUFTON, O. 1991: volume 3- 58.)

Devido a essa visão cultural e social, que atravessou os séculos XVII e XVIII e XIX, as mulheres viram-se impelidas a manter de todas as maneiras a saúde e bem estar 
de seus filhos. Assim, surgiram as amas de leite: mulheres que amamentariam os filhos de outras mulheres. As crianças pudessem passar pela infância ilesas, pois tanto a medicina como a crendice popular dessas épocas viam o aleitamento durante os dois primeiros anos de vida como maior garantia da sobrevivência dos rebentos.

Para tanto, o leite deveria ser puro. Ou seja, a mulher deveria manter um estilo de vida que não danificasse seu leite e por conseqüência não transmitir nenhuma doença ao seu filho. Por isso, a importância das amas de leite, pois elas despenhariam os papéis tão importantes daquelas mães que estavam impossibilitadas de cumprir esta tarefa adequadamente, por trabalharem o dia todo em fábricas ou locais perigosos, nas cidades, consideradas insalubres às crianças; ou mesmo, por certos tabus, que consideravam as relações sexuais extremamente prejudiciais neste período.

Assim, independente do nível social da mãe, a criança era quase sempre entregue a outra mulher para ser amamentada. As mães não poderiam arcar com a culpa e julgamento impostos pela sociedade quando seus bebês adoeciam e morriam, como também não poderiam permitir perder algum dos privilégios desfrutados como esposa caso seus maridos arranjassem uma amante no período da lactação, quando a mulher encontrava-se impossibilitada de cumprir suas obrigações conjugais. Por isso, preferiam entregar seus bebês a outras mulheres para amamentá-los.

"As exigências divergentes feitas às mulheres por sua casa natal paterna, por um lado, e seus lares maritais posteriores, por outro, começavam logo que deixavam seus pais e continuavam pela vida afora. Essas demandas conflitantes podiam exacerbar muito a insegurança das mulheres, despertando muita angústia e ódio como conseqüência." (WARNER, M. 1999: 261)

Durante muitos séculos, a mulher viveu sob a tutela masculina, ou melhor, subjugada por seu semelhante. O espaço feminino era delimitado pelos homens, o qual ela deveria ocupar e dar-se por satisfeita pela proteção e amparo proporcionados por eles. Entretanto, ao longo dos tempos, as mulheres em meio às adversidades e descrédito buscaram seu próprio espaço.

Mediante as pequenas e discretas conquistas, como cortar bem curto os próprios cabelos, usar calças compridas, escolher seu próprio cônjuge e ter prazer no leito matrimonial; houve também, as maiores, mais sofridas e difíceis conquistas, como ter o direito de estudar, votar, ter uma profissão e trabalhar por um salário. As mulheres assim colocaram-se na sociedade e adquiriram seu próprio status. 
O momento exato histórico em que as mulheres conquistaram e firmaram-se social, cultural e economicamente não se pode precisar ou apontar, mas certamente pode-se afirmar que as mulheres percorreram uma grande trajetória que as proporcionou a igualdade perante aos homens na sociedade contemporânea. 


\title{
V) ARTE E CIÊNCIA: O ENCONTRO DA PSICANÁLISE COM A LITERATURA.
}

\author{
"O estudo dos contos de fadas é essencial, para \\ nós, pois eles delineiam a base humana essencial." \\ Marie-Louise Von Franz.
}

Há narrativas que perduram por tantos séculos, em diferentes culturas e continentes, que nos fazem questionar o porquê dessa longevidade. Haveria de ser por falta de inspiração que as temáticas narrativas repetem-se, mudando apenas alguns detalhes; ou então, haveria de ser ter um motivo mais complexo para que certos assuntos sejam abordados sempre sem esgotamento?

O motivo dessa longevidade, na verdade, deve-se à significação dessas narrativas, pois elas representam acontecimentos, comportamentos e sentimentos humanos que são entendidos e aceitos por todos os grupos humanos. Tais narrativas foram alimentadas por elementos psíquicos presentes em nossos inconscientes que afloraram em representações artísticas e agora fazem parte do imaginário popular na forma de lendas, mitos, fábulas e contos de fadas.

"Para mim os contos de fada são como o mar, e as sagas e os mitos são como ondas desse mar; um conto surge como um mito, e depois afunda novamente para ser um conto de fada. Aqui novamente chegamos à mesma conclusão: os contos de fada espelham a estrutura mais simples, mas também a mais básica - o esqueleto - da psique." (VON FRANZ, M. L. 2005: 33)

A obra literária não é um retrato, uma foto da realidade, mas sim uma visão estilizada, simbólica, psíquica e poética das bases humanas. Nos acontecimentos ficcionais ficam claras e expostas as ambigüidades da vida, por meio do discurso da personagem e do narrador, ou mesmo, do autor, mostrando as diferenças que podem existir nos indivíduos na maneira de agir, sentir e absorver os impactos da vida.

A ficção é o único lugar em que o ser humano pode tornar-se transparente a si mesmo, pois o espaço imaginário da narrativa une personagens repletas de emoções e intenções, sem referências diretas ao leitor ou ouvinte. Tais personagens são totalmente projetadas em nossas mentes mediante as descrições de suas ações, 
dando assim espaço para enxergá-las conforme nossa interpretação, ou melhor, conforme nossas vivências.

A literatura funcionaria, então, como um elemento conservatório dos mitos, crenças e valores que sobreviveram através dos tempos pelas formas orais, pictográficas e escritas. Constatamos assim, que muitas formas de agir, pensar ou sentir sobre determinados valores ou conceitos da vida, podem chegar até nós envoltos em literatura e que ela nos proporciona uma fecunda fonte de análise humana. Assim, podemos ter vários comportamentos humanos exemplificados nas narrativas míticas, em fábulas, contos de fadas e romances.

Entretanto, o foco de estudo e análise dessa dissertação é o conto popular, em especial o de fadas, porém, isso não significa que pequenas explanações de outras formas narrativas semelhantes, não auxiliem na compreensão e importância dessa representação escrita das virtudes, vícios e desejos da índole humana.

"Por existirem inúmeras coisas fora do alcance da compreensão humana é que freqüentemente utilizamos termos simbólicos como representação de conceitos que não podemos definir ou compreender integralmente." (JUNG, C. G. 2008: 19)

Nas sociedades primitivas, o mito era uma forma muito importante e eficaz de transmitir de conhecimento e cultura para as próximas gerações, como também, explicar ou dar sentido aos fatos que fugiam do poder humano. $\mathrm{O}$ conto de fadas além de ser uma narrativa muito antiga, também busca dar sentido e explicações para fatos da vida do indivíduo. Assim, em grau de importância o mito está para a sociedade, tanto quanto o conto de fadas está para o indivíduo.

O conto apresenta grande proximidade com o mito, pois ambos são expressos por um locutor/narrador anônimo, de traços indefinidos. São narrativas de caráter retrospectivo que bebem na tradição coletiva para tomarem suas formas, fazem parte da memória humana e ainda possuem uma grande capacidade de mutação sem que percam suas essências, que, na verdade, as caracterizam.

Pode-se refletir sobre algumas questões levantadas no Dicionário de Mitos Literários de Pierre Brunel, em um texto muito interessante de Max Bilen intitulado “Comportamento mítico-poético”, no qual o autor enumera as várias diferenças entre o mito e a narrativa literária dizendo:

"A narrativa romanesca é mais ou menos fictícia, a narrativa mítica impõe-se como verdadeira; o poema é intraduzível, enquanto a narrativa mítica 
pode ser traduzida em todas as línguas; o texto literário é estruturado em suas partes, enquanto a narrativa mítica é um conjunto de símbolos, podendo até reduzir-se a uma estrutura permanente; (...) Enfim, comparada à narrativa literária, a narrativa mítica tem na maioria das vezes um caráter iniciático e transcendental.”(BILEN, M. 1988)

O conto de fadas está na fronteira desses dois gêneros, pois sua temática narrativa sempre está envolta aos problemas da índole e identidade humanas, mas disfarçados sob a fantasia, ou seja, o conto de fadas apresenta um dilema existencial de forma breve e categórica no meio de seres e acontecimentos mágicos.

Essa fronteira é muito tênue, se analisarmos que muitos mitos sobreviveram até o presente momento, e se considerarmos ainda que a palavra mito originou-se do grego muthos, significando: palavra, narrativa transmitida. Seria, então, impossível afirmar que o mito não esteja de alguma forma estruturada na literatura, já que este precisa ser transmitido, e assim o é, evidentemente se fará presente em várias expressões literárias.

Os heróis míticos possuem dimensões sobre-humanas, são como deuses, pois eles criam o mundo e controlam os elementos da natureza, entre outras coisas; enquanto que as personagens dos contos de fadas são figuras fáceis de nos identificarmos, apesar de possuírem alguns poderes ou viverem determinadas situações sobrenaturais, elas vivem os dilemas, angústias e alegrias do seres humanos ordinários.

"Através dos séculos (quando não dos milênios) durante os quais os contos de fadas, sendo recontados, foram-se tornando cada vez mais refinados, e passaram a transmitir ao mesmo tempo significados manifestos e encobertos - passaram a falar simultaneamente a todos os níveis da personalidade humana, comunicando de uma maneira que atinge a mente ingênua da criança tanto quanto a do adulto sofisticado." (BETTELHEIM, B. 2003: 14)

Ainda no dicionário de mitos literários há outra passagem que cita a crença que os irmãos Grimm possuíam em relação aos mitos e contos, sendo que este primeiro seria a base da poesia mais antiga, por sua forma de interpretar "as coisas supersensíveis”. Para estes filólogos alemães os contos teriam conservado fragmentos e restos de mitos sob uma forma elíptica, mas muito alusiva, e que por fim dessacralizavam os mitos.

Já para Propp, há uma pequena distinção entre mito e conto. O mito é definido por ele como uma narrativa portadora de verdades religiosas aceitas e reconhecidas por todos em uma sociedade, enquanto que o conto surge a partir de uma falha nesta estrutura, quando os ritos e crenças que inspiraram o mito desaparecem, os conceitos, 
conteúdos e valores transmitidos pela narrativa mítica recebem uma nova roupagem e geram os contos.

Os mitos, fábulas e contos de fadas, então, têm muito em comum, pois eles podem expressar um conflito interno de forma simbólica e sugerir como resolvê-lo; entretanto, o que os diferem é a forma na qual apresentam os conflitos internos aos leitores e ouvintes. O conto de fadas, ao contrário das outras duas narrativas citadas, apresenta-se de uma forma simples, ele não faz solicitações ao seu receptor, nunca o leva a sentir inferior e há sempre uma promessa de estabilidade em seu final.

"O conto de fadas nunca nos confronta diretamente, ou diz-nos francamente como devemos escolher. Em vez disso, ajuda as crianças a desenvolverem o desejo de uma consciência mais elevada, apelando à nossa imaginação e ao resultado atraente dos acontecidos, que nos seduz." (BETTELHEIM, B. 2003: 43)

O conto de fadas é uma narrativa otimista, que retrata os conflitos humanos, mas sempre trazendo resoluções positivas ao final, enquanto os mitos e fábulas tratam sempre de aspectos mais negativos da índole humana e ao final delas há imposição de um castigo ou punição pelas ações das personagens, e não a aprendizagem e superação de seus defeitos e conflitos, como no conto de fadas.

As crianças, por diversas formas de conteúdos simbólicos presentes nos contos de fada, acabam sendo o maior público dessas narrativas, mas o mais importante e talvez o que mais as atraiam é a maneira pela qual o conto de fadas proporciona um afastamento da criança com a realidade e seu inconsciente. Tal fator colabora com o crescimento psicológico da criança, pois para ela é muito importante enxergar seus dilemas internos como algo que independem delas para o seu aparecimento, e só assim podem encará-los e dominá-los sem medo.

Há diversos fatores para a identificação dos leitores ou ouvintes com os contos de fadas identifiquem-se, pois além de toda essa sedução causada pelas soluções felizes de nossos conflitos, há ainda a forma de realização individual nas personagens. Elas muitas vezes não têm nomes próprios, apenas apelidos recebidos por alguma característica física, vivem em lugares indefinidos ou desconhecidos. Ou seja, todos esses fatores colaboram para uma ligação significativa do leitor ou ouvinte com o conto de fada, de fazer uma projeção de sua vida e envolver-se significantemente com a narrativa. 
"Para que o conto de fadas tenha uma externalização benéfica, a criança deve permanecer desinformada das pressões inconsciente às quais está respondendo quando torna suas as soluções das estórias de fadas." (BETTELHEIM, B. 2003: 74)

A mente humana produz idéias, conceitos ou sentimentos que nunca estão presentes o tempo todo de forma consciente na vida do indivíduo. Esses elementos psíquicos que formam a identidade e índole humana são muitos e diversos para serem conhecidos e controlados sempre pelos indivíduos. Assim, esses elementos vêm à tona no consciente em determinados momentos específicos e relevantes, para depois recolherem-se novamente ao inconsciente, quando não forem mais necessários.

Desse modo, entende-se que para maior aprofundamento e interpretação adequada dessa área artística, faz-se necessário não apenas o estudo dos gêneros ou escolas literárias que a influenciaram, como também a outras áreas do campo científico social, cultural e psicanalítico. Na literatura, teremos os mitos e os contos retratando de problemas humanos universais, enquanto na psicanálise teremos os arquétipos.

"Outra forma bem conhecida de expressão dos arquétipos é encontrada no mito e no conto de fada. Aqui também, no entanto, se trata de formas cunhadas de um modo específico e transmitidas através de longos períodos de tempo." (JUNG. C. G. 2006: 17)

Visamos, então, entender como foram construídas essas narrativas, que tiveram sua origem há vários séculos passados, transmitidas na forma oral e sendo, posteriormente, compiladas e modificadas por diversos estudiosos e autores. Assim, aqui analisaremos os fatores psicológicos ligados às essas narrativas populares de autores anônimos.

Para melhor entendermos como serão feitas as análises dos contos de fadas do corpus desse trabalho, primeiro apresentamos o conceito de arquétipo elaborado pelo psicanalista Carl Gustav Jung:

“O arquétipo - e nunca deveríamos esquecermo-nos disso - é um órgão anímico presente em cada um. (...) Ele representa ou personifica certos acontecimentos instintivos da psique primitiva obscura, das verdadeiras, mas invisíveis raízes da consciência. O elementar significado da conexão com essas raízes é-nos mostrado pela preocupação da mente primitiva com relação a certos fatos 'mágicos', os quais nada mais são do que aquilo que designamos por arquétipo.” (JUNG, C. G. 2006: 161)

O arquétipo, então, nada mais é do que construções significativas sobre fatos ou acontecimentos não palpáveis; em outras palavras, o arquétipo é a estória que se cria 
para se explicar sentimentos, mudanças psíquicas e sociais ocorridas nos indivíduos e sociedades. Jung ainda relata que "um conteúdo arquetípico sempre se expressa em primeiro lugar metaforicamente." Ou seja, o arquétipo é a materialização em imagens de valores e sentimentos humanos.

Quando um indivíduo tem uma experiência arquetípica impactante, ou seja, a conscientização e modificação de algum conteúdo inconsciente, que traga entendimentos e mudanças na vida dele; há uma necessidade de transmiti-la ao invés de guardá-la.

Encontramos essa primeira expressão metafórica, muitas vezes, em contos de fadas, já que eles são capazes de conectar seus leitores não apenas a elementos maravilhosos, como também a diversos sentimentos e valores, os quais a humanidade sempre se reconhece, independente da época e cultura.

"(...) o inconsciente está na mesma posição de alguém que teve uma visão ou experiência original e quer compartilhá-la. Pelo fato de ser um evento que nunca foi formulado conceitualmente, ele não sabe como se expressar. Quando uma pessoa está nessa situação, faz diversas tentativas para compreender sua experiência e tenta evocar, por apelo intuitivo e analogia a materiais familiares, alguma resposta em seus ouvintes; e não se cansa nunca de expor sua visão, até sentir que o conteúdo desta faz algum sentido para eles." (VON FRANZ, M. L. 2005: 10)

Essa expressão metafórica na forma de narrativa, oral ou escrita, tem início nos conteúdos psíquicos e está presente no inconsciente de cada pessoa. Os sentimentos e transformações ocorridos no íntimo de cada indivíduo, mesmo parecendo serem sensações únicas e exclusivas, na verdade são compartilhadas por todos, no sentido em que em determinados momentos de nossas vidas, experimentamos as mesmas experiências emocionais. Os conteúdos psíquicos que alimentam as narrativas antigas encontram sua inspiração e renovação no imaginário das pessoas, das culturas ou sociedades.

Porém, como que cada estória que ouvimos a primeira vez quando crianças ou mesmo adultos, nos parecem ser às vezes tão familiares ou escritas especialmente para nós? Como algumas estórias parecem terem sido roubadas de nós? O espanto de ler ou ouvir aquilo que você acreditava ser o único a crer, saber ou sentir; como explicar tudo isso?

Um conto não é apenas uma estória, quando uma narrativa entra no cânone literário, ou apresenta-se como um mito ou lenda de determinado povo ou local, essa 
narrativa na verdade foi subjugada por uma sociedade. Há uma estória com um determinado tema, que conforme época e cultura, ganha uma roupagem; há uma certa mistura de medos, alegrias e aventuras que servem como meio de transmissão da herança simbólica de cada cultura e sociedade.

Embora o mundo tenha mudado demasiadamente, certos assuntos e temas permanecem atuais, ou melhor, ainda considerados inexplicáveis ou misteriosos, e acabam reverberando pelo tempo. Isso acontece com o amor, as relações familiares e a construção das identidades, tanto masculina quanto feminina. As narrativas antigas, como os contos de fadas e os mitos, na verdade confrontam seu leitor ou ouvinte com toda a precariedade da existência humana; com os conteúdos mais bem guardados no inconsciente.

"O conto de fadas, por outro lado, em grande parte resulta do conteúdo comum consciente e inconsciente tendo sido moldado pela mente consciente, não de uma pessoa em especial, mas do consenso de várias a respeito do que consideram problemas humanos universais, e o que aceitam como soluções desejáveis." (BETTELHEIM, B. 2003: 46)

Todos os elementos psíquicos, que nos fazem humanos e constituem nossa índole, não são controlados e muito menos reconhecidos pelo nosso raciocínio lógico. A nossa mente produz idéias, conceitos ou sentimentos que nunca estão o tempo todo presentes em nossas vidas no nível consciente; eles vêm à tona em determinados momentos e depois se recolhem novamente em nosso inconsciente.

Tudo o que é reprimido, ou seja, não é explicado ou entendido pelo indivíduo, encontra-se no inconsciente. Entretanto, nem tudo que é inconsciente, será necessariamente reprimido. Em outras palavras: temos muitas coisas estão submergidas no inconsciente e, às vezes, emergem e são colocas no consciente sob diversas formas concretas, através ações, atitudes e expressões artísticas, enquanto há outras que ficarão sempre imersas no inconsciente.

Os problemas e dilemas do crescimento humano estão refletidos nos contos de fadas, são retratados simbolicamente, e eles e ajudam a seus leitores não a apenas sentirem conforto e segurança durante esse período da vida, mas também de entenderem e exercerem algum domínio das situações e sentimentos ainda não reconhecidos pelo raciocínio lógico. 
"O homem realmente necessita de idéias gerais e convicções que lhe dêem um sentido à vida e lhe permitam encontrar seu próprio lugar no mundo. Pode suportar as mais incríveis provações se estiver convencido de que elas têm sentido. Mas sente-se aniquilado se, além de seus infortúnios, ainda tiver de admitir que está envolvido numa 'história contada por um idiota'." (JUNG, C. G. 2008: 111)

Assim, essas narrativas mágicas encontradas nos contos de fadas ajudam as crianças a lidarem com os conteúdos inconscientes da identidade e personalidade e adequarem suas fantasias à realidade; os contos de fadas dão a possibilidade de estruturação do inconsciente e dos devaneios das crianças, dando-lhes um melhor entendimento e direção para a vida; permitindo-lhes encontrar seus lugares no mundo.

Entretanto, devemos citar que para Freud o inconsciente é de natureza exclusivamente pessoal, e cada indivíduo possui o seu; porém para Jung existe além desse inconsciente individual também um inconsciente coletivo, no qual os elementos psíquicos são compartilhados por todos os seres humanos, independentes de culturas ou épocas, fazendo assim com que todos tenham algo em comum:

"Eu optei pelo termo "coletivo" pelo fato de o inconsciente não ser de natureza individual, mas universal; isto é, contrariamente à psique pessoal ele possui conteúdos e modos de comportamento, os quais são 'cum grano salis' os mesmos em toda parte e em todos os indivíduos. Em outras palavras, são idênticos em todos os seres humanos, constituindo portanto um substrato psíquico comum de natureza psíquica suprapessoal que existe em cada indivíduo.” (JUNG. C. G. 2006: 15)

Jung reforça a idéia que este inconsciente coletivo pode ser manifestado, vir à tona, através de "fórmulas conscientes”, ou seja, estórias transmitidas oralmente por povos ou rituais esotéricos, nos quais os elementos psíquicos guardados no inconsciente coletivo são expostos e vivenciados de uma maneira mais consciente, assim podemos considerar estes como os canais nos quais os conteúdos do inconsciente coletivo serão transmitidos para o consciente.

Os mitos e os contos de fadas falam de maneira simbólica, representando conteúdos inconscientes. O apelo nessas narrativas é tanto à nossa mente consciente, quanto à inconsciente; por isso são tão populares e mergulhar nessas fórmulas ou estórias e vivenciá-las, no momento da leitura, podem parecer uma negação da realidade, mas na verdade, a fantasia dessas narrativas possibilita uma maneira de refletir sobre os possíveis destinos que podemos tomar conforme nossas decisões e atos.

A onipresença do bem e do mal nos contos de fadas faz o elo da ficção com a realidade, com a vida; pois esses elementos estão presentes o tempo todo nas vidas das pessoas, e todos indivíduos tem propensões tanto para um quanto para o outro. O bem e 
o mal recebem um corpo através das personagens e têm suas conseqüências conforme suas atitudes nas narrativas dos contos de fadas.

Essa forma simplificada de retratar a sociedade e as questões pessoais é muito reveladora, pois em uma estória maniqueísta em que o mal é castigado e o bem, depois de testado e comprovado seu valor, é recompensado, ajuda a entender os pontos centrais da índole e convivência humana. Não há disfarces ou rodeios sobre sentimentos e valores já vivenciados por todos, ao menos uma vez, tudo é mostrado na sua forma mais crua e simples, indicando exatamente as maiores aflições humanas.

"Então a criança tem uma base para compreender que há grandes diferenças entre as pessoas e que, por conseguinte, uma pessoa tem que fazer opções sobre quem quer ser. Esta decisão básica sobre a qual todo o desenvolvimento ulterior da personalidade se construirá, é facilitada pelas polarizações dos contos de fadas." (BETTELHEIM, B. 2003: 18)

A fim de dominar os problemas que afetam a nossa base humana, os enigmas psicológicos, o indivíduo precisa entender o que lhe está afetando, qual a origem do distúrbio que lhe perturba. Para tanto, nada melhor que o conto de fadas, pois ele indica ao leitor ou ouvinte o caminho a tomar do inconsciente até chegar a entendimento mais elaborado, ou ao menos uma familiarização maior com sua identidade e personalidade.

Dessa forma, o conto de fadas é encarado no campo da psicanálise como uma maneira de reformulação dos problemas psíquicos, de solucionar ou esclarecer conteúdos difíceis da personalidade humana; porém no campo literário eles são uma riquíssima forma de arte, pois tocam e envolvem a maioria das pessoas que os lêem.

"(...) a criança adéqua o conteúdo inconsciente às fantasias conscientes, o que a capacita a lidar com este conteúdo. É aqui que os contos de fadas têm um valor inigualável, conquanto oferecem novas dimensões à imaginação da criança que ela não poderia descobrir verdadeiramente por si só. Ainda mais importante: a forma e a estrutura dos contos de fadas sugerem imagens à criança com as quais ela pode estruturar seus devaneios e com eles dar melhor direção à sua vida." (BETTELHEIM, B. 2003: 16)

A psicanálise, como toda ciência, existe para ajudar o homem, ela não surgiu apenas para entender o funcionamento da mente humana, mas para também auxiliar no seu desenvolvimento e manutenção da sanidade. Uma das melhores formas de se entender a mente humana, como temos visto até aqui, é através da arte, e em nosso caso, a do conto de fadas. 
O estudo psicanalítico dos contos de fadas é importante, porque além de deixarem transparecer aspectos da mente e psique humana, eles também auxiliam no desenvolvimento da identidade e personalidade; assim como faz o acompanhamento psicológico. Os contos também ajudam o indivíduo a aceitar a natureza problemática da vida sem ser derrotado por ela, ou levado ao escapismo.

Esse gênero literário está repleto de cenários iniciáticos, ou seja, há representações diversas de acontecimentos únicos na vida de cada um, como o início da adolescência, o da construção da personalidade, o da primeira paixão, e tantos outros inícios, que sempre despertaram medo, angústia e insegurança, justamente por serem a primeira vez em alguma coisa nova. Porém, os contos tratam dessa temática e transmitem suas mensagens de forma imaginativa, com um refinamento e qualidade que através os tempos.

Por isso, é tão importante entender o que há por trás das figuras e situações usadas nos contos de fadas. O que elas representam, onde elas podem levar o leitor ou ouvinte e por que algumas são sempre recorrentes? As figuras e imagens apresentadas nos contos de fadas representam as diversas emoções e lados da personalidade e índole humana ao longo de sua existência.

Muitos leitores acreditam que os contos de fadas são feitos para um público especificamente infantil, assim as personagens deveriam seguir as expectativas ou a imaginação dos pequenos leitores, ou seja, sejam animais falantes, seres mágicos, crianças ou jovens heróis capazes de escapar de quaisquer peripécias, entretanto isso não corresponde ao seu verdadeiro papel; os contos de fadas não são leituras infantis e suas narrativas não remetem à apenas problemáticas do mundo infantil, mas sim, guardam aspectos humanos verdadeiros e universais.

"A voz do inconsciente coletivo, que é como um tesouro de memórias guardadas sobre como é viver com os outros, deve ser ouvida, sobretudo quando se trata de grandes acontecimentos em nossa vida, como um casamento, como o despertar da vida sexual, ou o confronto com a morte." (BONAVENTURE, J. 2000: 197)

Assim, todo conteúdo simbólico apresentado nos contos de fadas tem em seu propósito não apenas o lúdico, mas também, o de levar seu leitor ou ouvinte à reflexão. Veremos a seguir algumas representações e simbologias importantes nos contos de fadas, aquelas que são de interesse da pesquisa feita, dentro do seu recorte e enfoque do 
corpus de análise, sendo esse voltado à figura feminina. As personagens, na verdade, são caricaturas de vários comportamentos encontrados nas mulheres. Pois:

"Um arquétipo é um assunto que é sempre o mesmo, mas que pode se manifestar através de milhares de símbolos diferentes, de sonhos, fantasias, vivências, e parece sempre novo na hora que o vivemos. E a mulher é um arquétipo. Não a mulher concreta, mas a Mulher." (BONAVENTURE, J. 2000: 13)

Explorarei a seguir, então, os dois extremos do arquétipo feminino: a figura infantil e a madura, pois apesar de estarem em lados opostos, essas figuras complementam-se, ou melhor, a primeira evolui à segunda. A mulher pode ser apresentada de diversas formas: mimadas, egoístas, fofoqueiras, espertas, más, bondosas, feiticeiras, inocentes, etc. Porém, todas elas serão muito jovens ou mulheres maduras.

"Na vida real, ela pode ter todos os aspectos femininos dentro dela, tanto da fada como da bruxa, da menininha abandonada ou da madrasta mais malvada, além das características masculinas. Nos contos, ou as personagens femininas são boas ou são más, tímidas ou orgulhosas, bonitas ou feias. Não parece haver meio termo nem combinação dos opostos. O que eles mostram muito bem é a dinâmica que existe entre estes diversos aspectos de nosso ser. Porque um aspecto sempre chama seu oposto." (BONAVENTURE, J. 2000: 19)

O cerne dessa dissertação está em analisar as figuras femininas nos contos de fadas diante de seus dilemas existenciais, ou seja, aquelas que se deparam com as dificuldades de formar-se e ser mulher, as que ao longo das narrativas crescem e consolidam sua identidade e personalidade, deixando suas atitudes infantis para trás.

Os contos apresentados no corpus de análise buscam justamente as heroínas que sofreram diversos revezes, mas superaram todas as dificuldades e alcançaram a felicidade. Assim, a figura da criança, ou melhor, de uma menina, será na maioria das vezes a protagonista das narrativas; entretanto, essas personagens não foram pensadas ou colocadas nas narrativas exclusivamente para atrair leitores mais jovens, mas por ser rica em representações e simbolismos.

"Um aspecto fundamental do motivo da criança é o seu caráter de futuro. A criança é o futuro em potencial. Por isso a ocorrência do motivo da criança na psicologia do indivíduo significa em regra geral uma antecipação de desenvolvimentos futuros, mesmo que pareça tratar-se à primeira vista de uma configuração retrospectiva." (JUNG, C. G. 2006: 165) 
A figura da criança é importante para que haja a menção de esperança e renovação, para entender que há ciclos na vida, um caminho em que o indivíduo encontra-se no começo, em um estágio menos apto a lidar com certos problemas, e ao término dele ele já superou suas inaptidões e está mais maduro, transformado. A imagem da criança remete ao ser do começo, do pré-conhecimento, como também ao ser do final, o ser revitalizado, renascido no conhecimento.

Essa imagem remete ao amadurecimento, alguém em rumo à autonomia, pois a criança só pode desenvolver e crescer, desligando-se de sua vivência anterior, superando seu passado. A criança é o sinal do vir a ser, ou seja, da auto-realização, da libertação de pensamentos e atitudes infantis e precárias para a conquista de plenitude e controle de sua própria vida.

A criança é interpretada leigamente como um ser simples e espontâneo, desprendido de maldade e pensamentos dissimulados, então, ela também pode representar uma vitória sobre a complexidade de diversos problemas humanos, vir a ser a figura que aplaque a ansiedade de determinadas conturbações.

"Os contos mostram como essas figuras femininas vão deparando com as dificuldades da vida e como vão crescendo, dedicando-se, por exemplo, à tarefa de sair de sua situação de infantilidade." (BONAVENTURE, J. 2000: 14)

A simbologia é muito forte em relação ao processo de crescimento interno, do amadurecimento psíquico. A criança indica que haverá descoberta e transformações, ela é uma síntese de elementos conscientes e inconscientes da personalidade, que brevemente irão se unir, reformularem e atingir um novo estágio na mente. É o processo de individuação de cada pessoa, a sua identidade criando sua própria forma e se tornando única.

"'Criança" significa algo que se desenvolve à autonomia. Ela não pode tornarse sem desligar-se da origem: o abandono é pois uma condição necessária, não apenas um fenômeno secundário." (JUNG, C. G. 2006: 169)

Uma última observação importante sobre a imagem simbólica da criança é: quando ela aparece abandonada, significa a incompreensão do outros em relação a si. O sentimento de ser injustiçado pelo mundo é comum aos indivíduos nos momentos de transições pessoais, por isso os contos trazem crianças ou jovens sendo tratados como pessoas pretensiosas ou incapazes de concretizarem ou realizarem de maneira bem feita 
qualquer tarefa na fase de crescimento; refletindo assim, os sentimentos de qualquer ser que está passando por crescimento interno.

As narrativas populares mostram as personagens sendo expulsas dos lares ou abandonadas por um ente querido antes do desenvolvimento de suas identidades, pois o desenvolvimento humano envolve uma grande parcela de esforço individual e próprio, dando assim, muitas vezes, a sensação de abandono e isolamento ao indivíduo que está passando por algum crescimento psíquico.

Passado esse momento de maior desenvolvimento interno, há ainda outras transformações e desenvolvimento psíquico, mas os quais estarão refletidos em diversas outras imagens, afinal sendo a fase a adulta àquela de lapidação da personalidade do indivíduo, as sensações e experiências serão outras.

A imagem, que agora interessa no recorte de nossa análise, é aquela que reflete a mulher mais velha, da adulta em frente aos seus novos desafios e responsabilidades. $\mathrm{Na}$ verdade, essa mulher pode ser apresentada nos contos de fadas sob as mais variadas formas, desde a forma boa de mãe até a forma cruel e má de bruxa, porém independente da imagem ou figura apresentada ela remeterá a mulher na transição com suas maiores transformações na fase adulta: o casamento e a maternidade.

O casamento é a finalização de diversas narrativas, as protagonistas após passarem por diversos testes, tarefas ou dificuldades são presenteadas ao final com uma vida repleta de felicidades no matrimônio. Isso porque, o casamento é um símbolo de unificação, ou seja, de amadurecimento. O casamento aponta para o indivíduo que já possui um bom autoconhecimento e é capaz assim de se relacionar com outro ser, de igual para igual.

"Na análise jungiana, o casamento simboliza, no curso do processo de individualização ou de integração da personalidade, a conciliação do inconsciente, princípio feminino, com o espírito, princípio masculino." (CHEVALIER, J. 2008: 197)

Assim, pela visão psicanalítica o casamento seria a representação do processo natural e saudável do desenvolvimento psíquico de um adulto, e para os leitores ou ouvintes dos contos seria a transformação dos sonhos almejados pelas protagonistas em realidade.

Porém, ao nosso estudo convém ater-se à simbologia arquetípica da mãe. A sua presença na narrativa remete a dois aspectos fundamentais: o construtivo e o destrutivo. A figura materna representa a primeira experiência do indivíduo com algum conteúdo 
do inconsciente, e a partir da reformulação que se fará desse contato, o indivíduo passará por uma mudança, que pode ser tanto positiva quanto negativa. Assim, três movimentos da vida são projetados nessa figura: a criação, a manutenção e a destruição. Mas, há uma ressalva a ser feita, o arquétipo materno tem uma significação diferente para os homens e as mulheres, afinal a maternidade é vivenciada apenas um gênero da espécie: a mulher.

"Para a mulher a mãe é o tipo de sua vida sexual consciente. Para o homem porém a mãe é o tipo de estranho, ainda a ser vivenciado e preenchido pelo mundo imagístico do inconsciente latente." (JUNG. C. G. 2006: 112)

Enquanto a imagem arquetípica da mãe para as mulheres está focada em um aspecto, o sexual, para os homens ela é a representação de todo desconhecido a ser aprendido e compreendido por eles. A convergência que há na significação é o conhecimento ou a consciência de conteúdos da base humana.

A mãe é a figura que ajuda a contraposição de algum conteúdo inconsciente para abrir caminho individuação, para a construção da identidade. Ela apresenta a possibilidade do indivíduo diferenciar-se de conceitos ou conteúdos pré-existentes e assumir seus próprios valores, entender e apropriar-se dos conteúdos psíquicos que lhes são válidos.

Como a figura materna pode simbolizar tanto aspectos positivos quanto os negativos, sua representação pode sofrer várias alterações ao longo de uma narrativa ou pode se apresentar de diversas maneiras. O arquétipo da mãe pode estar na avó, fada madrinha, madrasta, dragão, bruxa.

"Tudo o que o pensamento popular projeta nas figuras femininas, tudo o que ele espera de comportamento das mulheres vai sendo descrito nesses contos. E o que há de mais incrível é que as expectativas sobre o feminino na China, na Rússia, na Noruega, no Brasil ou no Marrocos são muito semelhantes." (BONAVENTURE, J. 2000: 17)

Em outras palavras, os arquétipos surgem em diversas formas nas personagens dos contos de fadas para demonstrarem certos comportamentos humanos, como também, para demonstrarem qual a melhor forma de se lidar com o desenvolvimento interno. 


\section{VI) AS IMAGENS DA MULHER}

Os capítulos anteriores apresentaram os aspectos teóricos relevantes para o estudo do corpus selecionado para essa dissertação, como também, apontam a linha de pensamento seguida para a interpretação e análises que seguirão nesse capítulo.

As análises dos textos literários a seguir foram baseadas, ou melhor, focadas em uma linha psicanalítica, a qual pode apontar com maior clareza como a literatura pode ser um importante espaço catártico para a humanidade.

Dessa forma, as narrativas escolhidas: Branca de Neve, A mulher e a filha bonita, Rapunzel e A moça tecelã não foram feitas aleatoriamente, mas buscam na verdade mostrar como essa forma artística pode ser tão marcante e recorrente no universo feminino.

\section{1) Branca de Neve compilada pelos irmãos Grimm.}

O conto dos irmãos Grimm trata de uma princesinha nascida com os cabelos muito negros, pele alva como a neve, porém tão corada como o sangue conforme desejado pela sua mãe. Entretanto, logo após o parto, esta mãe morre, e em um curto período, o Rei casa-se novamente com uma mulher muito bela e orgulhosa. Esta não admitia a possibilidade de haver outra mulher mais bela do que ela. Assim, possuía um espelho mágico ao qual perguntava todos os dias: quem era a mulher mais bela do reino? A nova Rainha era sempre a escolhida.

Branca de Neve torna-se uma bela jovem que suplanta o lugar de beleza ocupado pela segunda, a rainha, e portanto, agora o espelho mágico sempre responde que a mais bela mulher é Branca de Neve. Com ódio a rainha manda que um caçador de sua confiança leve Branca de Neve para a floresta, mate-a e traga seus pulmões e fígado para que ela os coma. Entretanto o caçador tem piedade da bela jovem e a deixa viva na floresta, enganando a Rainha, trazendo-lhe os órgãos de um animal morto por ele.

Nesta floresta, Branca de Neve encontra abrigo em uma pequena casa e a proteção de seus pequenos moradores: sete mineradores anões. Lá a jovem é responsável pelos afazeres domésticos enquanto que os anões trabalham durante o dia todo. Estes sempre a alertam sobre o perigo de sua madrasta lhe encontrar e, por isso, 
ela nunca deve deixar ninguém entrar na casa ou mesmo aceitar qualquer coisa de pessoas estranhas.

Como havia sido previsto pelos anões, a madrasta encontra sua jovem enteada e bela rival, mas disfarçada de uma velha vendedora de maçãs, oferece uma maçã a Branca de Neve, que ao mordê-la cai imediatamente no chão. Quando os anões a encontram, colocam-na em um esquife de vidro para que ainda pudessem admirá-la.

Um dia, um nobre príncipe atravessando a floresta viu Branca de Neve deitada no esquife e implorou aos anões para que o deixassem levá-la consigo. Os anões permitiram e quando os servos do príncipe começaram a carregar o pesado esquife de Branca de Neve, tropeçaram e o derrubaram. Neste momento, pula de dentro da garganta da bela princesa o pedaço da maçã que havia mordido e, logo em seguida, a jovem abre os olhos e senta-se muito viva e bem disposta. O conto termina com o casamento de Branca de Neve com o nobre príncipe e sua madrasta morrendo de tanto dançar em sapatos enfeitiçados feitos de ferro bem quentes.

O conto já traz logo em seu início a morte da mãe, figura que geralmente não nos remete a sentimentos hostis ou de desalento, ao contrário, a mãe nos remete a segurança, amor e carinho. Entra, porém em cena, no lugar da mãe amável, a madrasta bela e imponente. Esta substituição é imprescindível no desenrolar da trama, já que o conto tratará de relacionamento no qual a inveja e o ciúme femininos são as protagonistas.

A mulher que dá a luz à Branca de Neve morre no parto. Essa mulher foi uma filha, a esposa de alguém e agora a mãe de um novo ser humano. Antes de alcançar o papel de mãe, a mulher já desempenhou outros papéis familiares mas agora ela estará em frente de um novo papel, de novas perspectivas, expectativas, e o mais importantes, novas escolhas.

A maternidade chega com alguns dilemas em que a nova mãe deverá descobrir sozinha as respostas. A mulher deverá abdicar de seu marido para dedicar-se exclusivamente ao seu filho? Ela deverá abandonar todas suas vaidades, pois como mãe elas são desnecessárias? Ela deve abandonar por completo os outros papéis familiares e dedicar-se somente a esse, pois só assim seria uma boa mãe?

As respostas a essas perguntas não são dadas ou ensinadas por ninguém ou podem ser as mesmas para todas novas mães, porém certamente o momento de angústia para essas mulheres é o muito similar. Este momento é uma nova encruzilhada no 
caminho feminino, em que a mulher deverá refletir e decidir o que é melhor para si, quais são suas prioridades, desejos e escolhas.

Assim, no momento em que uma mulher dá a luz ela deixa para trás algumas coisas e tem que enfrentar outras, ou seja, uma mulher morre enquanto nasce uma outra, inevitavelmente. Independente das respostas em relações às perguntas anteriores, a nova mãe terá que lidar com uma nova fase em sua vida, com outras responsabilidades e sentimentos.

"Pouco depois, deu à luz a uma filha que tinha a cútis tão alva como a neve e tão corada como o sangue, e cujos cabelos eram negros como o ébano, e ficou chamando Branca de Neve. E, quando deu à luz a criança, a rainha morreu.” (GRIMM, J. \& W. 2000: 358)

A mãe de Branca de Neve deseja muito uma filha, uma menina que fosse "branca como a neve vermelha como o sangue e negra como caixilho da janela", e assim nasce seu bebê e este é o momento da verdade, de encarar seu desejo realizado frente a si mesma e descobrir se ele seria sua fonte de felicidade e realização ou um território desconhecido a ser explorado e domado. Em ambos, os casos a mulher nunca mais será como a que era antes da maternidade.

Se uma mulher morre, então outra deve tomar o lugar da anterior, e no caso do conto aqui analisado, quem entra em cena é uma madrasta, ou seja, uma mulher que não ama os seus enteados, mas apenas aqueles que compartilhavam seu próprio sangue, seus filhos. Mas, no caso de Branca de Neve, seu pai não tem filhos com a nova esposa, o que não impede o desprezo sentido por essa pela enteada.

"Sua segunda mulher era bela, mas altiva e orgulhosa, não admitia que nenhuma outra mulher fosse mais formosa do que ela.” (GRIMM, J. \& W. 2000: 358)

Essa nova mulher que surge no lugar daquela que deu à luz ao bebê, não será uma mulher carinhosa, bondosa, generosa e protetora como socialmente se esperado de uma boa mãe, ao contrário ela será perversa, competitiva e cruel com Branca de Neve, como uma rival na disputa de um precioso prêmio. A nova rainha, a madrasta, é a figura que preenche o lugar materno, porém justamente por não ser a mãe biológica, ela pode apresentar as características vis de qualquer mulher.

A figura materna é uma das mais fortes e consolidadas em relação a virtudes e pureza. A mãe segue no coletivo imaginário como aquela que apenas faz o bem, que 
acolhe, protege e despoja-se de tudo em favor de seus filhos. Ela é incapaz de cometer qualquer ação que desfavoreça, prejudique ou cause injustiça aos seus herdeiros; ela somente nutre bons sentimentos, nunca inveja e ciúme de seus filhos. A mãe realiza-se com a felicidade de seus filhos e desespera-se com seus infortúnios.

Porém, a maternidade não é um dom que simplesmente acontece com todas as mulheres grávidas ou um papel fácil a ser desempenhado, que a partir do momento em que a mulher torna-se mãe ela deixa todos seus vícios, fraquezas e defeitos para trás e eleva-se a um nível em que a transforma em um ser humano infalível, que nunca comete erros.

Por isso, a figura da madrasta é tão importante nesta narrativa, porque a figura que ocupará o lugar da mãe é aquela que pode e deve ter falhas, ela permite Branca de Neve crescer e florescer em sua beleza, ser uma jovem que entre em choque com a figura referencial feminina de dentro do lar. Há, então, espaço para o conflito feminino, a mulher mais velha pode mostrar seus sinais de insatisfação em relação a mais jovem.

A madrasta que possui muita beleza não se satisfaz com este fato - de ser muito bela - ela precisa ser a mais bela. Quando descobre que não o é passa a odiar a enteada que lhe superou em beleza e sente a necessidade de eliminá-la para voltar a ocupar seu posto de a mais bela entre todas as mulheres.

"Dize a pura verdade, dize espelho meu:

Há no mundo mulher mais belo do que eu?

E certo dia, o espelho respondeu:

Aqui neste quarto sois vós, com certeza,

Mas Branca de Neve possui mais beleza.

A rainha ficou lívida de raiva e inveja. E, desde aquele momento, odiou Branca de Neve.” (GRIMM, J. \& W. 2000: 358)

Pela ordem social da vida, os filhos devem superar os pais, tanto fisicamente quanto intelectualmente. Os filhos nascem despreparados para a vida e vão progredindo conforme os cuidados que recebem de seus pais, os jovens aprendem com os mais velhos, como também com suas próprias experiências, por isso, a tendência da vida é uma geração ser melhor que a anterior.

Sendo as protagonistas deste conto personagens femininas é evidente que os dramas desenvolvidos serão aqueles particulares ao mundo feminino. A inveja entre mãe e filha é um divisor de águas no mundo feminino, é neste momento que se delineia a separação entre mãe e filha, quando começam os conflitos comuns da adolescência. 
As vontades e as opiniões da jovem querendo prevalecer sobre a mulher mais experiente do lar, a sensação incômoda da mulher mais velha de não ser a mais requisitada, a mais importante neste ambiente; o aflorar de outra mulher enquanto ela mesma começa a perder seu vigor.

“O ódio foi crescendo em seu coração de tal maneira que ela não teve mais sossego: noite e dia invejava a beleza da princesinha, revoltava-se de ser menos formosa do que ela, não se resignava de modo algum.” (GRIMM, J. \& W. 2000: 358)

Conforme já citado anteriormente, um dos dramas femininos, muito comum e conhecido, é a vaidade. Esse sentimento atormenta as mentes de várias mulheres, traz o desejo ser a única a possuir os melhores atributos. Assim, quando a mulher não consegue desprender-se de sua vaidade e envolver-se com o mundo exterior, criar vínculos e desenvolver relacionamentos que não estejam baseados apenas em sua aparência, ela torna-se uma pessoa narcisista.

O mito de Narciso é de origem desconhecida, porém permeia não apenas os campos artísticos, como pintura e literatura, mas também a psicanálise, em que descreve a patologia do indivíduo extremamente voltado para si mesmo. Esta personagem mostra alguém extremamente belo que recusa todas investidas de enlaces sentimentais das outras pessoas. Narciso acredita que ninguém possua beleza ou atributos a sua altura e recusa-se a relacionar com qualquer um que se aproxime, e termina castigado apaixonado por seu próprio reflexo, levando-lhe a morte.

O mito de Narciso descreve um jovem orgulhoso que permanece insensível ao amor, razão a qual lhe leva ao fim, já que ele não foi castigado por ser o mais belo, por ser alvo de inveja, mas por acreditar que era superior em qualidades a todos a sua volta, e ninguém seria digno de seus atributos. Narciso é castigado por acreditar que poderia manter-se sozinho no mundo, que era tão superior que não precisaria compartilhar das mesmas leis dos outros humanos e se entregar pelo amor a alguém.

Pessoas narcisistas podem sofrer demasiadamente, pois são incapazes de enxergar os próximos e acreditam que são únicos e bastam tanto a si mesmos, como aos outros que o rodeiam. Porém, a natureza humana é fugaz, ninguém pode permanecer eternamente o mais belo, o mais jovem, o mais atraente, o mais esperto, o mais poderoso ou qualquer outra coisa por toda vida, já que para ser ou ter mais que alguém 
ou alguma coisa precisa-se ter um ponto de comparação. Quando há comparações, há sempre as chances de ser superados.

Uma mãe narcisista compete e desgasta-se muito com sua filha, pois ela não consegue abrir mão de sua vaidade e criar elos amorosos com a menina e ainda é obrigada a encarar sua fugacidade ao acompanhar o crescimento e desenvolvimento da menina em mulher.

Como acontece essa transição? Quando a mulher mais velha percebe que a mais jovem está a suplantando em qualidades? Este momento acontece em seu quarto, sozinha com seu espelho que lhe anuncia a verdade. O espelho possui um papel muito importante já que ele desempenha tanto os olhos alheios, quanto a consciência e autocrítica da madrasta.

O espelho, como os olhos alheios, enxerga a beleza de ambas; mas concluem que a da mais jovem é maior, pois ele é a fonte de comparação, o parâmetro indicador da mais bela. Como definir a maior beleza se não por meio da comparação? Não há outra maneira, o reflexo do espelho é o julgamento alheio sobre quem somos, a opinião que os outros têm de nós, a definição que fazem de nós. Por isso, muitas vezes, não basta ser bonita ou inteligente, tem-se necessidade de ser a mais bonita, mais inteligente para sentirmos seguras e bem conosco mesmas.

Há, também, o olhar voltado para si mesmo, aquele que cobra-se a beleza imutável. Há o desejo de permanecer jovem e atraente, de continuar sendo desejada, de ser o ponto de referência de beleza, afinal não é apenas o físico que está em jogo, o que está também julgamento junto à beleza são as virtudes, pois outra imagem coletiva é que mulheres bonitas possuem muitas qualidades.

Entretanto, qual olhar que realmente interessa às mulheres desta estória? Seria mesmo o do espelho mágico, qualquer olhar alheio? Na verdade, o olhar disputado entre as duas personagens femininas é o único olhar masculino do lar - o Rei - o marido e pai, o primeiro referencial e julgamento masculino na vida da filha e o mais importante na vida da esposa. O espelho também representa o olhar masculino deste lar que, a partir do momento no qual passa a enxergar a beleza da jovem, provoca na madrasta a inveja e ódio, pois ela espera e deseja ser a figura feminina principal na vida deste homem. Tais sentimentos são incontroláveis, a ponto de se pensar em eliminar sua rival.

Este é um momento muito delicado do universo feminino, aquele em que mãe e filha percebem-se às portas de uma mudança grande em suas vidas. Na verdade, a mãe, como mulher mais experiente, tem maior consciência da mudança que está prestes a 
acontecer: a transformação de uma menina em mulher. É o momento que a mãe deve abrir mão de sua filha e deixá-la caminhar sozinha, em que a mulher mais velha percebe que já cumpriu seu papel de mãe, de referência formadora, e deixa a jovem livre para tornar-se a mulher que escolheu ser.

A filha, mais jovem e ainda imatura e insegura, não entende e não consegue assimilar corretamente todos os sentimentos que brotam neste momento, gerando muitas vezes ela mesma o desconforto na relação filial. A jovem pode sentir culpa ou vergonha por ter ciúme e inveja de sua mãe, já que esta é ou tem tudo aquilo que a menina ainda não pode ou consegue alcançar. O adolescente desenvolve então um mecanismo para não se sentir mal em relação aos pensamentos que tem de seus pais, os filhos imaginam e acreditam que na verdade são os pais que competem com eles, que tem inveja e ciúmes deles.

Se pode haver pais narcisistas que realmente competem com seus filhos, por valorizarem apenas aparências; há também aqueles que realmente relacionam-se com seus filhos e criam laços amorosos com eles. Em outras palavras, na maior parte das vezes os pais não competem com seus filhos, pois já são experientes e maduros o suficiente para entenderem que para cumprir bem seus papéis, eles devem estimular e auxiliar seus filhos.

Por mais doloroso que seja para uma mãe dar-se conta que está envelhecendo e que deverá encontrar outro lugar para ocupar na vida de seus filhos, ela inevitavelmente entende sua situação, e se ela é uma boa mãe, ela não consegue retardar essa mudança ou sabotá-la, ao contrário, ela cooperará para tal, impulsionará para o mundo seus filhos.

"Afinal, um dia chamou um caçador e disse-lhe:

_ Leva a menina para a floresta, bem longe. Não suporto mais vê-la perto de mim. Mata-a e, como prova que cumpriste a minha ordem, traze-me o seu pulmão e o seu fígado.” (GRIMM, J. \& W. 2000: 360)

No conto, vemos que a madrasta não pode mais controlar o olhar do espelho o tempo todo, mesmo que ele esteja trancado em um quarto, ele consegue enxergar a beleza aflorando em Branca de Neve, pois a beleza e encantos da madrasta não são perfeitos e hipnotizantes. E é assim que deve ser na vida das mulheres, a mãe (ou a primeira referência feminina de uma menina) deve ter atributos interessantes para que sirvam de identificação e pontos de partida para a nova mulher que nascerá em breve. 
Não algo tão perfeito que no máximo só possa ser copiado, para conseguir algum espaço ou atenção aos olhos dos outros que a cercam.

Do ponto de vista da psicanálise, a menina deve em um determinado momento de sua vida odiar sua mãe, romper totalmente com ela para construir sua própria personalidade. Ela deve deixar de enxergar sua mãe como única fonte de alegria e identificação, algo tem que romper seus elos para que a menina possa construir outros com outras pessoas, inclusive seu pai, a primeira referência do sexo oposto de sua vida.

“A relação com a mãe é a mais importante na vida de todas as pessoas; mais do que qualquer outra, ela condiciona o desenvolvimento inicial da nossa personalidade, afetando em grande escala nossa visão futura de vida e de nós mesmos.” (BETTELHEIM, B. 2003: 259)

É o momento em que as relações familiares começam a tomar novos rumos. A mãe deverá aprender a compartilhar as atenções de seus filhos com o marido, o pai deverá envolver-se mais e compartilhar intimidades com seus filhos, enquanto que os filhos deverão começar a se desligarem da figura materna para identificarem-se com a figura paterna, este é o momento quando os filhos começam aprender a se relacionar com outros seres-humanos.

"A criança começa a sentir-se uma pessoa, um parceiro significante e significativo numa relação humana, quando principia a relacionar-se com o pai. Só nos tornamos pessoas quando nos definimos em oposição à outra pessoa. Como a mãe é a primeira e, por algum tempo, a única pessoa na nossa vida, uma autodefinição rudimentar se inicia com uma definição frente a ela. Mas, devido à profunda dependência da mãe, a criança não pode encaminhar-se para uma autodefinição, a menos que conte com uma terceira pessoa.(BETTELHEIM, B. 2003: 259)

Esta mudança é mais suave na vida dos meninos, pois é muito mais tranqüilo para eles desligarem-se da mãe e se identificarem com pai, que é alguém que eles se tornarão na vida adulta, um homem. Mas para as meninas isso é mais difícil. Afinal, como se identificar com alguém que não é nem semelhante fisicamente consigo mesma? Assim, a menina para começar a interessar-se por seu pai, ela tem que achar sua mãe não mais tão interessante, de certa forma, a mãe tem que repeli-la para que esta possa olhar para o pai e encontrar algo que se identifique e construir um relacionamento com ele também. 
"Um passo necessário para a independência é aprender que "Eu posso contar com outra pessoa além de mamãe" antes de podermos acreditar que podemos lidar com as coisas sem depender de ninguém.” (BETTELHEIM, B. 2003: 260)

"Sempre claramente diferenciada da genitora, a mãe sobrevivente é essa madrasta, em cuja relação com a enteada não há o amor materno para amortecer o ciúme e a inveja.” (CORSO, D. \&M. 2006: 78)

Nessa transformação da vida seriam a inveja e o ciúme da mãe maiores, ou a filha os sentiria com mais intensidade? Podemos enxergar esse ódio demonstrado pela madrasta como uma representação da tentativa de desligamento da menina com a mãe. Nesta fase de crescimento, a filha precisa abandonar toda sua dedicação e carinho dados à mãe para começar a desenvolver outro tipo de relacionamento, o amor ao sexo oposto, neste caso, com o pai. Evidentemente, este primeiro relacionamento não deverá ter um cunho sexual, porém servirá de rudimentos para que futuramente a jovem possa relacionar-se com um homem.

Este processo na vida das mulheres, tanto nas experientes mães, quanto nas jovens filhas é muito delicado e muitas vezes sofrido, já que este é o momento em que as meninas terão que negar suas mães para tornarem mulheres com uma identidade própria, e as mães sofrem por perceberem que não influenciam tanto mais suas filhas e que perderam muito espaço em suas vidas.

Desta forma, percebemos porque é tão importante que não haja uma mãe no conto, mas sim uma madrasta bruxa que repele a jovem da casa, que a joga no mundo, que trama e prepara armadilhas para ela, pois esta mulher pode fazer malvadezas e ser odiada, enquanto que a mãe, não. Na vida real é isso que acontece, as mães deixam de ser o alvo de toda a atenção das meninas, iniciam-se os conflitos e as meninas tentam ligar-se mais ao pai, procurando ter os mesmos interesses que eles, agradando-os; enfim, criando novos elos com o pai.

Levando-se em conta que o embate que deverá ser resolvido é entre mãe e filha, ambas buscam se ambientar em uma nova ordem da vida, as transformações causadas pela maturidade feminina, e isto apenas elas podem fazer, nenhum homem pode lhes dar a chave para a entrada nesta nova fase para ambas, assim as participações masculinas acabam sendo mesmo reduzidas.

No conto, vemos que o papel masculino é preenchido pelo Rei, o espelho mágico e o caçador, todos eles dividem as tarefas de esposo e pai, um divide os aposentos da madrasta e o outro protege Branca de Neve. Os papéis masculinos não 
possuem um grande destaque na narrativa, justamente por tratar profundamente das mudanças dos relacionamentos e papéis no universo feminino, por isso os homens desempenham pequenas aparições.

O Rei logo é suprimido no início do conto, dando espaço mais adiante um espelho mágico, depois um caçador e posteriormente os anões. Todos eles são as facetas do homem da casa, ele pode ser encontrado no quarto da esposa, depois, obedecendo desejos dessa, pode ainda estar protegendo a menina de grandes perigos ou a acalentando na vida cotidiana.

Quanto ao papel de protetor exercido pelo pai, pelo menos ao que se é esperado socialmente, este é desempenhado no conto pelo caçador e anões, que apesar de proteger a bela jovem da ira da madrasta, nada podem fazer quando a menina está longe de suas vistas ou parte para o mundo, neste caso a floresta. Isso nos mostra que a proteção paterna possui limites para agir, que no lar o pai sempre estará pronto a proteger sua filha, mas que fora dele esta deverá conseguir agir adequadamente e sozinha diante as dificuldades da vida

“-Não me mates, caçador! Prometo entrar cada vez mais pela floresta e nunca mais voltar para casa!

Vendo-a, tão bela e tão jovem, o caçador teve pena e soltou-a, dizendo-lhe:

-Foge, foge, pobre criança!

E acrescentou, baixinho, sem que ela ouvisse:

-As feras não tardarão a devorar-te.” (GRIMM, J. \& W. 2000: 360)

O pai é também o marido, ele também tem compromissos com a esposa; neste caso, a madrasta. Entretanto, por mais cruel que pareça o desejo da esposa e mais absurdo ainda o homem cumpri-lo, na verdade esta é forma em que a mãe está ajudando a menina desvincular-se dela e ainda aprender a confiar no seu pai, que mostrará compreender seus medos.

Para uma jovem adolescente, este momento aparece terrivelmente solitário e angustiante, pois ela sente-se rejeitada pela mãe e ainda não confia em seu pai, ela não consegue ainda identificar quais são seus problemas, o que ela precisa buscar especificamente, afinal se ela soubesse era sinal que já estaria madura, já seria uma mulher. Agora, a filha precisa descobrir qual é a posição que ocupa no lar, como ela deve se colocar no relacionamento com os pais e também no mundo. 
Entretanto, por mais sozinha e abandonada que a menina acredite estar neste momento, ela irá lançar-se ao mundo com determinação e impulso, ávida por encontrar suas respostas.

"Enquanto isso, a pobre menina vagava pela floresta, apavorada, sem saber o que fazer, até que saiu correndo loucamente, entre espinheiros e pedras aguçadas. Não se feriu, no entanto, e caminhou enquanto teve força nas pernas.” (GRIMM, J. \& W. 2000: 360)

Para a jovem, o caminho em busca desse novo lugar no lar e no mundo é muito mais árduo que talvez ela espere, pois ela precisa adquirir novos conhecimentos por experiências individuais que muitas vezes são traumáticas. A menina precisa virar mulher e isto envolve uma nova série de responsabilidades e entendimentos, inclusive entre homem e mulher. É desta maneira que Branca de Neve encontra a casinha dos sete anões.

Lá ela encontra os anões, figuras masculinas que representam o pai, eles têm como função proteger Branca de Neve no novo mundo em que ela se lança, eles são apresentados como seres amistosos e carinhos que permitem que a jovem fique na casa em troca de seus serviços domésticos. Situação ideal para uma jovem mulher que precisa praticar seu papel feminino no lar, mas com o grande alívio de ser este um papel assexuado, já que o sexo exige uma maturação maior para ser exercido com segurança pela nova e jovem mulher.

Eles não cumprem todos os papéis de um homem, já que são apresentados como homens-crianças. Eles seriam homens em miniatura, que não apresentam desejos sexuais, mais são experientes para alertá-la dos perigos da vida e ensiná-la a evitá-los, eles ainda dão o sustento a casa, com seu trabalho de mineradores, ou seja, eles estão cumprindo o papel de um pai com sua filha adolescente.

Nesse novo lar, Branca de Neve não precisa lidar ainda com situações as quais na se sente inteiramente preparada. Lá os anões são apresentados como pequenos homens protetores, que a tratam com muito carinho e cordialidade, faz com que a jovem remeta-se à sua infância, há pouco abandonada. Com móveis e pessoas pequenas, é um lugar no qual pode fazer a transição da infância para vida adulta tranqüilamente, sem grandes impactos.

"E ficou morando com os anões. Tomava conta da casa com a maior boa vontade, mantendo tudo limpo e bem arrumado. De manhã cedo, os anões iam às 
montanhas para minerar, retirando cobre e ouro das galerias que abriam na terra. Voltavam no fim da tarde, e o seu jantar tinha de estar prontinho quando chegavam em casa.” (GRIMM, J. \& W. 2000: 362)

Outro aspecto apresentado no relacionamento dos anões com Branca de Neve evoca uma importante parte da vida adolescente, na qual os jovens sentem-se apenas à vontade entre seus pares, pois assim evitam os conflitos surgidos no seio familiar, muito comuns neste período. Os anões e Branca de Neve tratam-se como iguais, apesar de ela ser uma jovem princesa e eles adultos. Esta é a fase que a jovem comece a senti-se mais segura, é o momento em que ela começa a arriscar-se em ligar-se a outros homens, a relacionar-se com rapazes.

Essa tranqüilidade e sensação de comodidade em sua vida dura pouco, já que a madrasta descobre o paradeiro de Branca de Neve e parte para o ataque. Para tanto, ela usa o disfarce de uma velha vendedora de maçãs, diz que não precisa entrar na casa da moça e lhe dá a metade mais vermelha da maçã, comendo a outra metade que não era tão apetitosa. Ganha a confiança de Branca de Neve, que também come seu lado da maçã e imediatamente cai como morta no chão.

A madrasta chega até Branca de Neve em um disfarce de velha, ela busca a confiança da moça, para ser ouvida e atendida. Os velhos não inspiram perigo, pois não possuem mais a vitalidade e a força da juventude, mas em contrapartida, são sábios e apaziguadores em suas ações. No velho, o jovem pode encontrar resposta e conforto em meio aos seus conflitos, o velho nunca é uma figura temida ao contrário muito bem recebida por todos.

Entretanto, por que a madrasta ainda queria eliminar sua rival, mesmo estando essa afastada de sua companhia? O espelho não a deixava esquecer que sua beleza perdia o seu vigor, enquanto a da jovem crescia, e isso precisaria ter fim? O término deste percalço na vida da madrasta viria com a morte de Branca de Neve?

Mais uma vez, a madrasta intervém na vida de sua enteada de forma aparentemente negativa, a jovem entende ou sente-se ameaçada novamente com a presença da figura feminina mais experiente, de tal forma que a jovem sente sua vida sendo suspensa.

Quando a moça começa a desenvolver relacionamentos com pessoas do sexo oposto, ela pode mais uma vez sentir-se insegura e ter inveja de sua mãe, que já é uma mulher com todas as ferramentas e conhecimento para circular neste universo ainda tão complicado para jovem, o dos relacionamentos amorosos. Ela ainda não sabe como se 
comportar, o que ela deve esperar receber e dar em um relacionamento amoroso. Por isso a figura da madrasta volta à tona mais uma vez, para impulsionar a enteada nessa nova fase da vida.

A mulher mais experiente tem de ensinar mais uma vez a mais jovem, e para tanto ela sabe que deve aproximar-se de forma a não levantar suspeitas na mais jovem, que ainda acredita estar em uma competição de quem é a melhor mulher. No conto, vemos a madrasta encontrar Branca de Neve como uma simpática senhora, que deseja compartilhar uma maçã com ela, a qual a moça aceita de bom grado.

Este é o momento em que a mulher mais velha e mais experiente ajuda no despertar da sexualidade na mais jovem. A madrasta acaba por uma vez com a infantil Branca de Neve, dando-lhe a maçã; ela divide seu conhecimento com a jovem, entretanto, essa interação não significa que haja compreensão imediata daquilo que está sendo mostrado à jovem. Talvez, seja por isso, que esse símbolo tenha sido escolhido ou o tenha sobrevivido na narrativa, pois a maçã acolhe significados muito importantes e pontuais para essa fase de vida e transformação da mulher, como podemos averiguar pelo verbete do dicionário de símbolos:

"Como forma esférica, significa uma totalidade. É símbolo dos desejos terrenos, de seu desencadeamento. A proibição de comer a maçã vinha por isto da voz suprema, que se opõe à exaltação dos desejos materiais. O intelecto, a sede de conhecimento é como sabia Nietzche - uma zona apenas intermediária entre desejos terrenos e a da pura e verdadeira espiritualidade.” (CIRLOT, J.E. 2005: 359)

A maçã tem também uma forte conotação sexual, principalmente quando é bem vermelha, parte que coube a Branca de Neve. A fruta nos remete a expulsão de Adão e Eva do paraíso por terem a mordido e descoberto todos os prazeres do sexo. A parte vermelha da maçã ingerida por Branca de Neve simboliza fase em que a mãe prepara sua filha para uma parte importante no ser mulher, o relacionamento sexual.

Esta fase é também muito delicada, em que a jovem sente-se muitas vezes sufocada com as preocupações maternas. A mãe, por sua própria vivência, sabe que a sexualidade feminina envolve diversas complicações, pois é exigido da mulher maturidade, equilíbrio e segurança para que ela possa encontrar nesta área realização e felicidade. A moça precisa conhecer e saber quais as responsabilidades, prazeres e conseqüências de uma vida sexual, como também, das expectativas que pode ter na vida conjugal. Ela precisa adquirir a consciência completa de como é relacionar-se com o sexo oposto da maneira mais íntima. 
A tensão que é gerada nesta fase é grande, pois a filha acredita que já está madura o suficiente, que já entende tudo sobre o jogo da sedução, o que esperar de um relacionamento com o sexo oposto, baseando-se nos seus relacionamentos juvenis com outros rapazes; o que fica muito aquém dos que ela se envolverá na vida adulta. Por isso, mais uma vez a jovem sente-se oprimida pela mãe e tem raiva dela, por essa estar tentando mostrar, encaminhar, ensinar-lhe quais aspectos importantes em que a jovem deve reter-se; a mãe não despreza o conhecimento adquirido pelas próprias experiências da filha, ela já sabe que eles não suficientes para se tornar com sucesso uma mulher.

"A maçã fora preparada com tanta habilidade, que só a parte que tinha a casca vermelha foi que ficou envenenada. Branca de Neve olhou para a maçã e seu aspecto era tão apetitoso, que fazia realmente dar água na boca. A menina não resistiu muito: enfiou a mão pela janela e pegou o pedaço de maçã. Mal levou o pedaço à boca, caiu morta.” (GRIMM, J. \& W. 2000: 364)

Quando o terreno é preparado cautelosamente pela mãe para atrair a atenção e confia de sua própria filha, para que ela possa dividir com a jovem aquilo que lhe falta para tornar-se uma mulher. Esse é o momento em que a jovem passa por conflitos e elaborações internas para ter a compreensão do conhecimento compartilhado pela sua mãe, e assim ter as condições necessárias para tomar e adaptá-lo para si mesma, aplicar esse conhecimento conscientemente em sua vida.

"Quando voltaram para casa naquele dia, os sete anões encontraram Branca de Neve estendida no chão, imóvel, sem respirar: estava morta. Eles não se resignaram, porém, com aquela desgraça. Carregaram-na, procuraram por todos os modos animá-la, com massagens sinapismos. Em vão, não adiantava esforço algum. Tiveram de colocála em um esquife e todos os sete sentaram ao redor, chorando sem parar durante três dias.” (GRIMM, J. \& W. 2000: 366)

Branca de Neve fica como morta em um caixão de vidro com a aparência viva. Ela é coloca no alto de uma montanha pelos anões, que a observam todos os dias mas não entendem o que se passa com a linda jovem. Até o momento em que é encontrada por um príncipe que apenas ao vê-la, apaixona-se. Esta é a passagem em que Branca de Neve tornará uma mulher, ela irá se separar de sua antiga vida com os anões e seguirá em uma nova com o príncipe.

A filha juvenil despede-se de seu pai que, apesar de entristecer-se em vê-la crescer, sabe que não há como impedi-la de tornar-se uma mulher. O pai, diferentemente da mãe, não acompanha tão conscientemente o crescimento da filha, ele 
não consegue enxergar as várias nuances que há no desenvolvimento feminino, seus olhos não são tão atentos como os da mãe, por isso quando ele percebe que sua filha está se transformando em uma mulher, ele assusta-se e tenta adiar este momento, porém percebe rapidamente que é incapaz de lutar contra a natureza e tempo, deixando assim a filha seguir seu caminho no amadurecimento.

"E falou aos anões:

-Deixai-me levar o caixão, que vos darei em troca o que quiserdes.Os anões, porém, responderam:

-Não nos separaremos dela nem em troca de todo o ouro que há no mundo!

-Dai-me, então, como um presente, pois não posso viver sem ver Branca de Neve - insistiu o príncipe.

-Velarei por ela como o meu bem mais precioso.” (GRIMM, J. \& W. 2000: 367)

O pai sentirá melhor se sua filha encontrar alguém que cuide e ame ela, como ela foi e é no seio familiar. Assim, não basta um príncipe surgir e apaixonar-se por Branca de Neve; ele precisa merecê-la, ele precisa respeitá-la e desejar-lhe como uma mulher, como uma pessoa com desejos e expectativas, ela precisa ser aceita e amada como ela realmente é. Quando um homem pode entregar-se desta forma a uma mulher e também acolhê-la por completo, ela será uma mulher completa, consciente de toda sua personalidade, pois ele estará fechando o último ciclo juvenil em sua vida e começando um novo com ele em sua vida adulta.

Nesse último ciclo da vida juvenil, a jovem passará por um tempo com diversas dúvidas e angústias, mantendo-se por um tempo alheia e afastada do mundo; ela estará voltada muito para si mesma, solucionando e colocando em ordem suas questões pessoais, definidoras da mulher que nascerá em breve, por isso ela só pode abrir-se com alguém que se sinta segura, que ela perceba que tem paciência, compreensão e consideração por ela, alguém que não a apresse nos momentos de aflição, mas que esteja ao seu lado para ampará-la.

“(...) e o esquife quase caiu, e balançou tanto que o pedaço envenenado de maçã que havia comido saltou para fora da garganta de Branca de Neve, onde estava atravessado. E logo em seguida ela abriu os olhos, levantou a tampa de vidro do esquife e sentou-se, viva e bem disposta.

_Onde estou, meu Deus do céu? - gritou.

_Estás comigo! - exclamou o príncipe, (...)_Amo-te mais do que qualquer coisa no mundo. Vem comigo ao palácio de meu pai. Serás minha esposa. (GRIMM, J. \& W. 2000: 367) 
Branca de Neve caminha para uma nova e primeira etapa na vida de uma mulher, o estar e manter um relacionamento amoroso realizador e prazeroso. Quando a mulher já tem definida sua personalidade, conhecendo assim suas qualidades e defeitos, ela já está pronta para doar-se a outro, a manter um relacionamento amoroso com um companheiro, pois ela já sabe como e o quê compartilhar e receber de um homem.

Ainda há um último encerramento na vida da menina para ela ser essa mulher, livrar-se de vez da figura referencial feminina, a mãe. A mulher precisa queimar essa ponte que a levou de um estágio a outro, para não correr o risco de quando surgirem as inseguranças e problemas da vida, ela não acabe voltando e infantilizando-se, percorrendo um caminho que não a fará melhor.

"Já haviam sido levados ao fogo sapatos de ferro, que foram trazidos seguros por tenazes e colocados diante dela (madrasta), que teve de calçá-los e dançar até cair exausta e se estorcendo de dor. Deu o último suspiro, junto com o qual saiu também sua alma, em direção ao inferno.” (GRIMM, J. \& W. 2000: 369)

Pronto, Branca de Neve está agora segura o suficiente para seguir com sua vida, ela sabe que não pode mais retornar à casa materna, mais que isso, ela não cortou simplesmente os laços com sua referência feminina, a madrasta, ela firmou tão bem sua personalidade, ela se conhece tão bem e profundamente agora, que sabe que nunca mais recorrerá a ela, Branca de Neve é mulher livre e independente.

Ao final dessa análise, percebe-se que a madrasta não é tão má assim, na verdade ela chega a ser uma heroína. Sabe que tem de fazer sua filha odiá-la para que a jovem consiga construir seu eu interior, sua própria personalidade. A madrasta é falível e passa também por momentos de insegurança, porém seu lado materno, o que faz colocar a prole acima de qualquer sentimento ou necessidade própria, supera os sentimentos da simplesmente da mulher. A madrasta efetivamente ajuda a Branca de Neve tornar-se uma mulher.

\section{2) "A mulher e a filha bonita" compilada por Sílvio Romero.}


Esse conto é sobre uma viúva muito bela que tem uma mais bela ainda, fato que gera uma profunda inveja na genitora, chegando ao ódio. No conto as personagens não têm nomes ou uma descrição física ou psicológica, são identificadas apenas por substantivos comuns: mulher, filha, negro velho, feiticeira ...

A narrativa conta que essa viúva desesperada com a atração que a beleza da filha causava em todos homens que a viam, tenta trancá-la em casa e falhando esse artifício e já com ódio de sua filha, ela pede a negro velho que trabalha na casa, levasse a menina para o mato e lá a matasse.

O negro levou a moça, porém ficou com pena de matá-la, deixando-a sozinha no mato, voltou à casa com a ponta de uma língua de cachorra, dizendo a mãe que havia matado a moça. Entregue a sua própria sorte, a moça anda pelo mato e sobe em uma árvore alta, e de lá enxerga uma fumacinha, vinda provavelmente de uma casa.

Depois de muito andar, a moça encontrou um grande palácio no qual entrou, mas não encontrou ninguém, apenas viu que tudo estava muito bagunçado e sujo, assim resolveu limpar e arrumar tudo para esperar os donos do lugar retornarem. Entretanto, quando os donos retornaram, a moça escondeu-se pois viu que o palácio pertencia ao Rei dos ladrões e sua tropa. Esses vendo a limpeza no palácio ficaram muito gratos e começaram a procurar quem havia feito aquilo.

A moça encantou a todos os ladrões com sua beleza e eles já começaram a brigar entre si para saber quem ficaria com ela, não chegando a nenhum acordo o Rei dos ladrões propôs que ficasse morando com eles como uma irmã. E assim fizeram, e a moça pôde viver ali sossegada.

Mas com o passar do tempo, chegou aos ouvidos da mãe que a filha estava viva e muito bem, porque vivia em um palácio e estava muito rica. Ao saber disso, a mãe mandou chamar uma feiticeira para que procurasse sua filha e lhe desse fim. A feiticeira aceitou a proposta e foi até o palácio dos ladrões. Chegando lá, a feiticeira encontrou a moça sozinha, aproveitando essa chance a velha fez uma grande festa à moça, dizendose ser sua avozinha que lhe trazia um presente humilde: um parzinho de sapatos.

A moça aceitou por educação e calçou-os então, porém assim que o fez caiu para trás como morta. A feiticeira tratou de correr de lá, deixando a moça enfeitiçada. Os ladrões quando retornaram e viram a moça naquele estado ficaram muito tristes e a colaram em um caixão com muito dinheiro e uma recomendação a quem encontrasse-a, que a enterrasse em solo sagrado, já que eles não podiam ir à cidade para enterrá-la. 
Um filho do rei, que andava caçando, encontrou o caixão da moça e ao vê-la ficou tão apaixonado que não a enterrou, mas a levou para seu palácio juntamente com todo dinheiro que estava com ela. O príncipe colocou o caixão da moça em seu quarto e não permitia que ninguém entrasse ali; e a cada dia que se passava, a paixão dele aumentava, porém a moça continuava a dormir.

Um certo dia, enquanto o príncipe estava afastado caçando, sua irmã entrou em seu quarto e descobriu a moça e toda sua riqueza, porém achou estranho ver tão bela e rica moça com sapatos tão feios e pobres e os tirou. Nesse momento, a moça acordou e sentou-se pedindo água. A princesa lhe deu água e calçou-lhe novamente os sapatos na moça, que imediatamente voltou a dormir.

Quando o príncipe voltou da caça, sua irmã lhe propôs um acordo: em troca de todo o dinheiro que ele havia achado ela desvendaria um segredo do quarto dele. $\mathrm{O}$ príncipe concordou e a princesa desencantou a moça. Houve então uma grande festa de casamento para o casal, e nove meses mais tarde a moça dava a luz a dois lindos meninos.

Entretanto, quem veio ser sua parteira foi a feiticeira que trocou seus filhos por um sapo e uma jia e os apresentou ao rei como seus netos. O rei mandou um recado ao seu filho, o príncipe, ausente por causa de uma guerra, contando-lhe sobre as criaturas que haviam nascido da moça. O príncipe manou dizer ao pai que matasse então a esposa. O rei teve pena da moça, assim cortou-lhe um seio e a expulsou de casa.

A moça saiu pelo mundo afora e como em um momento sentiu muita sede, parou em uma fonte e bebeu água; passou também a água no peito e seu seio voltou a crescer. Continuou sua viagem, chegando à casa de um gigante, aonde hospedou-se, porque lá estavam seus dois filhos, pois a feiticeira havia os colocado lá.

Muito tempo depois, andando em suas caçadas, o príncipe encontrou com seus filhos e acabou se afeiçoando a eles, sem saber quem realmente eram. Assim sempre que o príncipe saía para suas caçadas, passava na casa do gigante para visitar os meninos, e em um desses dias, ele acabou vendo sua esposa. Arrependeu-se do que havia feito e tornou a viver com ela, mandando matar a feiticeira.

Nesse conto, recolhido por Sílvio Romero da cultura popular brasileira e classificado como de origem européia, muitos anos após a compilação dos irmãos Grimm podemos notar a repetição da temática de Branca de Neve, da menina que procura e encontra sua identidade, tanto pessoal como social, e transforma-se em mulher. Entretanto, nesse conto a diferença está no seu desfecho, enquanto em Branca 
de Neve a estória acaba logo após o casamento da protagonista, em A mulher e a filha bonita existe uma narrativa da vida conjugal da protagonista.

O olhar masculino, ou melhor, o papel masculino está mais presente com uma maior participação, pois no conto há a narrativa das peripécias vividas pela protagonista após o enlace matrimonial, há uma apresentação das relações conjugais, do envolvimento de indivíduos cujas origens provavelmente encontram-se em núcleos familiares de valores e costumes diferentes.

Assim, nesse conto, as reações das personagens masculinas terão maior importância no desencadeamento das ações das personagens femininas, já que a narrativa irá tratar de acontecimentos após o matrimônio, do relacionamento de homem e uma mulher, sendo aqui a protagonista feminina, então todas as ações da personagem masculina são relevantes, pois é a partir delas que a protagonista terá suas reações.

Antes de analisarmos os fatos ocorridos na convivência conjugal da protagonista, da sua vida com um indivíduo do sexo oposto externo ao seu primeiro nuclear, vejamos primeiramente as peripécias vividas dentro do seu lar e a saída dele: logo no início da narrativa já fica estabelecida a relação de rivalidade e inveja da mãe em relação à filha.

"Uma vez havia uma mulher viúva que tinha uma filha muito bonita, e a mulher também era muito bela e tinha inveja da filha." (ROMERO, Sílvio. 2002:213)

Não há sugestões ou divagações sobre o sentimento que transita na relação entre mãe e filha, ele já é explicitado logo no primeiro parágrafo do conto, mostrando que haverá um choque ou uma disputa entre as duas. O juiz dessa disputa é o olhar, é o desejo masculino, pois são as personagens masculinas que definem e decidem quem é a mais bela, as personagens femininas não se colocam ou se definem. Elas esperam que os homens façam isso, mas quando o veredicto é apresentado, aquela que é desfavorecida pela apreciação masculina sofre com o ressentimento e ódio àquela que saiu favorecida.

"Um dia, passando em casa dela uns viandantes, a mulher lhes disse: "Os senhores já viram uma cara mais formosa do que a minha?"Eles responderam: "É muito bela; mas a sua filha ainda é mais." A mulher ficou desesperada e foi tomando ódio à filha." (ROMERO, Sílvio. 2002: 213) 
A temática dessa narrativa é o florescimento de uma mulher, quais são os caminhos e percalços de uma menina até tornar-se uma mulher, sendo assim a insegurança diante as mudanças e incertezas desse período surgem nas entrelinhas do conto. A mulher mais velha não consegue mais manter seu controle e poder sobre os homens, não é mais tão bem avaliada pelo sexo oposto, ela percebe que está perdendo lugar a uma jovem, essa percepção, esse reconhecimento da mulher mais velha é muito importante, pois indica que a moça já é ou está tornando-se uma mulher. Para sabermos quem somos, muitas vezes, precisamos primeiramente do reconhecimento de nossos iguais.

"A madrasta invejosa dos contos de fadas tem uma função extra, ela reconhece a supremacia da beleza da mais jovem. Se nos referimos à madrasta, compreendemos que agora se trata de uma disputa entre mulheres, em que a jovem ganha um lugar na categoria, e a inveja da mulher mais velha é testemunha da importância dessa conquista." (CORSO, D. \& M. 2006: 113)

Como em Branca de Neve, a jovem também construirá sua personalidade para se tornar uma mulher conforme as indicações e expectativas daqueles que a circundam. O indivíduo busca não apenas adaptar-se ao ambiente, como também, aos seus semelhantes; nossa personalidade é construída conforme nos colocamos no contexto social e interagimos com o mundo a nossa volta. As exigências nos apontarão as diretrizes através das quais faremos determinadas escolhas e, os caminhos então percorridos, mostrarão quem somos.

Crescer e amadurecer são processos tanto individuais quanto coletivos: individual, pois cada pessoa terá a sua própria maneira de reflexão e entendimento do mundo; e, coletivo, porque busca nos outros modelos ou inspirações para seguir, como também aprovação e aceitação de atos e escolhas.

Nessa narrativa, o primeiro embate que auxiliará na construção da personalidade da moça, será o com a mãe, que assume o mesmo papel de uma madrasta: má e invejosa. O segundo embate será com a feiticeira, um desdobramento da figura materna e terceiro embate será com a personagem masculina, seu marido. Cada prova ou sofrimento causado por essas outras personagens à protagonista são as representações das transformações da vida.

"Cada conto de fadas é um espelho mágico que reflete alguns aspectos do nosso mundo interior, e dos passos necessários para evoluirmos da imaturidade para maturidade." (BETTELHEIM, B. 2003: 348) 
Em um primeiro embate, a protagonista terá então sua posição de mulher reconhecida pelo ciúme e inveja da mãe, mas no segundo embate a Filha terá que afirmar isso para indivíduos do sexo oposto, primeiramente ao negro velho imbuído de matá-la e, depois, o Rei dos ladrões e seu bando, que lhe dão abrigo.

A moça escapa da morte pela piedade do negro velho, que ainda engana a mãe com o pedaço de uma língua de cadela, deixando assim a moça longe do alcance da raiva materna. Porém, isso ainda não a faz uma mulher, ela precisará se colocar diante de outros homens, interagir como uma adulta.

Tanto nessa narrativa como em Branca de Neve, a protagonista ainda não está pronta para ser uma adulta, há uma fase de maturação entre a infância e idade adulta, isso não ocorre da noite para o dia ou muito menos, quando surgem oportunidades para tal, faz-se necessário várias experiências, muitas tentativas e erros para amadurecer.

Assim, aqui, nossa heroína encontra-se em uma casa cheia de homens adultos, que irão conviver com ela apenas como irmãos, mesmo que em um primeiro instante o desejo deles tenha sido diferente, tomá-la como esposa.

"Era um grande palácio, porém não tinha gente e estava muito sujo. A moça arrumou tudo, e varreu toda a casa, limpou os trastes e pôs-se lá à espera. (...) Os ladrões ficaram muito gratos e procurando por toda a casa a encontraram. A moça encantou a todos os ladrões pela sua beleza, e já eles queriam brigar para ver quem a tinha de possuir e sem a um acordo. Então o Rei dos ladrões propôs que a moça ficasse em casa morando com eles; mas que todos a tratassem e venerassem como se fosse uma irmã. Assim fizeram, e a mocinha ficou ali, descansada" (ROMERO, B. 2002: 214)

Essa situação provavelmente seja a ideal para qualquer moça que esteja começando sua vida adulta, pois nela vemos que a jovem será responsável por certos aspectos da vida, os afazeres domésticos ilustram algumas das obrigações e responsabilidades da vida adulta que precisam ser cumpridas, das quais a jovem já pode lidar e realizá-las com sucesso, porém um relacionamento adulto exige um passo maior, o qual ela não se sente ainda segura para dar.

Essa casa repleta de homens adultos que a desejavam, mas que a tratavam como uma irmã é a forma utópica que no início da vida adulta seria a mais realizadora e confortável, pois a moça não teria que lidar com aspectos sexuais, os quais ainda lhe são temerosos, já que dependem de maduração e segurança maiores. 
O relacionamento entre homem e mulher não surge assim que o desejo pelo outro é despertado, ele segue um caminho, um desenvolvimento, aqui está enfocado a desenvoltura feminina. A moça começa seu aprendizado em relacionamentos sentimentais de uma forma mais gradual, primeiramente ela insinua-se ao homem de forma a deixá-lo encantado, ligado a ela, exercendo certo poder sobre o outro, porém sem a entrega sexual. Essa posição é muito importante e enriquecedora, pois permite que a moça aprenda e desenvolva algumas práticas sociais do mundo feminino adulto.

Porém, esse lugar seguro só foi possível de se manter devido à intervenção de um homem mais velho, aquele que é respeitado pelos outros. O rei dos ladrões pode ser interpretado aqui como o pai da Filha, que a protege e a mantém uma certa distância dos outros homens, afinal é ele que não permite que os outros ladrões briguem para ficar com ela e ainda toma o cuidado de deixá-los apenas venerarem a moça.

Mas chega o tempo em que essa proteção não pode continuar, em que a moça deve seguir adiante no seu processo de amadurecimento, esse limite é dado por uma mulher. Agora, ao invés da mãe, surge a velha feiticeira para outro embate importante na vida da protagonista, pois será ela que forçará a saída do lugar seguro para o mundo.

A feiticeira aqui é uma extensão do papel materno, a mulher demonstra uma intimidade com a protagonista, que há um elo entre elas: "Oh! Minha netinha, há que tempo não te vejo! Tu mamaste nestes meus peitos! (ROMERO, S. 2002: 214).

Entre as mais diversas artimanhas ardilosas que a feiticeira poderia fazer para aproximar-se da moça, ela escolhe apresentar-se como avó e ama de leite da jovem, que não a estranha e aceita tranquilamente. Pode-se interpretar que essa feiticeira nada mais é que a mãe da moça, porém em idade mais avançada e mais experiente, pronta para cumprir seu papel orientador: incentivar e impulsionar sua filha a novas experiências na vida. Esse encontro abrirá um novo ciclo na vida da jovem. Ao calçar os sapatos velhos que a feiticeira lhe entrega, a moça cai em um sono profundo, parecendo estar morta.

"Quando os ladrões chegaram, acharam a moça morta e ficaram muito tristes. Pegaram nela, botaram num bonito carro e mais muito dinheiro e uma recomendação que quem a encontrasse, que enterrasse no sagrado, porque eles não podiam ir à cidade." (ROMERO, S. 2002: 215)

A jovem inicia uma nova etapa entregando-se a reflexão, ao aprofundamento de seus conhecimentos e a continuidade da formação de sua identidade. O sono profundo, parecido com a morte, representa a internalização de suas experiências 
anteriores; os sapatos velhos dados pela feiticeira seriam o conhecimento passado de mãe para filha, enquanto o dinheiro dado pelos ladrões seria as experiências acumuladas com outras pessoas, a convivência e aprendizagem com indivíduos não pertencentes ao seu núcleo familiar.

O início de uma nova etapa na vida de um indivíduo considerado normal leva-o a um estágio mais avançado que o anterior. Sendo assim, nossa protagonista deve assumir não apenas novas responsabilidades, como também, aprender a se relacionar com seus semelhantes como uma mulher adulta, a lidar com novas situações e sentimentos.

"Os contos de fadas sugerem que um dia teremos de aprender o que não conhecíamos antes - ou, colocando em termos psicanalíticos, teremos de desfazer a repressão sobre o sexo. O que vivenciamos como perigoso, repugnante, algo a ser evitado, deve mudar de aparência e ser vivenciado como verdadeiramente lindo. É o amor que permite que isso aconteça." (BETTELHEIM, B. 2003: 319)

Entretanto, como dito anteriormente, não é porque a ocasião se apresenta significaria que o ser humano já está pronto para lidar com ela ou resolvê-la. A moça está diante dessa nova situação: um homem que procura um relacionamento afetivo, com todas as implicações que esse exige; porém ela não desperta de seu sono e entregase ao príncipe, ela continua mantendo sua posição cômoda por mais um tempo.

"Um filho do rei, que andava caçando, encontrou o carro e abriu o caixão, e vendo a moça, ficou tão namorado que, em lugar de a enterrar, a levou para o palácio e a guardou no seu quarto com toda a riqueza que encontrou.

E a moça sempre a dormir e o príncipe quase doido de paixão.(...)" (ROMERO, S. 2002: 215)

A moça, assim que encontrada, ainda não consegue se disponibilizar totalmente ao relacionamento com o príncipe, ela entra na vida dele, na sua intimidade; porém não o deixa fazer o mesmo. Ela é levada por ele ao seu palácio, ao seu quarto, mas continua em seu sono profundo, relacionando com o príncipe apenas superficialmente, pois ele apenas está enamorado por sua beleza. A moça utiliza apenas elementos externos seus para relacionar-se, ela ainda não consegue um envolver-se com seus elementos internos, com sua identidade ou personalidade.

Ela não conquista o príncipe com suas qualidades internas, porque ainda não sabe o que fazer, como agir e se colocar diante o outro, o que ela precisa dividir com o outro para estar envolvida em um relacionamento afetivo, porém esse momento não 
pode ser postergado a vida toda, caso a pessoa procure edificar por vez sua identidade e sentir-se realizado.

"Só nos tornamos um ser humano completo, realizado em todas as potencialidades, quando, além de sermos nós mesmos, somos capazes ao mesmo tempo de sermos nós mesmos com outros e nos sentimos felizes com isso." (BETTELHEIM, B. 2003: 319)

Nessa estória, como o casamento não ocorre logo após o encontro do príncipe com a protagonista, apesar por toda paixão despertada nele, há então um período de suspensão, onde se entende que haverá uma reformulação da personagem, pois todas personagens que passam por um período de sono profundo ou morte reversível, acordam ou retornam diferentes, conquistando algo ou mudando de posição social.

Assim, havia chegado o momento da moça ser ela mesma com um parceiro, mas para tanto ela precisou da ajuda de uma semelhante, de outra moça, apesar de possuir ferramentas suficientes para envolver-se, a moça não sabia usá-las adequadamente, haveria de ver e aprender com outra que já havia passado por essa experiência, ou talvez, precisasse apenas de um incentivo para dar seu próximos passo. Assim, entra na narrativa a princesa, irmã do futuro marido da moça, e descobre o segredo para o desencantamento.

"Chegou, abriu o caixão e viu a moça e achou tão bonita e estranhou que ela estivesse com uns sapatinhos tão feios de couro. Puxou os sapatos e a moça suspirou e sentou-se pedindo água." (ROMERO, S. 2002: 215)

A moça precisaria se libertar de alguns conceitos, de modelos do passado que não serviriam mais para ela construir sua vida, cada um constrói sua individualidade, sua personalidade por si só, e não com introjeção valores alheios, e fingir sê-los seus. Assim, os sapatos dados a ela podem ser interpretados como os valores alheios que podem ou não fazerem parte de sua identidade ou personalidade, porém esses mesmos valores deram-lhe a oportunidade de refletir e internalizar de seus próprios valores e convicções, momento simbolizado no sono profundo. Assim, os sapatos precisam ser dispensados para que a moça conclua seu processo de amadurecer e estruturar quais serão seus valores norteadores.

"Todas as estórias que consideramos até aqui transmitem a idéia de que se desejamos conseguir a egoicidade, atingir a integridade, e assegurar nossa identidade, devemos passar por processos difíceis; sofrer provações, encontrar perigos, conseguir 
vitórias. Só desta forma podemos dominar nosso destino e conquistar nosso reinado." (BETTELHEIM, B. 2003: 318)

Desta forma, sabe-se então como toda heroína, a moça da narrativa passará por suas provas para legitimar sua auteridade, se em Branca de Neve a protagonista vence todos seus obstáculos logo ao se casar, aqui a personagem central precisa ainda cumprir provações mais árduas após o matrimônio, porque dentro de cada provação, de cada tarefa realizada, com ajuda ou não de entes mágicos, as personagens boas dos contos de fadas aprendem e conquistam algo, enquanto que as personagens más, além de nada aprenderem, são castigadas. Como nossa protagonista é boa, evidentemente ela passará por suas provas, aprenderá e será recompensada.

Suas maiores provas acontecerão após o matrimônio, ritual esse de maior importância para uma mulher, pois ele é marco da vida adulta feminina. Esse ritual é um grande marco na vida das mulheres, pois ele representa a passagem do indivíduo frágil e imaturo, que necessita de cuidados e orientações, ao que já possui experiências e amadurecimento suficiente para ser auto-suficiente e ainda ser responsável por outrem. É a passagem pela qual a moça deixa de ser a filha ou irmã e torna-se a esposa e mãe, implicando-lhe novos direitos, responsabilidades e trocas emocionais.

"Ele (o casamento) é essencialmente um rito de iniciação feminina, no qual um pode sentir-se tudo, menos um herói vencedor. Não é de se espantar que se encontrem nas sociedades tribais certos rituais compensatórios ("antifobias"), como o rapto da noiva, que permitem que o homem, no exaro momento em que deve submeter-se à mulher e assumir as responsabilidades do casamento, se agarre ao que lhe resta do papel de herói." (HENDERSON, J.L. 2008: 176)

O casamento é o desfecho recompensador para a maioria das mocinhas protagonistas dos contos de fadas, já que ele representa uma grande conquista feminina, o amadurecimento e a independência afetiva tanto materna quanto paterna; porém nesse conto, o matrimônio leva a personagem a mais testes, afinal o indivíduo não está estabilizado emocionalmente ou totalmente maduro e seguro apenas porque se casou. Há ainda valores a serem aprendidos e convicções a serem reafirmadas.

Assim, a primeira prova após o matrimônio da moça, será logo em que os gêmeos nascem. Nesse momento, ressurge a feiticeira como a parteira. Mais uma vez não há rejeição ou estranhamento pela presença dessa pessoa; assim, a feiticeira conduz o parto e troca os filhos da moça por animais. Por que a feiticeira volta? Qual a razão dela ainda perseguir a moça? 
Entendendo que a feiticeira é a mãe da moça, só que já em idade um pouco mais avançada, na qual não há mais comparações, em que a mulher mais velha atingiu um patamar de segurança e respeito, no qual ela não é mais avaliada ou comparada a partir de um referencial feminino mais jovem e vigorosa; a mulher mais velha já sabe quem é e qual seu papel na vida. Portanto, a mulher mais experiente a mãe volta a ter com a filha no intuito de mais uma vez cumprir seu papel: impulsionar a jovem e inexperiente mulher a uma nova etapa de amadurecimento na vida feminina.

O parto dos gêmeos ocorre exatamente noves meses após o matrimônio, ou seja, as crianças simbolizam um novo rumo à autonomia, individualização e amadurecimento da moça. É o desligamento com suas origens para criar novos laços e elos com indivíduos alheios ao seu núcleo familiar antigo, a moça começa construir sua identidade relacionando-se de forma diversa às anteriores em sua vida.

"A fenomenologia do nascimento da 'criança' sempre remete de novo a um estado psicológico originário do não-conhecer, da escuridão ou crepúsculo, da indiferenciação entre sujeito e objeto, da identificação inconsciente de homem e mundo." (JUNG. C. G. 2006: 172)

O parto é o momento em que a moça começa a tornar-se consciente da sua nova fase de amadurecimento, porém mais uma vez ela não consegue atravessar essa fase sozinha, a mãe tem de intervir para ela adquirir suas novas experiências. A forma em que a feiticeira intervêm pode parecer cruel, mas o crescimento e amadurecimento não é tarefa fácil ou tranqüila para qualquer indivíduo.

A feiticeira arranca-lhe os filhos e os substitui por um sapo e uma rã, causando-lhe outra expulsão do lar. Apesar dos esforços da moça em tornar-se uma mulher madura, ela ainda não consegue exercer seus papéis femininos adultos sozinha ou satisfatoriamente, por isso, ela ainda passa por privações e provas para compreender o mundo adulto e firmar-se como mulher.

"No fim dos noves meses ela deu à luz a dois meninos, a coisa mais linda que dar-se podia. Mas veio servir de parteira justamente a feiticeira que tinha-lhe dado os sapatos, e, em lugar dos dois meninos, apresentou um sapo e uma jia. O príncipe andava ausente numas guerras e o pai lhe mandou dar parte do acontecido. O príncipe mandou dizer ao pai que matasse a mulher; mas o rei teve pena e somente lhe cortou um dos peitos e a expulsou de casa." (ROMERO, S. 2005: 216)

A ordem de morte feita pelo príncipe é uma alusão àquelas que acreditam que possam evitar o crescimento, que não precisam tornar-se independentes 
emocionalmente, buscar e construir sua identidade, assumir seus valores e abandonar a infância; o assassinato da moça significaria a inadequação de uma mulher imatura em meio a adultos já estabelecidos internamente. Se a moça quer viver como mulher do mais espaço para imaturidade.

Porém, a moça é poupada pelo rei, ou seja, a única figura paterna da narrativa, figura essa em que a filha deseja ser compreendida, protegida e auxiliada quando todos morta, porém a expulsa de casa depois de corta-lhe um seio, afinal o amadurecimento é um aprendizado muitas vezes solitário.

O seio cortado significa o lado da feminilidade que a moça ainda não sabe ou não consegue lidar. O homem mais velho enxerga isso e por isso lhe dá mais uma chance de buscar a si mesma, de aprender a ser mulher, assim enquanto ela não é uma mulher completa, ela perde um dos aspectos que mais destacam e diferiam as mulheres dos homens - o seio.

"O seio é sobretudo símbolo de maternidade, de suavidade, de segurança, de recursos. Ligado à fecundidade e ao leite - o primeiro alimento -, é associado às imagens de intimidade, de oferenda, de dádiva e de refúgio." (CHEVALIER, J. 2008: 809)

A protagonista da narrativa, mesmo alcançado o matrimônio, estabelecendo laços emocionais com outro indivíduo, ela ainda não se sente segura como mulher. $\mathrm{Na}$ primeira dificuldade da vida conjugal, o nascimento dos filhos, ela demonstra não ser ainda auto-suficiente e permite que a feiticeira tome a frente nesse momento, que seria único e somente dela. Por isso, ela tem que merecer ser uma mulher, enfrentar outras provações e fortalecer-se nelas e ser uma mulher que conduz sua própria vida.

Assim, mais uma vez, a protagonista é afastada do lar e inicia outra jornada de auto-conhecimento. Dessa vez, a primeira coisa que encontra não é refúgio ou pessoas boas que lhe ajudem, mas uma fonte de água, que além de matar sua sede, devolve-lhe o seio:

"A moça saiu pelo mundo afora; tendo muita sede chegou a uma fonte e bebeu água; passou água no peito e o peito tornou a crescer." (ROMERO, S. 2005: 216)

A jovem tem seu seio reconstituído, símbolo de feminilidade, assim que ela ganha o mundo, em que sente sede. A sede pode ser interpretada por um forte impulso ou necessidade de se atingir algo, ou seja, ela quer se realizar como indivíduo adulto, 
aprender a ser uma mulher; desta forma, desejando isso ela encontra a fonte que lhe dará o necessário para atingir seu objetivo.

A água possui diversas significações simbólicas em várias culturas, mas há alguns pontos temáticos em comum entre todas elas, em que a sua representatividade signifique: fonte de vida, meio de purificação e centro de regeneração. A moça tem saciada, então, não uma necessidade biológica, mas o preenchimento de uma lacuna interior. A jovem ao matar sua sede e banhar-se na água indica uma purificação de sua vida, abandonando certas atitudes e regenerando-se ao caminho correto de uma mulher. Ainda, no dicionário de símbolos de Chevalier, esse elemento é descrito como: "A água é o símbolo das energias inconscientes, das virtudes informes da alma, das motivações secretas e desconhecidas." A água representa algum valor buscado pelo indivíduo para formação de sua índole, mesmo que ele não faça de maneira consciente ou obstinada.

Então, a moça após ter consciência de alguns elementos que comporiam sua identidade feminina, ela está pronta a seguir sua viagem e interagir com seus filhos, ela já está pronta para desempenhar seu papel de mãe:

"Aí, ela seguiu viagem e foi ter à casa de um gigante e tomou um racho lá com os seus dois filhos, porque os filhos a feiticeira lhe entregou." (ROMERO, S. 2005: 216).

Os dois filhos, que não apareceram no momento da expulsão do lar, surgem juntamente da moça logo após o banho regenerador dela na fonte de água, sinalizando ser esse um banho ritual, purificador o qual a deixa apta para sua nova função. É o momento da conscientização da maternidade e compreensão das grandes mudanças em sua vida, pois ela deverá deixar o papel de filha protegida e auxiliada pelos mais velhos e experientes para cuidar de indivíduos dependentes e frágeis.

Porém, mesmo realizando-se como mãe, ainda há um plano emocional e afetivo na vida de uma mulher a ser realizado: ser companheira. A capacidade de envolver-se com outro adulto e manter um relacionamento de igualdade e companheirismo com ele. Ao indivíduo adulto não basta ser seguro de si, conhecer sua personalidade e identidade e ter realizações pessoais não são suficientes para alcançar a felicidade, faz-se necessário também o outro; alguém que se possa confiar e dividir tanto alegrias quanto aflições. 
"Mas, embora este auto-desenvolvimento seja meritório, e possa salvar nossa alma, ainda não basta para sermos felizes. Para isso, devemos ultrapassar o isolamento e formar um elo com o outro. Mesmo que vivamos num plano de vida muito elevado, o EU sem o TU vive uma existência solitária." (BETTELHEIM, B. 2003: 318)

Por isso, quando a moça segue seu caminho, após deixar a fonte, acaba encontrando abrigo na casa de um gigante. Ele não é descrito por nenhuma característica física ou psicológica, ele não é definido como bom ou mau, é apenas um gigante que dá abrigo a moça e seus filhos. O gigante é a representação do marido, ou melhor, da falta de intimidade entre o casal; a moça já achou seu lugar como mãe, mas ainda não sabe se colocar como esposa e companheira do príncipe. Dessa forma, ela sente-se na presença de um gigante, como diminuída e inferiorizada.

"O mito dos gigantes é um apelo ao heroísmo humano. O gigante representa tudo aquilo que o homem tem de vencer para libertar e expandir sua personalidade." (CHEVALIER, J. 2008: 470).

A moça precisa aprender a como se relacionar com seu marido, principalmente após o nascimento dos filhos, pois a dinâmica de um casal muda muito, a mulher pode ficar quase que totalmente absorvida com os cuidados e rotina dos filhos, esquecendo-se do marido ou o deixando a certa distância dos acontecimentos.

O marido parece um estranho a ela, para a mulher são muitas coisas a absorver após o matrimônio, há mudanças grandes e adaptações a serem feitas. Assim, existirão momentos em que a mulher não se sentirá tão feminina ou segura de si, não saberá como agir com seus filhos ou marido, se sentirá exilada no próprio lar ou então ameaçada sem motivo aparente pelo próprio companheiro. Porém, são todos obstáculos a serem vencidos para a fortificação e reafirmação da personalidade feminina.

"(...) andando o príncipe em caçadas, passou pela casa do gigante e viu os dois meninos e tomou por eles muita afeição. Noutros dias, passava pela casa do gigante, até que um dia viu a sua mulher. Muito se arrependeu do que tinha feito e tornou a viver com ela, mandando matar a feiticeira." (ROMERO, S. 2005: 216)

O trabalho de intimidade não é feito apenas por uma das pessoas do casal, há vontade e esforço de ambos, para que seja construído um elo sentimental significativo. Por isso, mesmo dividindo a mesma morada e rotina, isso não implica que o casal construa laços íntimos, é preciso que haja entrega de um ao outro, que haja 
compreensão, companheirismo, carinho, ou seja, as trocas saudáveis e benéficas entre adultos maduros.

Se a moça não soube lidar com as mudanças em sua vida trazidas pelo matrimônio, o rapaz também não se mostrou muito hábil em auxiliar sua companheira nesse momento. Ela entende que precisa amadurecer e a lidar com esse processo sozinha, e ela o faz. Mas após isso, ela não é acolhida pelo homem com quem se casou, mas por um gigante; indicando que o casal precisa superar mais um obstáculo para serem felizes e realizados.

Agora que a moça já passou pelo seu processo de amadurecimento, cabe ao rapaz enxergar isso e começar a relacionar-se com ela de outra forma, pois agora ela é uma mulher pronta para todas as implicações do relacionamento afetivo entre adultos maduros.

"A mensagem destas estórias é que devemos abandonar nossas atitudes infantis e adquirir outras maduras se desejamos estabelecer o elo íntimo com o outro, o que promete felicidade permanente para ambos." (BETTELHEIM, B. 2005: 319)

Assim, após a moça abandonar suas atitudes infantis, chega o momento do príncipe deixar seus últimos traços imaturos para trás. Dessa forma, há primeiramente uma aproximação do homem com os filhos, a qual ele toma consciência de ser pai, para só então, reaproximar-se da esposa, entendendo quais as mudanças ocorridas em suas vidas.

Quando o casal se enxerga, há a entrega mútua em que eles comprometem-se um ao outro, deixando para trás seus passados, representado na morte da feiticeira. Eles eliminam a última forma de imaturidade e insegurança de suas vidas e vão de encontro à sua felicidade conjugal e pessoal.

\section{3) "Rapunzel" compilada pelos irmãos Grimm.}

Rapunzel narra a estória de uma menina que era fruto do maior desejo de um casal, mas realizado após muitos anos de casamento. A esposa tem suas preces ouvidas por Deus e é presenteada com a gravidez. E com isso vêm os desejos de saborear certas 
comidas da futura mãe, que vê de sua janela o jardim da vizinha - a bruxa - o belo canteiro de rapúncios, os quais a afligem tanto seu apetite, que fazem o marido buscálos, apesar dos perigos.

Primeiramente, o marido conseguiu com sucesso levar a esposa os rapúncios, porém na sua segunda tentativa foi flagrado pela bruxa que o permitiu que levasse quanto fosse necessário e quantas vezes quisesse os rapúncios, para que sua mulher não morresse de vontade, porém em troca o casal deveria dar a bruxa o bebê que nasceria. Apavorado, o homem concordou.

Assim que a mulher dá a luz a uma menina, a bruxa apareceu e deu-lhe o nome de Rapunzel e a levou consigo. Logo a menina se tornou a criança mais bela da face da Terra, e aos treze anos foi trancada pela bruxa em uma torre bem alta no meio da floresta, a qual tinha apenas uma janelinha. Quando a bruxa queria visitar Rapunzel, ela ficava embaixo da janela e cantava para a menina jogar suas tranças, pelas quais ela subia e entrava na torre.

Dois anos depois aconteceu de um príncipe entrar na floresta e ouvir o belíssimo canto de Rapunzel, fazendo com ele se apaixonasse e procurasse uma maneira de entrar na torre e conhecer a dona de tão bela voz. Evidente que o príncipe não achou nenhuma entrada e voltou para casa desiludido, porém não desistiu e voltou à floresta, e desta vez pode observar a bruxa que entrava na torre pelos cabelos de Rapunzel.

O príncipe, então, usou do mesmo método com Rapunzel, conseguiu enganar a moça, cantando a mesma canção que a bruxa cantava e logo ele recebeu do alto da torre as tranças da moça. Assim os dois conheceram-se e passaram muitos dias encontrandose até serem descobertos pela bruxa, que se sentiu traída e com ódio castigou ambos.

Rapunzel teve suas tranças cortadas e foi expulsa para um deserto, enquanto ao príncipe, a bruxa enganou-o colocando as tranças cortadas na janela, e quando ele subiu e encontrou-a lá gritando e dizendo que Rapunzel estava perdida para ele, o príncipe desesperou-se e pulou pela janela da torre e acabou caindo em cima de espinhos que lhe furaram os olhos, deixando-o cego.

Ambos passaram anos perambulando, longe um do outro, até que por fim o príncipe cego chega ao deserto em que Rapunzel vive com seu casal de gêmeos. Ele ouviu a bela voz dela e foi ao seu encontro, ao vê-lo Rapunzel chora e deixar cair duas lágrimas nos olhos do príncipe que fica livre da maldição da bruxa e volta a enxergar. Então, a família é levada pelo príncipe para seu reino e lá viveram felizes por muitos e muitos anos. 
Em Rapunzel o que deflagra a narrativa é o maior desejo de um casal: ter um filho. São anos de orações e espera até alcançar o sonho tão almejado; engravidar. Mas esse desejo não é tão simples ou fácil de ser concretizado, afinal transformar-se em pais não acontece simplesmente com o surgimento de uma criança; ser pai ou mãe exige diversas mudanças, adaptações, amadurecimentos e responsabilidades que não chegam juntos com a criança.

"(...) que ela, que gostava muito daquela verdura, sentiu muita vontade de comê-la. Essa vontade foi aumentando de dia para dia, e, como sabia que seu desejo não podia ser satisfeito, ela começou a emagrecer e empalidecer, até que seu estado de fraqueza alarmou o marido, que lhe perguntou:

_O que está afligindo, minha querida?

_Ah! _ ela replicou. _ Se eu não comer um pouco do rapúncio que se vê daqui no quintal da bruxa, eu vou morrer.” (GRIMM, J. \& W. 2000: 322)

A realização desse desejo para o homem define-se assim que ele sabe da gravidez de sua companheira, pois seu papel está cumprido. Ele já se torna pai a partir do momento em que há um bebê; enquanto que para mulher, o desejo de ser mãe não é satisfeito logo após ter conhecimento da gravidez, ao contrário, surgirão outros desejos, aqueles capazes de remeter ao papel de ser mãe: a de ser a primeira referência na vida do filho, e por um bom tempo, a única. Dessa maneira, a personagem masculina, o pai, deixa rapidamente a estória.

Surge, então, o desejo incontrolável da mãe por rapúncios do jardim vizinho, em que o marido se vê obrigado a furtá-los, pois ao contrário a esposa definharia até a morte e juntamente o bebê. Esse desejo imperativo e inflexível fará da pequena menina a filha adotiva de uma bruxa. Os pais biológicos deixam a narrativa e o surge a bruxamãe.

Essa bruxa não demonstra nenhuma malvadeza ou feitiços, ela apenas exige a entrega do bebê que irá nascer a ela. O pai concorda com a exigência de entregar à criança, indicando como ele é desnecessário para atender as próximas exigências para a concretização da maternidade. O que virá a seguir é o desejo da mãe de se ligar tão intimamente com sua cria, que a figura masculina torna-se um empecilho para a relação que a mãe deseja ter.

"A feiticeira, então, dominou a raiva e disse ao homem:

_ Se é assim como dizes, vou permitir que leves tantos rapúncios quanto quiseres, mas com uma condição: terás de me dar a filha que tua mulher vai dar à luz. Ela será muito bem tratada, e cuidarei dela como se fosse minha filha." (GRIMM, J. \& W. 2000: 323) 
Mãe e bruxa são personagens homólogas, pois ambas querem a mesma coisa: somente a criança para si mesmas. Ambas não estão dispostas a negociar ou compartilhar essa vontade. A figura da mãe sai para dar lugar à da bruxa, que personifica melhor a mulher egoísta e má, que pode expulsar o pai da vida da filha e ainda a sufocar, aprisionando-a em uma torre e sendo a única pessoa a conviver com a moça.

"Em geral, somente um aspecto do conteúdo inconsciente pode ser aprendido de cada vez, passando os outros aspectos a ser rejeitados. A sombra do herói é, pois, aquele aspecto do arquétipo que foi rejeitado pela consciência coletiva." (VON FRANZ, M. L. 2005: 134)

A figura materna, que geralmente habita as narrativas como uma heroína, uma personagem bondosa, deixa a cena para dar lugar a sua sombra, para aquela que reúne os vícios que mesmo sendo rejeitados, continuam existindo e fazendo parte da índole humana. Entretanto, para uma criança a ambivalência de características em um ser humano é muito difícil para ser entendido, para os mais jovens e inexperientes o mundo é classificado de forma maniqueísta: bom ou mau.

A personagem da bruxa no decorrer da narrativa mostra-se má e perversa, quando se sente contrariada, traída ou invadida; quando Rapunzel não lhe dá mais total atenção. Aparentemente, a bruxa não traria nenhum problema a ninguém, desde que suas vontades estivessem sendo feitas, ou seja, suas maldades não seriam gratuitas, teriam uma causa. A imagem da bruxa não pode ser relacionada com a de uma ótima mãe, dando todo seu carinho e amor à filha, trazendo muita empatia ao pequeno leitor ou ouvinte.

"Cada figura é essencialmente unidimensional, capacitando a criança a compreender suas ações e reações facilmente. Através de imagens simples e diretas a estória de fadas ajuda a criança a ordenar seus sentimentos complexos e ambivalentes, de modo que estes comecem a caber cada um num lugar separado, em vez de ser tudo uma grande mistura." (BETTELHEIM, B. 2003: 92)

Assim quando a bruxa assume o relacionamento com a criança, ela começa por em prática seu desejo - ser a única fonte de amor e satisfação da filha. A bruxa guarda os traços negativos da índole humana, ela representa os defeitos e más ações que as pessoas possuem ou realizam, porém não admitem ou assumem. A bruxa representa 
aspectos que as pessoas repudiam em uma mãe, mas que as mulheres não conseguem deixar de sê-lo uma vez ou outra na vida.

Rapunzel cresce aos cuidados dessa figura feminina e quando a menina atinge a puberdade, há outra grande intervenção da bruxa na vida delas. Agora, não é mais a figura paterna que pode atrapalhar a dinâmica desejada pela mulher mais velha, mas todas as outras pessoas que possam a vir se interessar por Rapunzel; assim a moça é encerrada em uma altíssima torre no meio de uma floresta.

A puberdade é uma fase repleta de transformações para todas as pessoas, tanto biológicas quanto psicológicas, é o momento que começa a se esboçar o adulto, o indivíduo maduro que surgirá de uma criança frágil e dependente. É a fase em que os indivíduos começam a expandir seus horizontes, relacionarem com diversas pessoas e interessarem-se por vários assuntos, em que o indivíduo em formação testa as possibilidades da vida, para depois definir-se na sua fase adulta.

"Rapunzel tornou-se a criança mais linda que havia sobre a face da Terra. Que quando tinha doze anos, a bruxa trancou-a em uma torre no meio da floresta e que não tinha escadas nem portas, mas tinha uma janelinha bem no alto. Quando a feiticeira queria entrar na torre, colocava-se diante da janela e cantava:

Rapunzel, Rapunzel!

Desce os seus cabelos." (GRIMM, J. \& W. 2000: 323)

A bruxa percebe que não será mais suficiente na vida dessa jovem, que ela precisa intervir energicamente, por isso resolve manter onde a menina na torre isolada de todo o mundo, recebendo apenas a sua visita. A menina é totalmente dominada pela mulher mais velha, o único ponto de referência em sua vida é ela.

A mulher mais velha tem a ilusão de nutrir todas as necessidades da moça, pois é ela que circula fora da torre e lá sobe para relacionar-se com a mesma, mantendo seu posto de ser o único indivíduo a ser amado, ela é a única visão do mundo que a moça possui, a mulher cerceia tanto a mais jovem, que ela realmente chega ser a única fonte de valores, a qual Rapunzel aceita e submete-se por carência e falta de opções.

"O processo do conto vai num crescente isolamento da filha com a mãe até a separação radical, deixando bem claro que fora da torre uterina só há um deserto. Essa mãe, além de querer a filha totalmente para si, quer crer que é tudo para ela." (CORSO, D. \& M. 2006: 65) 
Rapunzel nunca pode deixar a torre, e ela sempre obedece à voz da bruxa e a ajuda entrar em seu cárcere com suas tranças. O relacionamento delas é ainda simbiótico, como é do bebê com sua progenitora, que ainda não consegue distinguir-se dela, já que nessa primeira fase de vida a mãe é realmente sua única fonte de alimento, cuidado e satisfação; a mãe está sempre presente para o bebê, assim que ele faz menção de qualquer necessidade. Entretanto, a relação simbiótica aqui se inverte: a mãe necessita da filha,

Os cabelos de Rapunzel, os quais dão livre acesso à torre, ou seja, a vida ou mundo da moça, tais extensões corporais representam o cordão umbilical que ainda na puberdade não foi cortado, mantendo uma ligação tão grande entre ambas que há uma ligação realmente física. O relacionamento foi construído de forma que as envolvidas não têm a consciência e distinção de onde começa o espaço físico de uma ou da outra. A simbiose continua.

Entretanto, chega o momento de mudar - a puberdade. Chega, então, o desejo da menina, da moça em ser outra, ou melhor, ser única: encontrar-se no meio da simbiose materna e entender o que sou EU e que é o OUTRO, para assim revelar-se ao mundo, descobrir sua personalidade e identidade, revelar-se um indivíduo diferente de sua mãe.

Assim, percebe-se que esse relacionamento possessivo não pode ser mantido apenas pelo desejo de um dos indivíduos, se um pretende ser tudo na vida do outro, o outro precisa estar disponível para receber tudo que o primeiro tem a oferecer. Por muito tempo, Rapunzel aceitou o relacionamento possessivo da bruxa, tanto que só tinha olhos e ouvidos para ela, porém um dia essa situação mudou, o relacionamento começou a não ser satisfatório para a moça.

"Um ou dois anos depois, aconteceu que o filho do Rei entrou na floresta e passou pela torre. Ouviu, então, um canto, tão belo, que ele parou para ouvir. Era Rapunzel, que, em sua triste solidão, cantava para os males espantar." (GRIMM, J. \& W. 2000: 323)

É o início da libertação de Rapunzel, quando a moça esboça seus primeiros sinais de insatisfações e de querer buscar algo além das paredes da torre que a aprisionara. Seu canto não é apenas uma distração, mas uma forma de atirar-se ao mundo, de sair de algum modo daquela prisão, atingir outros limites e tentar conhecer novas referências. 
E isso realmente ocorre, o canto de Rapunzel sensibiliza o príncipe de tal forma, que não consegue parar de pensar naquele belo canto e tenta conhecer a dona da voz. Quando surgem os primeiros traços de descontentamento da moça de infelicidade do relacionamento sufocante, é o momento em que ela não está mais totalmente disponível para a bruxa, é quando ela deseja algo mais para si mesma, algo de sua própria escolha.

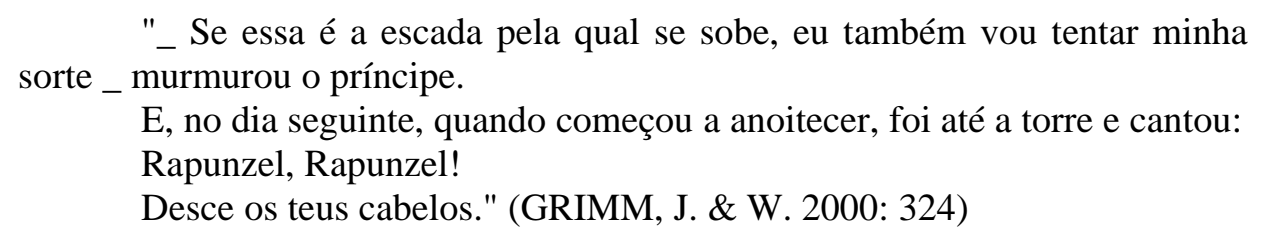

Mas se Rapunzel só atende e conhece a bruxa, como ela ao ouvir a voz de um homem, dá-lhe as tranças? Ela agora está disponível para uma nova relação, ela é capaz e quer ouvir o príncipe e atendê-lo. Ela não é enganada por disfarces ou truques, o príncipe faz o mesmo que a bruxa e obtém a mesma resposta. Rapunzel está acostumada a fazer o que a bruxa lhe pede e quando ouve a música em outra voz, ela não hesita e continua obedecendo, mas será que o relacionamento com o príncipe o mesmo que o com a bruxa? Ela quer ser a pessoa possuída por esse novo indivíduo que chega em sua vida? O que ele deseja dela?

O primeiro sentimento despertado em Rapunzel é o medo, agora está frente a frente com um homem que nunca havia visto, e quando este lhe diz docemente que ela havia tocado seu coração com sua bela voz, Rapunzel perde o receio e se entrega a esse novo relacionamento.

"Rapunzel perdeu o medo, e, quando o príncipe lhe perguntou se o aceitaria como marido, viu que ele era moço e bonito, pensou que ele a amaria mais do que a velha Senhora Gothel, e disse que sim, deixando que ele lhe tomasse as mãos entre as deles." (GRIMM, J. \& W. 2000: 324)

Ela deseja criar outros laços, comunicar-se, sentir-se parte do mundo e de outras pessoas. Seu desejo então a liberta da tirania materna, ela abre espaço para o outro em sua vida, para o sexo oposto, para outras formas de realização e satisfação, além daquelas dadas pela mãe.

O príncipe é a oportunidade de viver conforme suas regras também e não apenas com aquelas impostas pelo outro, ou seja, a moça poderá construir com o príncipe um relacionamento no qual ela também possa expressar seus desejos e ser aceita por sua personalidade com determinadas qualidades e defeitos. A moça dá início à sua vida 
adulta, permite-se envolver com um homem e vivenciar todas as implicações que essa nova fase da vida apresenta.

As tranças eram até então a extensão corporal que ligavam Rapunzel e a feiticeira, mas agora elas também ligavam a moça a uma nova pessoa, a um homem, o príncipe. Se com a bruxa esse elo foi construído de forma tirânica e opressiva, indicando quanto uma mãe pode ser possessiva e a filha um ser sem vontades próprias; com o príncipe esse elo é diferente, ele é compartilhado por livre e espontânea vontade.

Entretanto, o desligamento com o seio materno não é um processo rápido, fácil ou descomplicado, a filha tem a necessidade de sentir-se segura e capaz para passar por isso, e quanto à mãe, ela precisaria ser compreensiva e facilitar essa transição para a jovem. Mas, na narrativa acontece exatamente o oposto, há uma mãe possessiva e uma filha dominada e insegura.

"_ Eu te acompanharei de boa vontade, mas não sei como sair daqui disse (Rapunzel)._ Todas as vezes que subires aqui, traze contigo uma meada de seda, e vou tecer com elas uma escada, e, quando ela ficar pronta, eu descerei e partirei contigo em teu cavalo." (GRIMM, J. \& W. 2000: 324)

Assim, Rapunzel não conta para a bruxa o está acontecendo em sua vida, e mantém-se dividida nos dois mundos: o restrito e extremamente controlado, da torre e da bruxa; o de novas experiências e adulto, em que ela possui um valor e posição, o mundo trazido com príncipe. Ela recebe tanto as visitas da bruxa e quanto as do príncipe, não tomando nenhuma atitude prática para concretizar sua transição da vida infantil à adulta.

A heroína não é madura o suficiente para cortar todos os laços com sua antiga vida, por isso ela precisa e pede ajuda ao príncipe, aquele que entra em sua vida para dar a motivação necessária a Rapunzel tornar-se adulta. Ela pede ao príncipe que traga fios de seda para dentro da torre, assim teceriam uma escada e escapar de lá juntos.

As tranças que unem tanto Rapunzel com a bruxa como ao príncipe também, não poderiam mais continuar sendo a única forma de elo emocional na vida dessa moça, pois se assim for, todas suas relações se construirão da mesma maneira: Rapunzel sendo oprimida por outro indivíduo ciumento e possessivo.

Até conhecer o príncipe, Rapunzel acreditava e conhecia apenas um tipo de construção emocional, àquela em que ela era sufocada, por isso, no início ela também usa suas tranças com o príncipe; mas quando percebe que pode e quer relacionar-se de outra forma, sabe que é necessário construir outro tipo de laço, basear a relação de outra 
forma. Assim ela tem a idéia de construir uma escada de fios de sedas, em que o príncipe também ajudaria a fazer.

"A história de Rapunzel é profundamente ligada a essa trama do filho como possessão materna. Mas longe do conto de fadas, nenhum filhote humano faz bem esse papel, todos mostram pouca vocação para esse idílio - se não for assim, pagará o preço da desconexão, da psicose, por essa entrega. Talvez por isso essa história se conservou e tão bem-vinda, ela mostra que há uma saída mesmo quando se tem a mais possessiva e dedicada das mães." (CORSO, D. \& M. 2006: 66)

Rapunzel compreende, então, que não poderiam caber em um mesmo lugar dois relacionamentos tão distintos. Assim, não basta apenas construir um caminho diferente para se encontrar com o príncipe, é necessário fugir da torre, distanciar-se da bruxa, ser independente. Porém, esse rompimento deve acontecer entre as duas mulheres, a mãe e filha; por isso Rapunzel deixa escapar que a bruxa pesa muito mais que o príncipe ao subir pelas suas tranças.

"_ Por que será, senhora Gothel, que é tão mais difícil para mim sustentar nos meus cabelos a senhora do que o jovem príncipe? (GRIMM, J. \& W. 2000: 324)

Este é o rompimento do cordão umbilical, filha explicita o peso do sufocamento causado pela relação possessiva e ciumenta que a mãe mantém com ela, há a quebra o ciclo simbiótico. Filha indica à mãe que o amor dado a ela é um peso muito maior ao qual ela pode ou quer agüentar.

Este é o momento de amadurecimento, o início da vida adulta, o qual leva os indivíduos para certas escolhas, decisões sobre quem são e como querem viver. Quando precisam ser tomadas decisões e atitudes para definirem sua própria personalidade.

O lapso de Rapunzel é o ponto final da vida dupla, de se dividir entre a tirania da bruxa e prazer com o príncipe; é que a forma encontrada de se libertar da vida de prisioneira, ela revela seus encontros à bruxa e espera sua vingança, já que é assim que pessoas más agem.

"Furiosa, ela agarrou as belas tranças de Rapunzel, enrolou-as em torno de seu punho direito e, pegando uma tesoura, cortou-as, e foi tão impiedosa que levou Rapunzel para um deserto, onde teve que viver, sofrendo as maiores privações, desesperada." (GRIMM, J. \& W. 2000: 326) 
A mãe substituta fica furiosa com Rapunzel e corta suas tranças, as quais eram a extensão corporal da jovem que permitia a mulher mais unir-se a ela. A destruição desse elo não se dá apenas por retaliação da traição pela filha adotiva, mas também por ser essa a forma que unia o jovem casal. O ódio da bruxa está justamente no fato dela ter construído um determinado elo com Rapunzel para se manter única no relacionamento, mas que agora estava sendo usufruído por outro.

Rapunzel, assim, é banida para o deserto, onde nada existe apenas aridez, onde nada floresce ou cresce. Não há meios-termos para a bruxa, Rapunzel só poderia amá-la e a mais ninguém, e agora que há um terceiro elemento na vida sentimental da moça, ela deve ser punida, ou melhor, banida da vida protegida na torre e sofrer com o distanciamento e solidão.

"A criança tanto deseja como teme que os pais não se sintam dispostos a aceitar seu impulso de independência, e que busquem vingança. Ela assim deseja porque tal demonstraria que o pai não pode deixá-la partir, o que prova a importância da criança." (BETTELHEIM, B. 2003: 125)

Finalmente, há o rompimento entre filha e mãe, porém este não será bem aceito pela mãe, que mantinha e alimentava a relação simbiótica para seu prazer e realização. Quando a moça mostra que cresceu e tornou-se uma mulher, com suas próprias vontades e escolhas, a mãe fica frustrada e furiosa, pois vê agora que não tem mais espaço na vida daquele ser que dependia dela para tudo, em que ela era a única referência e fonte de amor e prazer.

Rapunzel inicia o seu exílio no deserto, e lá dá a luz a um casal de gêmeos, fruto do relacionamento com o príncipe ainda na torre, passando rapidamente de filha para mãe, ou seja, assim que há o rompimento do relacionamento possessivo materno, ela pode tornar-se outra pessoa, ela deixa de ser filha para ser mãe agora, mostrando que mesmo nas piores situações ou em condições difíceis. Mas quando há um posicionamento, opção e atitude do indivíduo, há uma definição da própria identidade levando-o ao amadurecimento.

A vingança e castigo aplicados em Rapunzel são estendidos ao príncipe, pois de certa forma, ele toma o lugar da bruxa. Porém, seu castigo não é o afastamento simplesmente da torre, mas de sua amada. O príncipe defronta-se com a bruxa e é amaldiçoado por ela a ficar cego. 
"_ Vieste encontrar tua querida? Fica sabendo que o belo pássaro não está mais cantando em seu ninho. O gato comeu e vai também furar teus olhos. Rapunzel está perdida para ti. Nunca mais irás vê-la." (GRIMM, J. \& W. 2000: 326)

A bruxa não atira o príncipe pela janela ou lhe joga alguma coisa nos olhos deles, ela apenas o ameaça com palavras e o repreende por ter ousado olhar e desejar aquela que deveria ser apenas dela. A bruxa não pretende destruir o príncipe, pois na verdade ela ama Rapunzel de forma egoísta, e isso é um ato imaturo e tolo, acreditar que alguém pode amar exclusivamente somente outro indivíduo e ser retribuído da mesma forma, mas não um ato de uma vilania.

Então, em razão do desespero e imaturidade do rapaz, ele acaba se autoinfringindo o castigo: joga-se da torre e cai sobre espinhos que o deixam cego. Ele é um jovem que ainda não age como um homem adulto, ele espreita a torre para saber que horas pode subir para ver sua namorada e não revide quando ameaçado pela bruxa, por isso ele também tem que vagar sozinho para passar e tribulações e sair delas como um homem adulto.

Assim, logo após a queda, o príncipe vaga sozinho, lamentando-se da perda de seu amor até chegar ao deserto onde se encontram Rapunzel e seus filhos. Lá há o reencontro dos amantes entre muitas lágrimas, as quais curam a cegueira do príncipe, fazendo-o enxergar pela primeira vez sua família para, então, levá-la ao seu reino e lá viverem felizes.

"Mencionei anteriormente como é consolador para a criança ouvir, de modo simbólico, que ela possui em seu próprio corpo os meios de conseguir o que deseja - assim como o príncipe alcança Rapunzel pelas tranças dela. O final feliz em Rapunzel novamente ocorre através do seu corpo: suas lágrimas curam os olhos do amado, e com isso eles recuperam o reinado." (BETTELHEM, B. 2003: 182)

A narrativa indica um fator constante da vida: a maioria das soluções e respostas para os problemas e angústias cotidianos estão em nós próprios. A felicidade não advém de fatores externos ou nos é entregue por outros, ao contrário ela está em nós mesmos, ou seja, a realização e felicidade pessoal só são atingidas quando soubermos usar nossos próprios recursos intelectuais e sentimentais, caso contrário, estaremos sempre entregues a sorte, dominados pelo ambiente ou outros.

Encontrar-se no deserto é o começo da vida adulta para ambos os jovens, pois essa passagem de tempo representa a assimilação de diversos conteúdos da identidade 
de cada um, foi o período de amadurecimento e de transformação de duas crianças em adultos, homem e mulher.

O choro de Rapunzel representa o sofrimento e as perdas que tiveram pelo caminho para atingirem a maturidade, para abandonarem a torre e a antiga vida que ela representava - a infância - e assim alcançar novas terras, atingir seu crescimento pessoal - a fase adulta.

Ao final da narrativa, as personagens estão prontas, não apenas para ajudarem e socorrerem-se mutuamente, mas também a constituir uma família e construir uma vida boa juntos, um com o outro, como homem e mulher.

\section{4) "A Moça Tecelã" de Marina Colasanti.}

A Moça Tecelã é a narrativa sobre uma jovem que vivia sozinha e tecia sua própria vida, ou seja, o tecer aqui significa viver, produzir. Em seu tear, ela mistura as cores do céu da manhã, tece seus alimentos na hora da fome, tece as paisagens que gostaria de apreciar e segue sua vida assim: tecendo dia após dia tudo que precisa e deseja. Entretanto, conforme ela tecia, houve o momento em que se sentiu sozinha, fazendo- a pensar pela primeira vez como seria bom ter um marido ao seu lado.

Então, com muito capricho ela começou a tecer seu marido. Aos poucos foi aparecendo um rosto barbado com chapéu emplumado, corpo aprumado e sapato engraxado. E logo após o último ponto dado de seu pé, o moço rapidamente entrou em sua vida, fazendo a moça sonhar como seria feliz sua vida ali por diante.

Durante algum tempo, a moça foi feliz, porém o rapaz ao descobrir o poder do tear, pensou somente em tudo o que aquele instrumento poderia lhe dar. Então, começou a fazer pedidos para a moça, que no início achou-os justas, pois ele desejava uma casa maior, já que agora eram dois e precisavam de mais espaço.

A casa foi feita com as belas linhas escolhidas pelo rapaz, que ao vê-la pronta ele não se satisfez, pois percebeu que poderia exigir um palácio, feito com pedras e arremates de prata; e assim o fez. A moça teceu, por vários meses, torres, pátios, salas, tudo ao capricho de seu marido, e quando finalmente o palácio ficou pronto, o marido escolheu para moça e seu tear o quarto da mais alta torre, para que lá ela ficasse escondida e ninguém descobrisse sobre ela e seu tear. 
Lá a moça viveu sem descanso e muito infeliz, realizando os caprichos do marido que nunca estava satisfeito com que ganhava do tear. E tecendo assim, dia após dia sem descanso, ela trouxe o tempo em que sua tristeza era maior que tudo que havia feito. Neste dia então, ela decidiu desmanchar tudo aquilo que a tornara infeliz, levantou-se à noite durante o sono do marido e começou a desmanchar todos os pontos do castelo, das estribeiras, cavalos e tudo mais.

A moça pode ter de volta sua pequena e seu jardim, as coisas que havia tecido quando só existia ela. Ao acabar da noite, o marido acordou e estranhou tudo a sua volta, porém não teve nem de levantar-se da cama, pois a moça tecelã puxou rapidamente os fios que o formavam e o desfez. Então, ela voltou a escolher uma linha clara e começou a tecer o delicado traço de luz da nova manhã em sua vida.

"Moça Tecelã" é uma narrativa que pode ser considerada um conto de fada contemporâneo, pois mesmo não havendo fadas, madrasta ou floresta, há a magia do tecer o imaginado e torná-lo real, há um príncipe, e o mais importante: há uma heroína testada e sofrida, que ao final alcança sua redenção e recompensa.

Essa narrativa, apesar de ter muitos anos de separação das outras analisadas nessa dissertação, não possui uma grande diferenciação em sua temática em relação às narrativas anteriores, pois ela também trata da formação da identidade e personalidade da mulher, ela apresenta, ou melhor, representa as angústias e desejos femininos. Entretanto, a estória contada por Marina Colasanti mostra uma jovem mulher que procura sua felicidade em meio a um mundo em construção, com novos valores e conceitos.

A Moça Tecelã difere-se de nossas heroínas justamente por haver uma dificuldade diferente na sua busca, pois se por muitos anos as jovens e as mulheres depararam-se com os mesmos problemas, angústias e desejos, nessa narrativa há o mesmo confronto, porém em outras condições.

As condições vividas por essa heroína são outras, pois as anteriores aventuravam-se em um mundo com uma ordem social muito bem estabelecida e aceita, enquanto a Moça vive em um mundo em que ela participa da construção, em que suas ações modificam efetivamente as coisas em sua volta. Nessa narrativa, a protagonista tem o poder de tomar suas próprias decisões e modificar aquilo que não lhe agrada. 
breve, na penumbra trazida pelas nuvens, escolhia um fio de prata, que em pontos longos rebordava sobre o tecido. Leve, a chuva vinha cumprimentá-la à janela." (COLASANTI, M. 2008)

Porém, para mudar algo é necessário saber o que se precisa, ou melhor, o que se deseja. Os indivíduos nunca buscam somente aquilo que precisam, mas principalmente o que desejam; pois necessitando ou não de algo, o que move o ser humano, o que lhe faz tomar atitudes, primeiramente são seus desejos.

Entretanto, o que são desejos? São sonhos, vontades, necessidades, ambições? Desejo é um objetivo, uma meta a ser alcançada, algo que depois de conquistado mudará o indivíduo que lutou por aquilo, tanto de forma positiva ou negativa, pois a vontade de possuir algo é muito traiçoeira e ilusória já que nossos desejos muitas vezes partem de caprichos ou pressuposições impensadas. Porém, independente do resultado, o desejo é um movimento que busca realizar algo, assim, a explicação psicanalítica esclarece melhor o que é esse sentimento:

"O termo indica um movimento psíquico de caráter afetivo e cognitivo, que através de uma lógica específica dirige-se a constituir, simultaneamente, uma realidade externa e uma realidade interna que são diferentes em relação às já dadas. Neste sentido, o desejo é intelectual e, ao mesmo tempo, sensível, que enquanto tal abre não só à ulterioridade mas também a alteridade." (PIERI, P. F. 2002: 144)

Assim, o desejo é algo que surge em nossa vida pela privação, tanto real quanto ilusória, de um “objeto”, que faremos todos os esforços físicos e intelectuais para alcançar aquilo que nos falta. Transformaremos nossa realidade e moveremos nossa vida para conquistar e manter o objeto desejado ao nosso alcance sempre. E é assim que começa a saga de nossa heroína: buscando, realizando e mantendo aquilo que deseja ao seu lado:

"Assim, jogando a lançadeira de um lado para outro e batendo os grandes pentes do tear para frente e para trás, a moça passava os seus dias. Nada lhe faltava. Na hora da fome tecia um lindo peixe, com cuidado de escamas. E eis que o peixe estava pronto para ser comido." (COLASANTI, M. 2008)

A protagonista dessa narrativa vive só, e talvez não por falta de pessoas que lhe façam companhia, mas por uma própria escolha, já que desde o início da narrativa 
vemos a Moça realizando e construindo tudo o que precisa e deseja sozinha, sem ajuda de ninguém, apenas com seu próprio esforço no seu tear.

A Moça Tecelã não tem uma madrasta que a expulsa de casa ou uma bruxa ciumenta e possessiva que a tranca em uma torre, ou seja, ela não convive com fatores alheios que a force procurar uma libertação, um crescimento interno, a consolidação do seu EU, da sua vontade e anseios; ela não precisa sobrepor-se a nada e ninguém. Ao contrário, sozinha ela vai descobrindo o que precisa e deseja, caso haja muita chuva, ela tece o sol, se está com fome, tece sua comida, se está com sede, tece o vinho, e assim por diante.

Porém, é possível construir uma vida, uma identidade e personalidade sozinho? Todas as análises anteriores mostram que não, a formação interna do indivíduo se faz não apenas a construção histórica e social da humanidade, como também com os conflitos internos causados pelos desafios encontrados no caminho de cada um, que são proporcionados tanto por situações quanto por outras pessoas.

"Mas, embora este auto-desenvolvimento seja meritório, e possa salvar nossa alma, ainda não basta para sermos felizes. Para isso, devemos ultrapassar o isolamento e formar um elo com o outro. Mesmo que vivamos num plano de vida muito elevado, o Eu sem o Tu vive numa existência solitária." (BETTELHEIM, B. 2003: 318)

Em outras palavras, podemos constituir nossa personalidade, identidade e índole sozinhos até certo ponto, porém será uma formação pobre e limitada, o outro é uma fonte rica e necessária, não apenas para o auto-conhecimento e estruturação interna, mas principalmente como forma de realização e felicidade. Um dos maiores aspectos de amadurecimento é a capacidade de construir um elo com outro indivíduo, mas não por necessidade como faz a criança, mas por afinidade, como os adultos saudáveis fazem.

Nenhum indivíduo, mesmo o amadurecido e com a psique bem estruturada, é auto-suficiente emocionalmente, o elo com outros indivíduos se faz muito necessário, pois é isso que indica o quanto alguém é digno de ser amado. Os elos afetivos entre as pessoas demonstram o quanto elas são amadas, queridas, necessárias e importantes; por isso, há sempre a busca pelo outro, pela a corroboração da nossa própria significância.

"Mas, tecendo e tecendo, ela própria trouxe o tempo em que se sentiu sozinha, e pela primeira vez pensou como seria bom ter um marido ao lado." (COLASANTI, M, 2008) 
Assim, esse sentimento de solidão e desejo de sentir-se amada por outro chegou à nossa protagonista. Apesar de construir tudo o que precisava, de mudar as coisas que não lhe agradavam, a Moça sente-se sozinha, todo seu trabalho de tecer já não a preenchia mais; assim ela pensa em um marido, um companheiro. É chegada a sua hora de buscar o outro, de sair da egoicidade e relacionar-se com o outro.

Até essa altura da narrativa, a protagonista mostrou-se capaz de viver absolutamente sozinha, em nenhum momento há menções de família, amigos ou qualquer outro ser em sua vida. A moça vive em um mundo só dela, mas que em determinado momento torna-se solitário, ou seja, esse é o ponto que se inicia o amadurecimento dela, a entrada para a vida adulta.

"O processo de individuação não se faz sem o contato com o outro e com o meio." (VARGAS, N.S. 2007, 213). Então, para que a Moça possa constituir totalmente sua identidade e personalidade, afirmar-se como indivíduo, ela precisa buscar o outro e arriscar-se em um meio em que não pertence somente a ela. Percebendo esse vazio em sua vida, a moça busca o seu companheiro da única maneira que sabia agir: tecer.

"Não esperou o dia seguinte. Com capricho de quem tenta uma coisa nunca conhecida, começou a entremear no tapete as lãs e as cores que lhe dariam companhia." (COLASANTI, M. 2008)

Assim, a moça começa a tecer aquele que ela deseja para estar ao seu lado, escolhendo as cores e lãs, dando-lhe a forma que sua imaginação acredita que a fará feliz. Porém, a simples existência de um outro indivíduo é capaz de fazer uma jovem feliz?

Quem aparece do tear da Moça, ou seja, do desejo dela é um moço com a descrição de príncipe: chapéu emplumado, corpo aprumado, sapato engraxado e rosto barbado. Mas, mal dava o último ponto no tear e o moço meteu a mão na maçaneta da porta e entrou na vida da Moça Tecelã.

O desejo dela havia se tornado realidade e ela estava lá, deitada em seu ombro, imaginando seu futuro feliz com a família que poderiam formar. Entretanto, aquele moço não era como todas as outras coisas tecidas por ela, pois ele também tinha seus desejos e vontades, e logo que descobriu o que a Moça poderia fazer com tear, o moço começou a demonstrar toda sua voluntariosidade.

A Moça tecelã depara-se agora com uma situação totalmente inusitada, nova para ela, já que está à frente de um desejo seu que não se comporta da maneira a qual foi 
idealizado. Primeiramente, ele nem pensa em filhos, mas em uma casa maior para abrigá-los melhor. Começa uma nova fase na vida na Moça, na qual ela precisa saber a como lidar com o outro, com o diferente de si, com o inesperado, co o que não age conforme os desejos dela.

O moço, que então, surgira na vida da Tecelã pelos desejos da mesma, era alguém de próprias vontades e diferentes das dela, mas que não possuía as mesmas habilidades da moça, por isso a convenceu de atendê-lo:

"Porque, descoberto o poder o tear, em nada mais pensou a não ser nas coisas todas que ele poderia lhe dar.

_ Uma casa melhor é necessária _ disse para a mulher. E parecia justo, agora que eram dois. Exigiu que escolhesse as mais belas lãs cor de tijolo, fios verdes para os batentes, e pressa para a casa acontecer." (COLASANTI, M. 2008)

Como em qualquer casamento há mudanças nas vidas dos cônjuges, que iniciam uma nova etapa em suas vidas, com outras responsabilidades e perspectivas; mas as mudanças que ocorrem para a Moça são muito diferentes das planejadas ou esperadas por ela, enquanto que para o moço tudo ocorre dentro de seus desejos e expectativas.

Logo no início do relacionamento mudanças radicais são impostas à Moça, ela que construía sua vida sozinha conforme suas necessidades e desejos, se vê agora unida a outro indivíduo que possui suas próprias necessidades e desejos a se realizarem. Para a Tecelã, essas mudanças são radicais, pois quando ela busca um companheiro, ela acredita que esse será exatamente tudo o que ela sonhara, mas essas expectativas são logo desfeitas e a Moça tem que se adaptar rapidamente ao seu companheiro.

Em frente a uma situação totalmente nova e desconhecida para a Tecelã, o convívio íntimo com outro indivíduo, ela se porta da única forma que conhece e sentese segura: tecendo. Assim, a Moça continua tecendo sua vida, entretanto essa não é mais constituída pelos desejos e necessidades dela, mas dos mandos, desejos e caprichos do moço:

"Mas pronta a casa, já não lhe pareceu suficiente. _ Para que ter casa, se podemos ter palácio? _ perguntou. Sem querer resposta, imediatamente ordenou que fosse de pedra com arremates de prata." (COLASANTI, M. 2008)

Assim, a Moça começa a executar todos os desejos daquele indivíduo que ela mesma havia desejado e tecido para participar de sua vida, ou seja, aquele que foi 
idealizado pela tecelã para realizar vários desejos dela, mas que chega e frustra qualquer perspectiva que havia sobre ele. E em pouco tempo, ela se vê engolida pelas vontades do outro, ela que antes vivia apenas por suas vontades, agora vive apenas pelas vontades do outro. O relacionamento não é construído de forma igualitária, mas ao contrário, de forma massacrante, onde apenas um pode apreciar a vida enquanto ao outro cabe apenas o esforço e sacrifício de manter os deleites do primeiro.

O início da vida amorosa, na maioria das vezes, é demasiadamente idealizado pelas pessoas, há uma tendência em fantasiar a vida conjugal, em que o encontro e convivência com o outro é simples e composta apenas por prazeres, entretanto, a convivência diária com o parceiro irá aos poucos demonstrar que "nem mesmo ser amada por um príncipe garante a felicidade." (BETTELHEIM, B. 2001: 318); a vida a dois é muito mais complicada e penosa do que se imaginava.

"Como quer que a estória seja vivenciada, ela diz que a felicidade conjugal requer que sentimentos inacessíveis à pessoa até o casamento se coloquem a seu alcance. (...), que na última transição necessária para adquirir uma humanidade madura e as repressões devem ser desfeitas." (BETTELHEIM, B. 2001: 322)

Mesmo sendo internamente maduro, o indivíduo pode não escapar da confrontação com determinadas dificuldades na vida a dois, pois "encontrar $a$ realização pelo amor e no amor requer mais uma transição."(BETTELHEIM, B. 2001: 318). Ou seja, para alcançar a realização pessoal em um relacionamento amoroso é necessário também amadurecer dentro dele, é preciso encontrar seu novo espaço e função e entender-se nessa nova etapa na vida para ser feliz.

Para tanto, muitas vezes, o indivíduo precisa vivenciar certas experiências a dois para aprender e entender quais elementos emocionais estão envolvidos em um relacionamento amoroso, quais são as expectativas e cobranças em um casamento. As pessoas têm algumas noções daquilo que a esperam nesse relacionamento, porém somente no cotidiano marital é que realmente compreenderão como vivenciá-lo.

A heroína dessa narrativa possui suas expectativas sobre o casamento, nas quais, além de depositar sua felicidade no compartilhamento de sua vida e sonhos com o companheiro, ela também acredita que o companheiro escolhido terá as mesmas expectativas que ela, ou seja, ambos desejam e esperam o mesmo para suas vidas. 
"Aquela noite, deitada contra o ombro dele, a moça pensou nos lindos filhos que teceria para aumentar ainda mais a sua felicidade. E feliz foi, durante algum tempo. Mas se o homem tinha pensado em filhos, logo os esqueceu. Porque, descoberto o poder do tear, em nada mais pensou a não ser nas coisas todas que ele poderia lhe dar." (COLASANTI, M. 2008)

Enquanto a moça pensava em construir uma vida afetiva com um companheiro e uma família, o homem estava interessado apenas em acumular bens materiais, objetivo esse claramente oposto ao da tecelã. Dessa forma, o desencontro do casal não poderia ser maior, pois ao invés de se aproximarem, afastavam-se cada vez mais um do outro com suas tão diversas expectativas.

Entretanto, a moça não percebeu que os objetivos e expectativas de seu companheiro eram outras, e assim, continuou o relacionamento, deixando-se dominar pelo outro e abriu mão, pouco a pouco, de seus desejos, expectativas e objetivos em detrimento da realização apenas das vontades do outro.

Nesse momento, quando ela não consegue mais distinguir que suas expectativas são diferentes das de seu companheiro, a moça torna-se prisioneira, tanto dos desejos do outro, quanto dos dela, pois ela permanece no casamento esperando que em algum momento seus planos também serem realizados.

"Afinal, o palácio ficou pronto. E, entre tantos cômodos, o marido escolheu para ela e seu tear o mais alto quarto da mais alta torre.

- É para que ninguém saiba do tapete - disse. E antes de trancar a porta à chave, advertiu: - Faltam as estrebarias. E não se esqueça dos cavalos!" (COLASANTI, M. 2008)

Em pouco tempo, a moça tecelã tornou-se prisioneira das suas próprias criações, ela estava trancada em uma torre tecida por ela, por ordem e desejo de seu companheiro, ironicamente, também tecido por ela. Tudo que ela deseja, tecia e era feliz assim, porém, de uma forma ou de outra, o tecer não lhe trazia mais felicidade.

A partir do momento em que a moça tece o príncipe, ela deixa de se preocupar com seus demais anseios e entrega-se totalmente ao companheiro, ao relacionamento como se isso fosse o seu maior e melhor desejo a ser realizado. A tecelã deixou-se levar pelo seu companheiro como se a simples existência dele em sua vida a pudesse realizar de forma absoluta, que ela não precisaria preocupar-se com mais nada, como se ela tivesse alcançado o ápice de realização de seus sonhos, que desse companheiro tão desejado emanaria diversas outras fontes de felicidade. 
"Sem descanso tecia a mulher os caprichos do marido, enchendo o palácio de luxos os cofres de moedas, as salas de criados. Tecer era tudo o que fazia. Tecer era tudo o que queria fazer." (COLASANTI, M. 2008)

Como dito anteriormente, tecer aqui significa viver, sendo assim, a moça realmente não poderia ser mais feliz, pois ela não tecia os seus próprios desejos, apenas os do príncipe. Assim, ela não estava vivendo sua vida, mas a do outro. Ela seguia e cumpria apenas expectativas e objetivos alheios de si mesma; ela parou de ouvir suas necessidades para suprir todas de seu companheiro, levando-a ao sentimento de solidão e perda de liberdade.

Dessa forma, a moça tecelã deixou de pensar e desejar coisas para si, ela não tecia mais seus dias como antes, ela não escolhia as linhas e o que seria bordado com elas, ao contrário,quem fazia isso era o marido; a moça tecia apenas os desejos do marido, ela vivia para realizar as expectativas e sonhos desse homem. Após algum tempo de convivência ela, então, percebeu não terem nada em comum, não havia nenhum sonho ou objetivo que ambos compartilhassem: enquanto ele queria ampliar seus bens, aumentar o castelo, ela havia apenas desejado em ter uma família.

"E tecendo, ela própria trouxe o tempo em que sua tristeza lhe pareceu maior que o palácio com todos seus tesouros. E pela primeira vez pensou como seria bom estar sozinha de novo." (COLASANTI, M. 2008)

O matrimônio é a forma de vida em comum entre um casal, em outras palavras, os cônjuges dividem muitas coisas importantes, tanto de cunho material, como também emocional. Mas para que esse relacionamento seja saudável e feliz, os cônjuges precisam ouvir um ao outro e estarem atentos as necessidades e expectativas do outro, ou seja, é muito importante que haja cumplicidade entre o casal, caso contrário, a união é desfeita; pois ela perde o sentido.

E isso aconteceu com a moça tecelã, seu relacionamento com o marido perdeu o sentido, pois ele, que havido sido desejado para constituir uma família e trazer-lha felicidade; apenas a sufocava e impunha-lhe tarefas desgastantes. O casal não dividia anseios ou sentimentos, mas apenas bens materiais, que eram providos com muito esforço pela tecelã e desfrutados somente pelo príncipe. Assim, não havia uma vida em comum entre o casal, só o interesse do marido de ter uma vida rica e a ilusão da tecelã de criar uma família. 
"Desta vez não precisou escolher linha nenhuma. Segurou a lançadeira ao contrário e, jogando-a veloz, de um lado para o outro, começou a desfazer seu tecido. Desteceu os cavalos, as carruagens, as estrebarias, os jardins. Depois desteceu os criados e o palácio e todas as maravilhas que continha. E novamente se viu na sua casa pequena e sorriu para o jardim além da janela." (COLASANTI, M. 2008)

No momento em que a tecelã entendeu não haver cumplicidade e interesses em comum com seu marido, ela desfaz tudo aquilo que havia tecido pela vontade dele, ou seja, ela desfaz a união. A tecelã libertar-se da torre e das vontades do outro, pensa em si mesma e procura ficar com apenas seus desejos, com aquilo que a torna satisfeita, feliz. Dessa forma, aquele homem não tem mais espaço em sua vida, então é desfeito também:

"A noite acabava quando o marido, estranhando a cama dura, acordou e, espantado, olhou em volta. Não teve tempo de se levantar. Ela já desfazia o desenho escuro dos sapatos, e ele viu seus pés desaparecendo, sumindo as pernas. Rápido, o nada subiu-lhe pelo corpo, tomou o peito aprumado, o emplumado chapéu." (COLASANTI, M. 2008)

A tecelã que havia desejado tanto um príncipe, um marido, um companheiro para viver feliz ao seu lado e construir uma família, escolheu os fios e teceu esse homem, acreditando que isso bastaria para realizar seu sonho. Porém, isso não fora suficiente, e, agora ela se desfazia de tudo que havia tecido, pois cada ponto representava somente os desejos e necessidades do marido, não havia mais nenhum esboço tecido por ela para suprir suas expectativas dela.

Assim, se o matrimônio é a forma de vida em comum de um casal, pode-se perguntar: o que os dois compartilhavam? Nada. A moça tecelã simplesmente cumpria as exigências do príncipe, sendo esse um relacionamento de dominação e submissão, e não entre iguais com interesses e preocupações em comum. Portanto, se nada os unia facilmente os pontos que os mantinham perto foram desfeitos pela moça, deixando-a novamente sozinha, quase no mesmo lugar que estava antes da chegada do marido.

"Então, como se ouvisse a chegada do sol, a moça escolheu uma linha clara. E foi passando-a devagar entre os fios, delicado traço de luz, que a manhã repetiu na linha do horizonte." (COLASANTI, M. 2008)

A moça encontra-se novamente só e tecendo da forma que deseja, ela que tentara tecer uma estória de amor, de entrega e felicidade, acabara se desiludindo, não 
encontrou o que esperava e não viveu o desejado. Mas, o que poderia parecer uma estória mal sucedida com um enlace triste, na verdade é uma amostra de esperança, de possibilidade na vida; pois se a moça não conseguiu atingir o desejado, ela tem agora a chance de recomeçar, de tentar novamente, desvencilhando daquilo que trouxera infelicidade e reconstruir seu caminho, mas agora sabendo o que lhe faz mal e o que lhe faz bem. 


\title{
VII) CONSIDERAÇÕES FINAIS.
}

\begin{abstract}
"O amor era uma grande questão para mim. Eu não era capaz nem de pensar sobre esse tema quando era adolescente - lia tudo que podia sobre isso. Uma coisa que me ajudou foram os contos de fadas, todos com lindas idéias sobre relacionamento, sobre como alguém pode se sentir confortável onde vive. Por meio dessas histórias, eu gradualmente me tornava hábil para entender o amor." (Daniel Tammet, Folha Equilíbrio in Folha de São Paulo, 10 de janeiro de 2008)
\end{abstract}

Essa declaração foi feita por um jovem de vinte e oito anos, diagnosticado com a síndrome de Asperger, um tipo mais brando de autismo, a qual prejudica o indivíduo nos relacionamentos interpessoais, pois eles são extremamente lógicos e metódicos, não se adequando muito bem aos imprevistos cotidianos e incoerências alheias. Porém, esse jovem encontrou nos contos de fadas uma forma de contornar sua própria condição e compreender algo que sozinho não conseguiria fazer.

Ao longo da dissertação, particularmente, das análises das obras escolhidas, procurei apontar justamente a experiência vivenciada por esse rapaz. Mediante as reflexões feitas nesse estudo os contos de fadas são tão atuais e conhecidos porque nos apontam caminhos, nos dão alento e ainda nos preparam para os desafios da vida.

Entretanto, isso não significa que a literatura infanto-juvenil está reduzida a uma sala de aula, ou seja, algo que pretende apenas ensinar, doutrinar ou passar valores aos mais jovens ou inexperientes. Ao contrário, a literatura, como toda forma artística, é um meio, uma forma daqueles mais sensíveis, experientes e talentosos materializarem e compartilharem sentimentos, noções e valores comuns a todos.

Nas narrativas interpretadas no corpus dessa dissertação, mesmo o enfoque sendo o universo feminino, todos os leitores ou ouvintes dessas narrativas podem se reconhecer, identificar ou simpatizar com as situações ou personagens. Afinal, quem nunca experimentou o sentimento de raiva ou inveja em relação a própria mãe, ou não se sentiu extremamente só e abandonado, como estivesse em um deserto, em momentos difíceis do cotidiano. Quem nunca fez uma opção equivocada, seguiu com ela e quando não suportava mais as conseqüências trazidas por ela, o que mais desejou foi uma nova chance de recomeçar, apagar o passado e reescrever sua história.

Os contos de fadas tratam disso e muito mais, essas narrativas de origem indeterminada, passadas oralmente por gerações, posteriormente escritas, e atualmente repaginadas são estórias da humanidade, ou seja, elas tratam liricamente tudo o que é 
mais belo, complexo e misterioso dos indivíduos. Os contos de fadas materializam os sentimentos humanos, são eles que nos colocam de forma maravilhosa e mágica diante dos aspectos que constituem a base humana, aqueles contraditórios que permeiam em nossa existência: o trágico e o sublime, o ódio e o amor, a inveja e a abnegação...

Sendo assim, a mulher personagem nessas narrativas é sim um esboço, um reflexo de muitas mulheres de carne e osso. As personagens aqui analisadas estão presentes um pouco, de uma forma ou outra, em situações nas meninas e mulheres reais; essas personagens não foram construídas somente da imaginação popular, elas foram crescendo e tomando forma com as experiências e observações dos narradores que as imortalizaram. 


\section{VIII) BIBLIOGRAFIA}

BAKHTIN, Mikhail. Estética da criação verbal. São Paulo: Martins Fontes, 2003.

BETTELHEIM, Bruno. A psicanálise dos contos de fadas. Rio de Janeiro: Paz e Terra, 2003.

BONAVENTURE, Jette. Variações sobre o tema mulher. São Paulo: Paulus, 2000.

BRUNEL, Pierre (org.). Dicionário de Mitos Literários. Rio de Janeiro: José Olympo Editora, 1988.

CASCUDO, Luís da Câmara. Contos Tradicionais do Brasil. São Paulo: Editora Global, 2004.

CHEVALIER, Jean \& Alain Gueerbrant. Dicionários de símbolos. Rio de Janeiro: José Olympio Editora, 2008.

CIRLOT, Juan-Eduardo. Dicionário de Símbolos. São Paulo: Editora Centauro, 2007.

COELHO, Nelly Novaes. O conto de fadas. São Paulo: Editora Ática, 1987.

COLASANTI, Marina. A Moça Tecelã. São Paulo: Editora Global, 2004.

CORSO, Diana L. \& Mário. Fadas no Divã. Psicanálise nas histórias infantis. Porto Alegre: Artmed, 2006.

ELIADE, Mircea. Mito e Realidade. São Paulo: Editora Perspectiva, 1997.

FREUD, Sigmund. A consciência e o que é inconsciente. In Obras Completas. Rio de Janeiro: Imago Editora, 1976. 
GRIECO, S. in DUBY \& PERROT, Georges \& Michelle (orgs.). História das

Mulheres no Ocidente.Volume 3: Do Renascimento à Idade Moderna. Porto:

Edições Afrontamento, 1991.

GRIMM, Jacob \& Wilhelm. Branca de Neve. In Obras Completas. Rio de Janeiro: Editora Itatiaia, 2000.

. Rapunzel. In Obras Completas. Rio de Janeiro: Editora Itatiaia, 2000.

HENDERSON, J.L. in JUNG. C.G.(org). O homem e seus símbolos. Rio de Janeiro: Editora Nova Fronteira, 2008.

HIGONNET, A. in DUBY \& PERROT, Georges \& Michelle (orgs.). História das Mulheres no Ocidente.Volume 4: O século XIX. Porto: Edições Afrontamento, 1991.

HOUAISS, Antônio. Dicionário da Língua Portuguesa. Rio de Janeiro: Editora Objetiva, 2001.

HUFTON, O. in DUBY \& PERROT, Georges \& Michelle (orgs.). História das Mulheres no Ocidente.Volume 3: Do Renascimento à Idade Moderna. Porto: Edições Afrontamento, 1991.

JUNG, C. Gustav. Os arquétipos e o inconsciente coletivo. Petrópolis: Editora Vozes, 2006.

KNIBIEHELER, Y. in DUBY \& PERROT, Georges \& Michelle (orgs.). História das Mulheres no Ocidente.Volume 4: O século XIX. Porto: Edições Afrontamento, 1991.

PIERI, Paolo Francesco (org.). Dicionário Junguiano. Rio de Janeiro: Editora Vozes, 2002.

PROPP, Vladimir. As raízes históricas do conto maravilhoso. São Paulo: Martins 
Fontes, 2002.

. Morfologia do Conto Maravilhoso. Rio de Janeiro: Editora Forense Universitária, 2006.

ROMERO, Sílvio (org.). Contos Populares do Brasil. São Paulo: Editora Landy, 2002.

ROSENFELD, Anatol. A personagem de ficção. São Paulo: Editora Perspectiva, 2002.

TODOROV, Tzevetan. As estruturas narrativas. São Paulo: Editora Perspectiva, 2004.

VON FRANZ, Marie-Louise. A sombra e o mal nos contos de fada. São Paulo: Paulus, 2002.

WARNER, Marina. Da fera à loira. Sobre contos de fadas e seus narradores. São Paulo: Companhia das Letras, 1999. 
IX) ANEXOS 
ANEXOS 


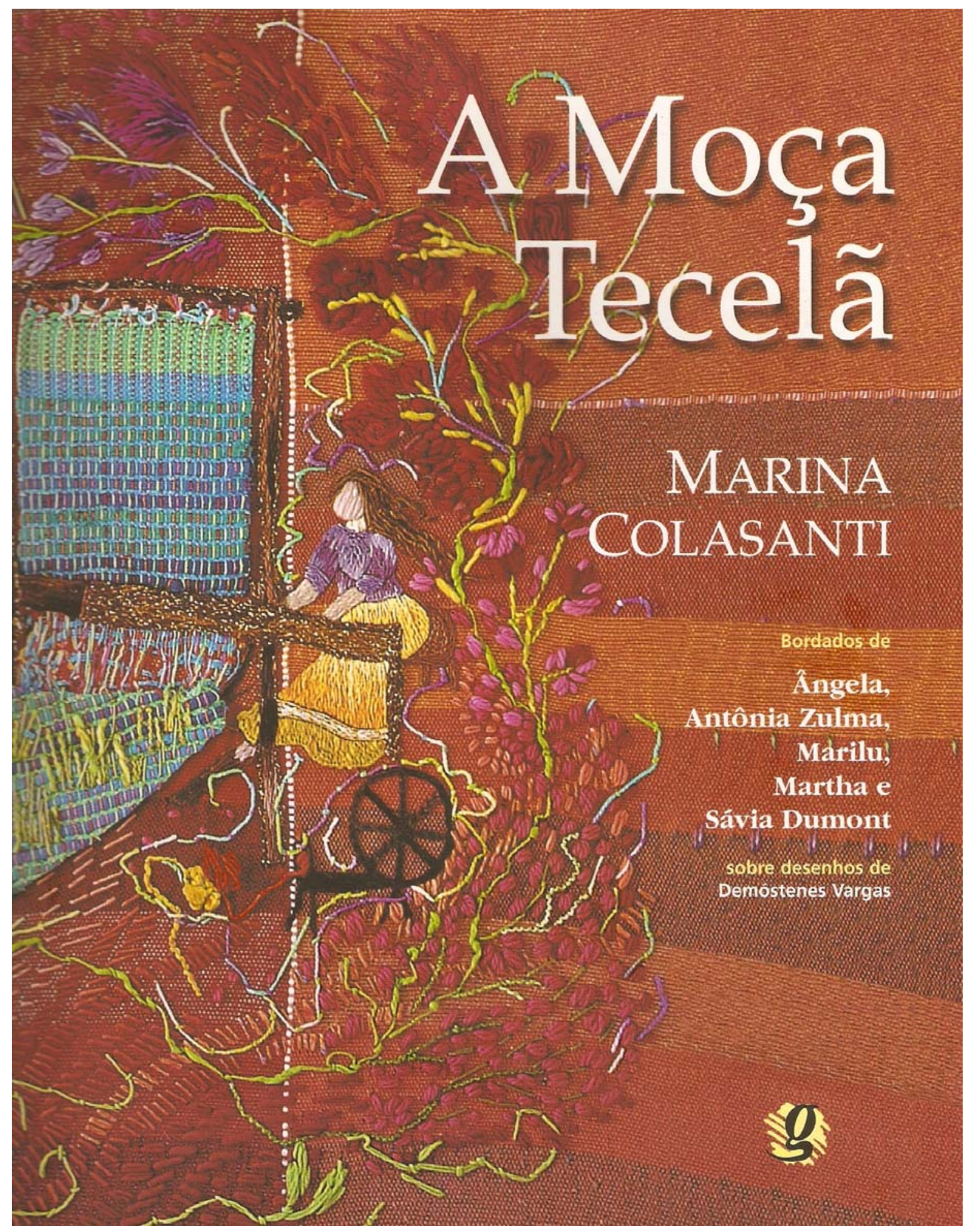




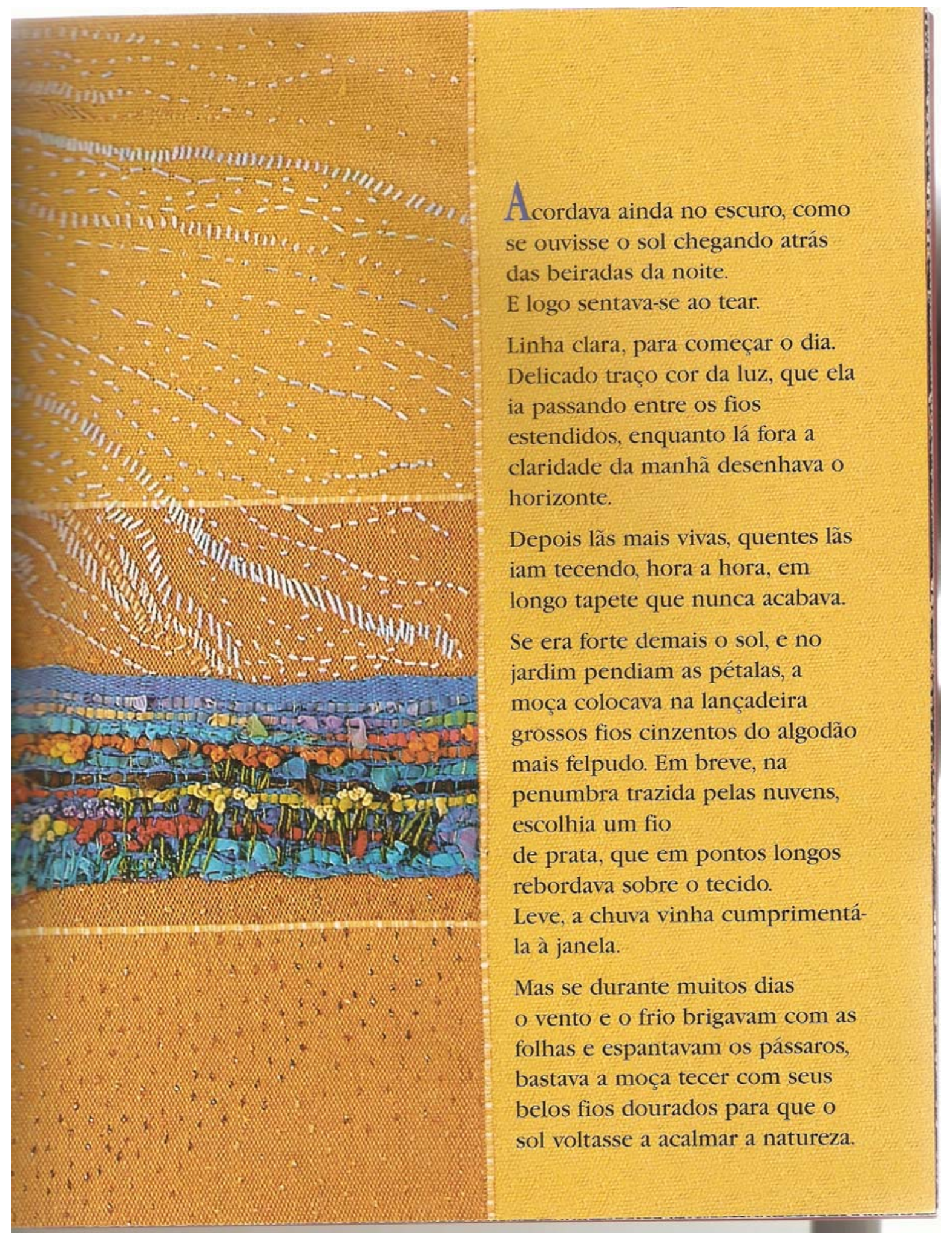




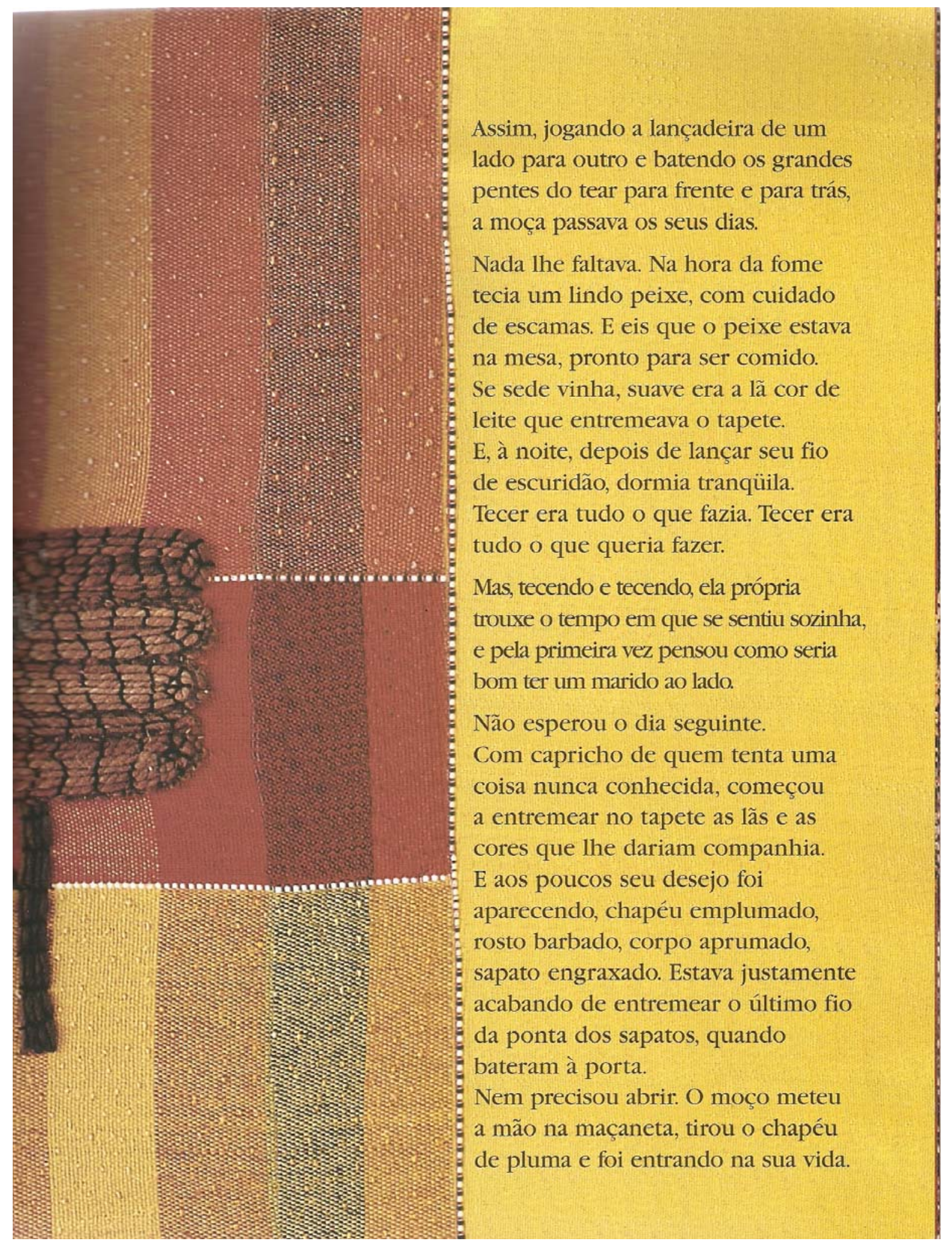


Aquela noite, deitada contra o ombro dele, a moca pensou nos lindos fillos que teceria para aumentar ainda mais a sua felicidade

E feliz foi durante algun tempo. Mas se o homem tinha pensado em filhos, logo os esquecen. Porque, descoberto o poder do tear em nada mais pensou a náo ser nas coisas todas que ele poderia lie dar:

- L na casa melhor e necessatia - cisse para a mullier E parecia justo, agora que eram dois. Exigill que escollhesse as mais belas lass cor de tijolo, fies verdes para os batentes, $e$ pressa pata a casa acontecer Mas pronta a casa. ja nâo llie pareceu suficiente. - Para que ter casa, se podemos ter palácio? - perguntou. Sem querer resposta, imediatamente ordenou que fosse de pedra com arremates em prata.

Dias e dias semanas e neses trabalhou a moca tecendo tetos e portas e patios e escadas $\mathrm{e}$ salas e poços. A neve caia lá fora. e ela nao tinha tempo para chamar o sol. A noite chegava, e ela não tinha tempo para arrematar o dia. Tecia e entristecia, enquanto sem parar batiam os pentes acompanhando o ritmo da lançadeira. 


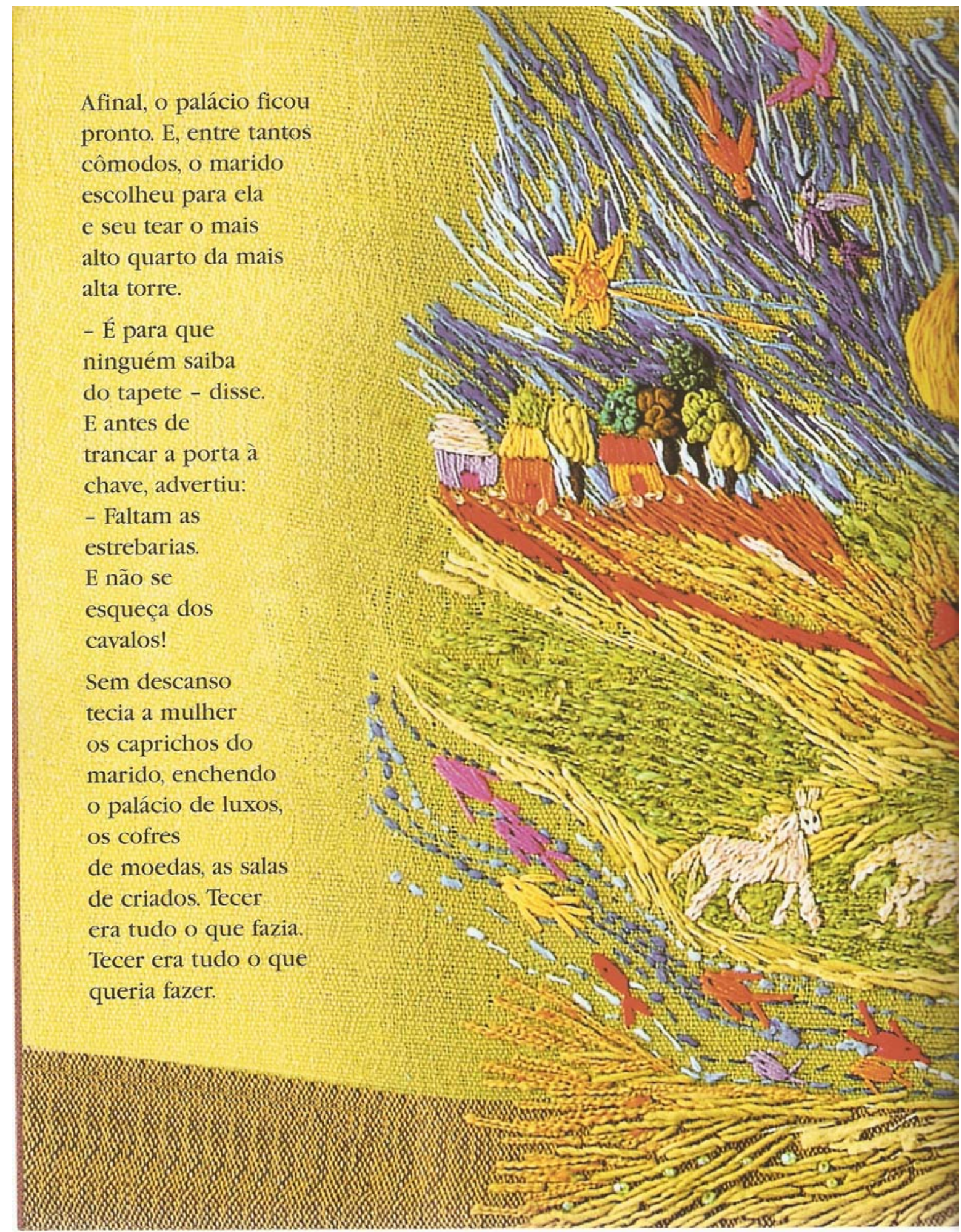




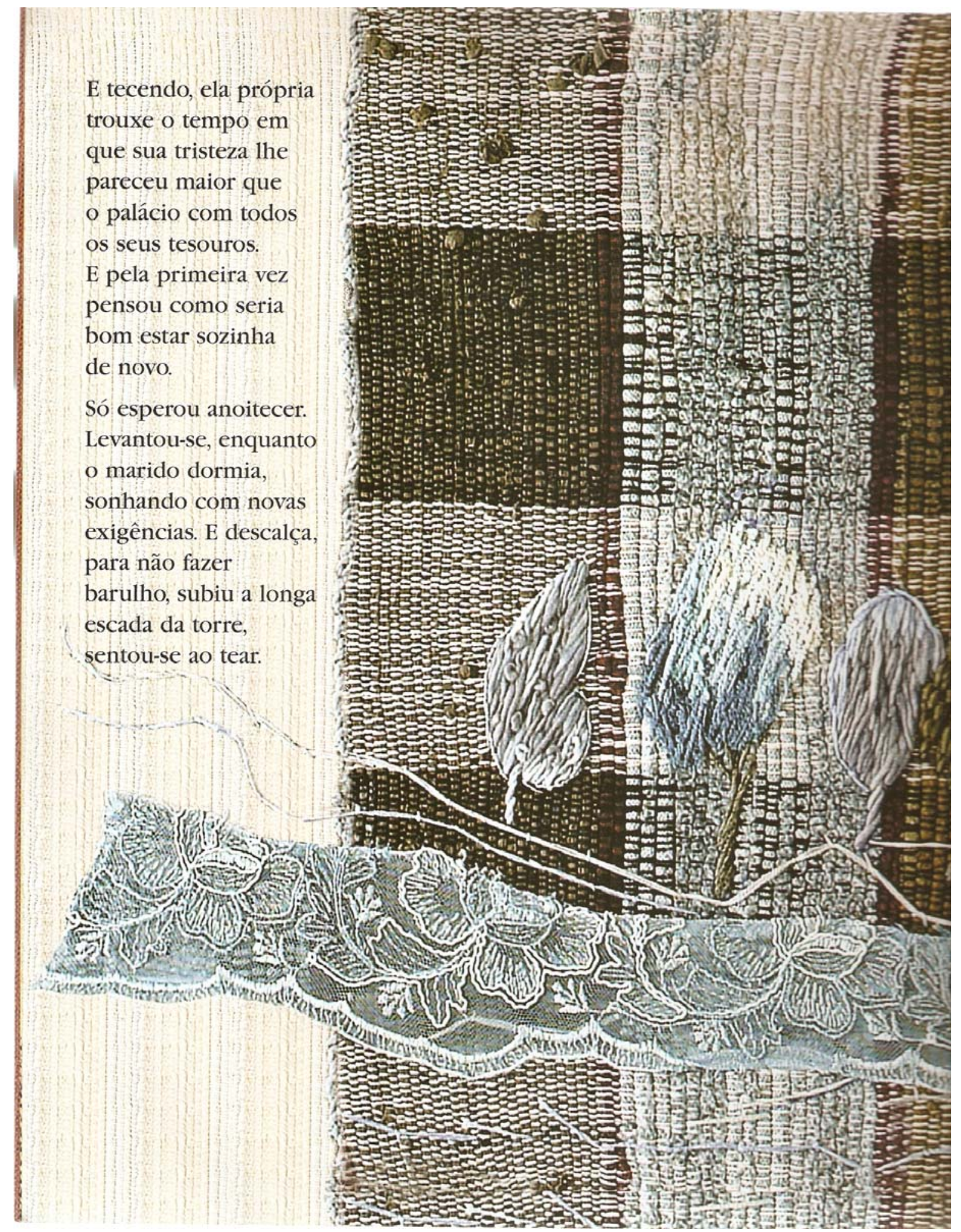




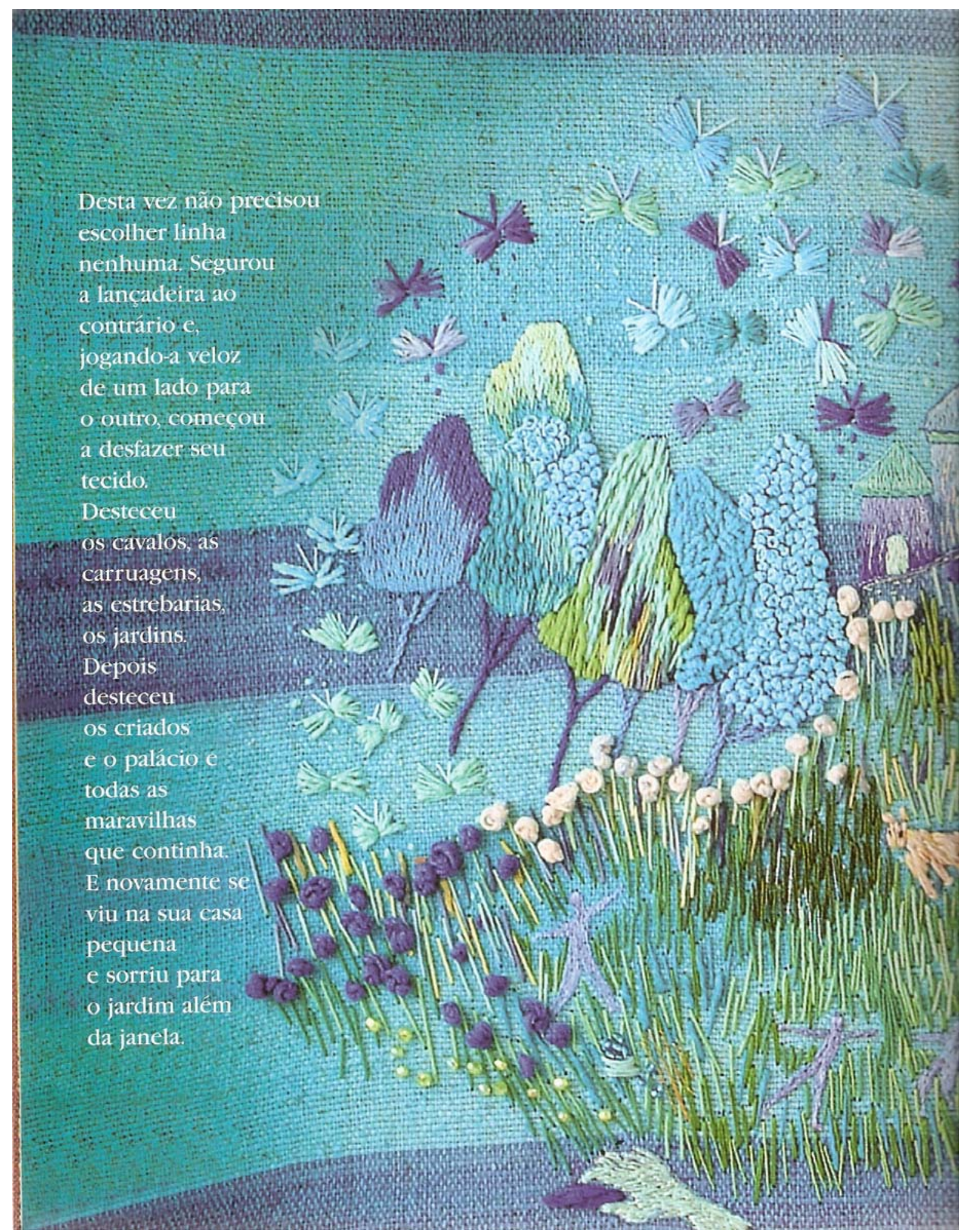




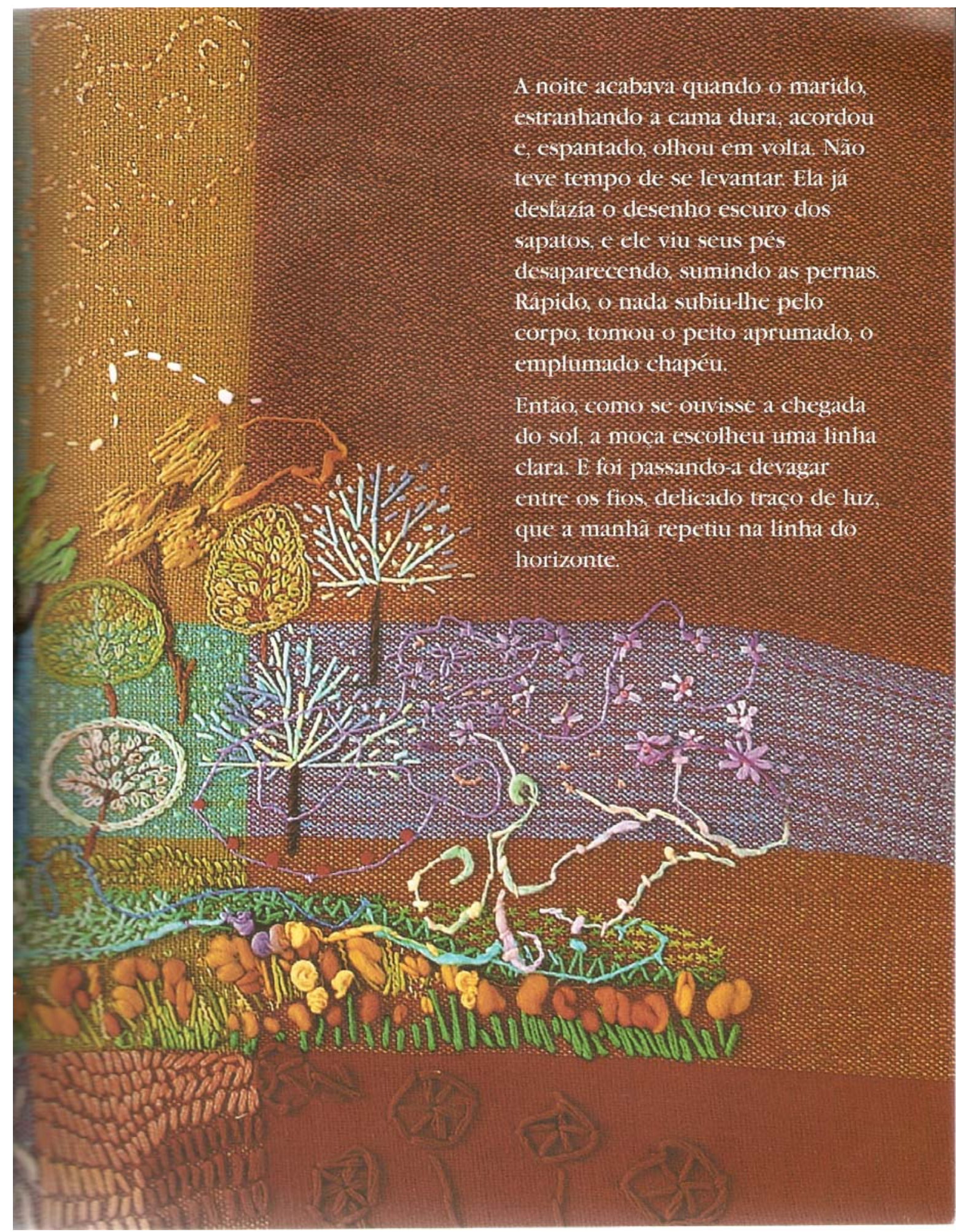


61.

\section{BRANCA DE NEVE}

Era uma vez uma rainha que, certo dia, no meio do inverno, quando flocos de neve caíam do céu como se fossem penas, costurava sentada junto da janela, cujo caixilho era de ébano muito negro. E, enquanto costurava e olhava pela janela, espetou o dedo na agulha e três gotas de sangue caíram na neve. E ela pensou, então:

"Quem me dera ter uma filha branca como a neve, vermelha como o sangue e negra como o caixilho da janela?"

Pouco depois, deu à luz a uma filha que tinha a cútis tão alva como a neve e tão corada como o sangue, e cujos cabelos eram negros como o ébano, e ficou chamando Branca de Neve. E, quando deu à luz a criança, a rainha morreu.

Passado um ano, o rei casou-se de novo. Sua segunda mulher era bela, mas altiva e orgulhosa, não admitia que nenhuma outra mulher fosse mais formosa do que ela. Tinha um espelho encantado, diante do qual ficava se contemplando horas seguidas e perguntava:

Dize a pura verdade, dize, espelho meu:

Há no mundo mulher mais bela do que eu?

E certo dia, o espelho respondeu:

Aqui neste quarto sois vós, com certeza,

Mas Branca de Neve possui mais beleza.

A rainha ficou lívida de raiva e de inveja. $\mathrm{E}$, desde aquele momento, odiou Branca de Neve.

O ódio foi crescendo em seu coração de tal maneira que ela não teve mais sossego: noite e dia invejava a beleza da princesinha, revoltava-se de ser menos formosa do que ela, não se resignava de modo algum. 


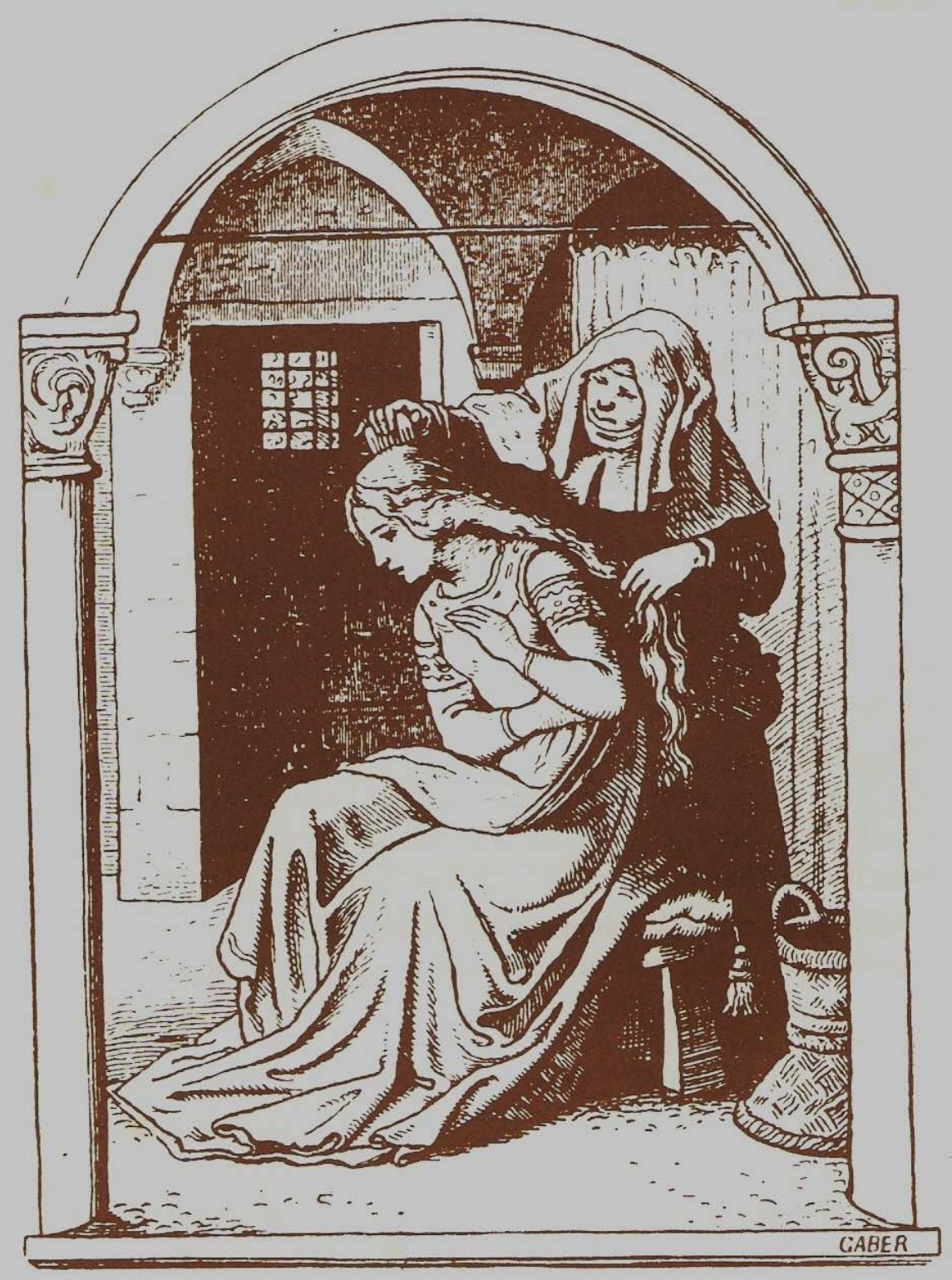


Afinal, um dia chamou um caçador e disse-lhe:

- Leva a menina para a floresta, bem longe. Não suporto mais vê-la perto de mim. Mata-a e, como prova de que cumpriste a minha ordem, traze-me o seu pulmão e o seu fígado.

O caçador obedeceu e levou a menina para a parte mais espessa da floresta. Quando, porém, ia atravessar com a faca o inocente coração da menina, Branca de Neve, chorando, implorou:

— Não me mates, caçador! Prometo entrar cada vez mais pela floresta e nunca mais voltar para casa!

Vendo-a, tão bela e tão jovem, o caçador teve pena e soltou-a, dizendolhe:

- Foge, foge, pobre criança!

E acrescentou, baixinho, sem que ela ouvisse:

— As feras não tardarão a devorar-te.

Sentia, no entanto, ter retirado um peso da consciência. E, como aparecesse um filhote de urso caminhando em sua direção, matou-o com uma facada e retirou o pulmão e o fígado, que apresentou à rainha, como prova de que a menina estava morta. O cozinheiro os salgou e a perversa madrasta de Branca de Neve os comeu, pensando que devorara o pulmão e o fígado da enteada.

Enquanto isso, a pobre menina vagava sozinha pela floresta, apavorada, sem saber o que fazer, até que saiu correndo loucamente, entre espinheiros e pedras aguçadas. Não se feriu, no entanto, e caminhou enquanto teve força nas pernas.

Quando parou, já estava anoitecendo. Olhou em torno e viu uma pequena cabana e lá entrou, para descansar um pouco. Tudo lá dentro era pequeno, mas tudo muito limpo e muito arrumado. Havia uma mesinha, coberta por uma toalha e sete pratinhos, tendo ao lado uma colherinha, além de sete faquinhas e sete garfinhos e sete copinhos. Encostadas na parede, estavam sete caminhas, cobertas por colchas brancas como a neve.

Branca de Neve estava com tanta fome e tanta sede, que não resistiu e tirou um pouquinho da comida de cada prato e um pouquinho de vinho em cada copo, pois não queria tomar tudo de um só. Depois, muito cansada 
como estava, deitou-se em uma das caminhas, mas todas eram pequenas demais para o seu corpo, com exceção da sétima, na qual, com algum esforço e muita boa vontade, conseguiu se acomodar. E lá ficou. Rezou, fechou os olhos, e não tardou a dormir.

Já era noite fechada quando os donos da cabana voltaram. Eram sete anões, que trabalhavam como mineiros, retirando minerais das montanhas. Eles acenderam sete velas, e, quando o interior da cabana ficou iluminado, notaram que alguém estivera ali, pois não encontraram as coisas como as haviam deixado.

- Quem andou sentando em minha cadeira? - perguntou o primeiro.

E o segundo:

- Quem andou comendo no prato?

O terceiro:

— Quem tirou um pedaço do meu pão?

O quarto:

- Quem andou comendo meus legumes?

O quinto:

- Quem andou usando meu garfo?

O sexto:

- Quem andou comendo com a minha faca?

O sétimo:

- Quem andou bebendo meu vinho?

Então, o primeiro dos anõezinhos olhou em torno e viu que o colchão de sua cama estava afundado no meio.

- Quem andou sentando em minha cama? - perguntou.

Os outros anōes notaram que o mesmo acontecera em suas camas e fizeram a mesma pergunta, menos o último deles que, ao examinar a sua cama, viu Branca de Neve deitada e dormindo. Chamou, então, os outros, que vieram, cada um com uma vela acesa na mão, e, quando as velas iluminaram em cheio Branca de Neve, todos exclamaram ao mesmo tempo:

- Meu Deus do céu, que menina linda! 
Ficaram muito alegres e não acordaram a menina. O sétimo anão passou a noite dormindo na cama dos companheiros, uma hora com cada um, a fim de que todos contribuíssem igualmente para ajudá-lo.

Quando amanheceu, Branca de Neve acordou, e ficou assustada, vendo os sete anões. Eles, porém, se mostraram muito amáveis e quiseram saber o seu nome.

- Eu me chamo Branca de Neve - ela respondeu.

- Por que vieste aqui para a nossa casa? - perguntaram também.

A menina contou, então, tudo que lhe acontecera. Como sua perversa madrasta mandou matá-la, mas o caçador encarregado de executar a sinistra missão tivera pena dela e a deixara fugir, e ela andara desorientada pela floresta, até encontrar aquela casa.

- Se quiseres cuidar da nossa casa, cozinhar, fazer as camas, lavar nossa roupa e costurá-las quando houver necessidade, trazendo tudo muito limpinho e asseado, poderás ficar conosco e nada te faltará - propuseram os anões.

\section{\#-Quero muito - concordou a menina.}

E ficou morando com os anões. Tomava conta da casa com a maior boa vontade, mantendo tudo limpo e bem arrumado. De manhã cedo, os anões iam às montanhas para mineirar, retirando cobre e ouro das galerias que abriam na terra. Voltavam no fim da tarde, e o seu jantar tinha de estar prontinho quando chegavam em casa.

Branca de Neve ficava sozinha o dia inteiro, e por isso os anões, que tinham se afeiçoado muito a ela, sempre recomendavam:

- Cuidado com tua madrasta. Ela vai acabar descobrindo onde estás. Toma cuidado para não a deixares entrar, se por acaso vier aqui.

A rainha, porém, acreditando que havia comido o pulmão e o fígado da enteada, estava convencida de que voltara a ser a mulher mais bonita do mundo. E um dia voltou a perguntar ao espelho encantado:

Dize a pura verdade, dize, espelho meu:

Há no mundo mulher mais bela do que eu?

E o espelho respondeu:

Entre as que vejo és a mais bela.

Com sete anōes, tua enteada 


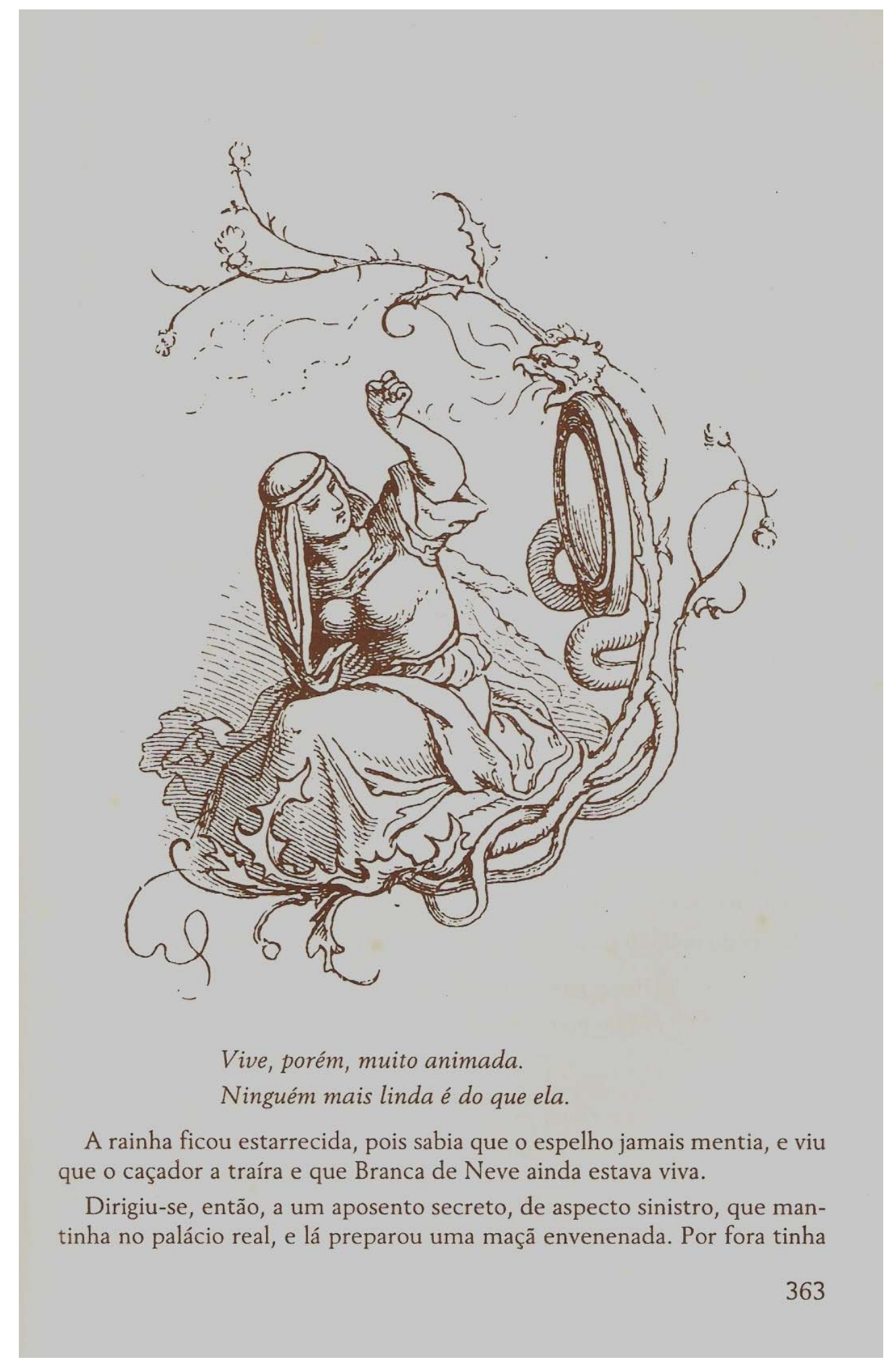


um aspecto perfeito, com toda a aparência de uma maçã bem madura e muito saborosa. Por dentro, porém, era o contrário, e um pedacinho dela era suficiente para matar de pronto quem o comesse.

E, quando a maçã ficou pronta, a malvada madrasta pintou o rosto e se vestiu como se fosse uma camponesa, e conhecendo, graças à sua arte diabólica onde a enteada se encontrava, atravessou a floresta, até chegar à casa dos sete anões. Bateu na porta. Branca de Neve enfiou a cabeça na janela e disse:

- Não posso deixar entrar pessoa alguma. Os sete anões me proibiram.

— Não preciso de entrar - replicou a madrasta. — Estou só querendo te dar uma das maçãs que me sobraram.

— Não — respondeu a enteada. - Não aceitarei coisa alguma.

— Estás com medo de veneno? — insistiu a rainha. — Olha. Vou cortar a maçã em dois pedaços. Ficas com a parte que tem a casca vermelha e eu como a que tem a casca clara.

A maçã fora preparada com tanta habilidade, que só a parte que tinha a casca vermelha foi que ficou envenenada. Branca de Neve olhou para a maçã e seu aspecto era tão apetitoso, que fazia realmente dar água na boca. A menina não resistiu muito: enfiou a mão pela janela e pegou o pedaço de maçã. Mal levou o pedaço à boca, caiu morta.

A rainha olhou-a com o ódio ainda refletido nos olhos e dobrou uma gargalhada satânica.

- Tens a cútis cor de neve, o colorido cor da rosa e os cabelos cor de ébano, mas aí estás, morta e bem morta!

E, tendo voltado para o seu quarto, consultou o espelho mágico:

Dize a pura verdade, dize, espelho meu:

Há no mundo mulher mais bela do que eu?

E ouviu a resposta:

Em verdade não há, no mundo, com certeza,

Tão bela quanto vós ou rainha ou princesa.

Seu invejoso coração ficou em paz diante disso, se é que um coração invejoso pode ficar em paz. 


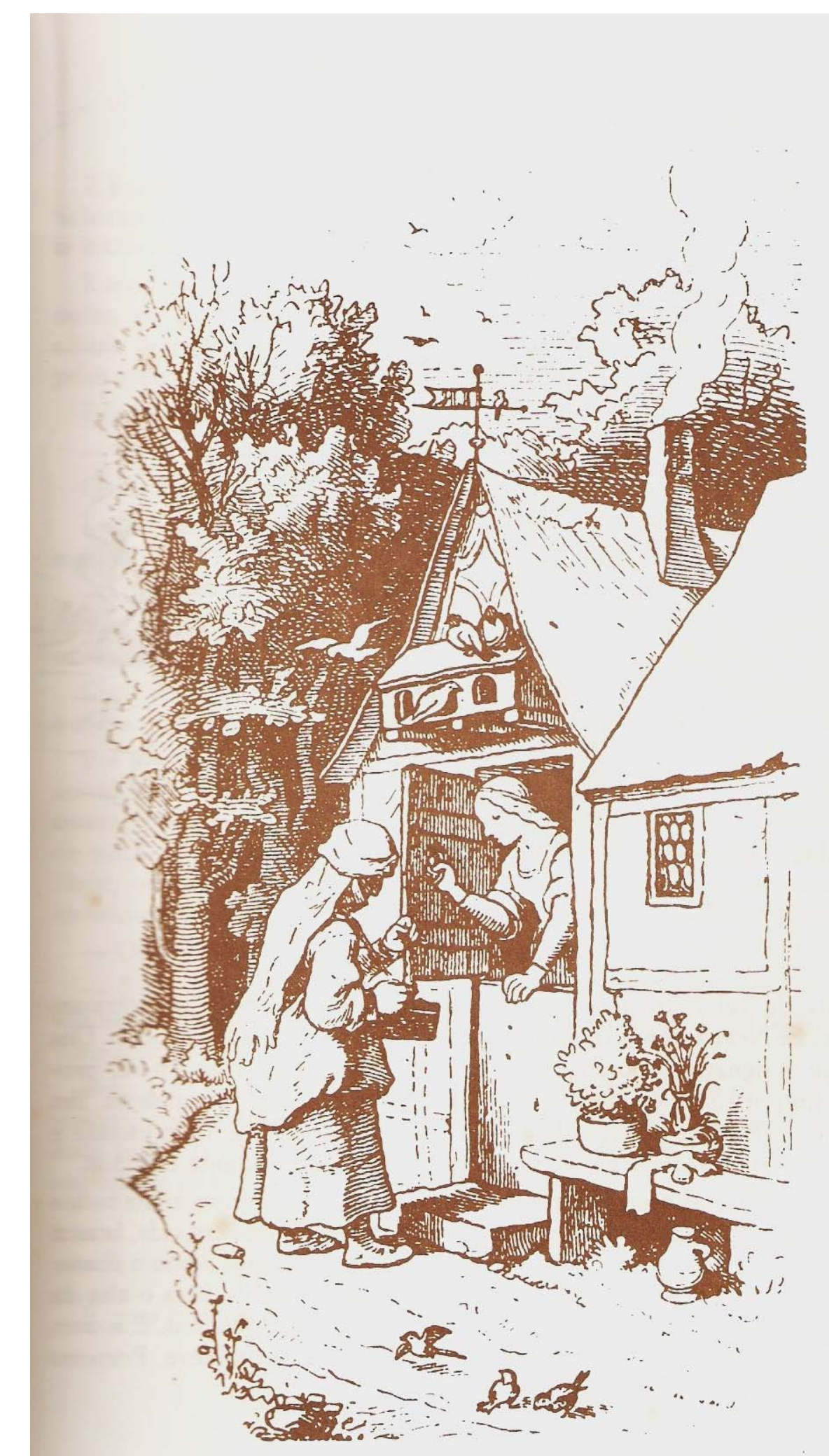




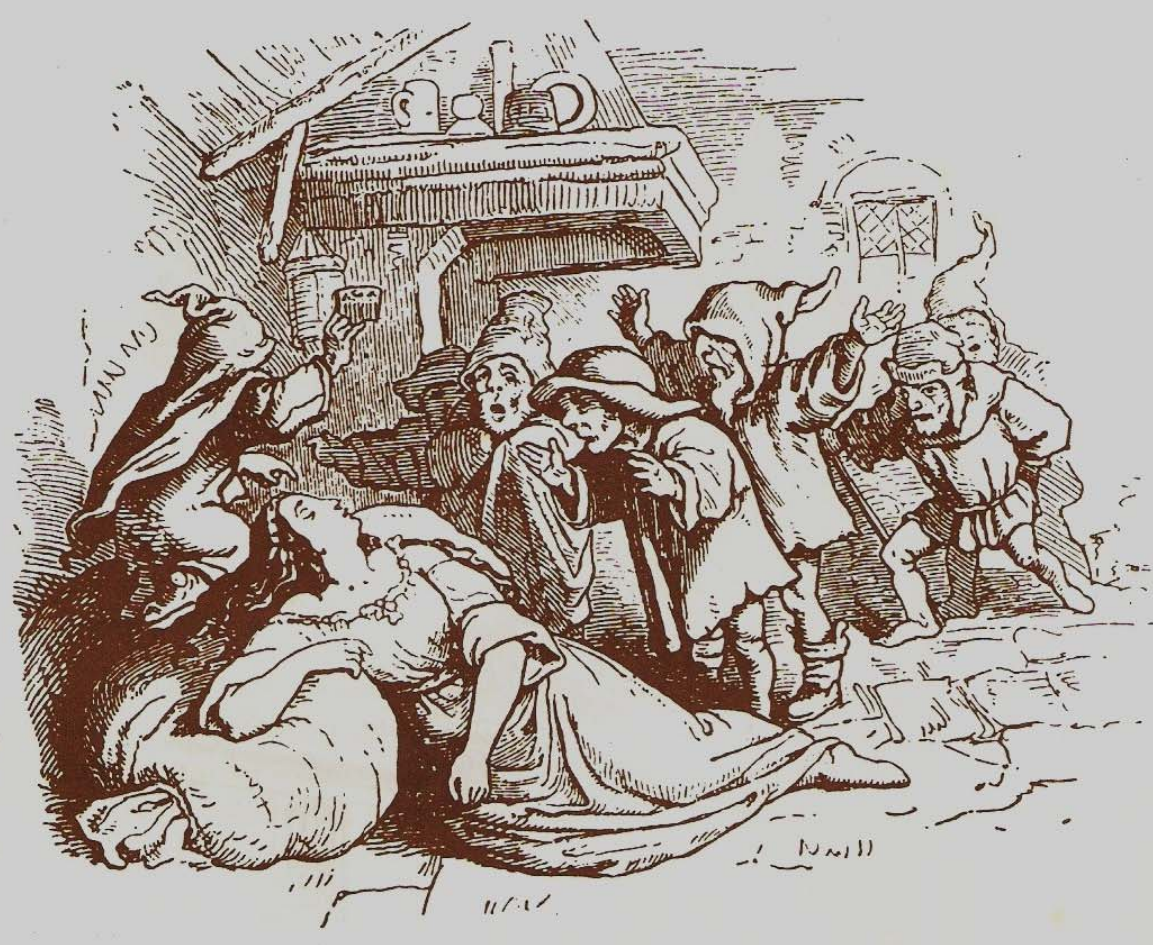

Quando voltaram para casa naquele dia, os sete anões encontraram Branca de Neve estendida no chão, imóvel, sem respirar: estava morta. Eles não se resignavam, porém, com aquela desgraça. Carregaram-na, procuraram por todos os modos animá-la, com massagens e sinapismos. Em vão, não adiantava esforço algum. Tiveram de colocá-la em um esquife e todos os sete sentaram ao redor, chorando sem parar durante três dias.

Era necessário enterrá-la, passados os três dias. Ela, porém, tinha toda a aparência de uma pessoa viva, com as faces coradas: como em vida, branca como a neve, vermelha como o sangue e os cabelos negros como o ébano. Então, em vez de enterrá-la, os anões levaram o esquife para o alto da montanha e um deles sempre ficava ao seu lado, protegendo-o. $\mathrm{E}$ as aves também vieram, e choraram com saudade de Branca de Neve. Primeiro uma coruja, depois um corvo e afinal uma pomba. 


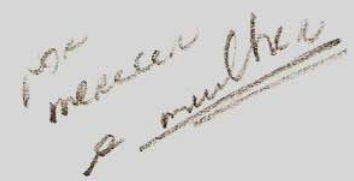

E Branca de Neve continuou por muito, muito tempo no esquife, tão bela como sempre, com uma expressão tranquila e angelical no rosto, como se estivesse apenas dormindo.

$\mathrm{E}$ aconteceu que um príncipe atravessou a floresta e chegou à casa dos anões, onde resolveu pernoitar. Viu o esquife na montanha e dentro dele a linda Branca de Neve e leu o que nele estava escrito com letras de ouro pelos anões, dizendo que se tratava de uma princesa.

E falou aos anões:

- Deixai-me levar o caixão, que vos darei em troca o que quiserdes.

Os anões, porém, responderam:

- Não nos separaremos dela nem em troca de todo o ouro que há no mundo!

- Dai-me, então, como um presente, pois não posso viver sem ver Branca de Neve - insistiu o príncipe. - Velarei por ela como o meu bem mais precioso.

Ouvindo aquelas palavras, os bondosos anões se apiedaram do príncipe e ofereceram-lhe o esquife de Branca de Neve como presente.

E o príncipe partiu levando o esquife, carregado nos ombros por seus servidores. E aconteceu que os servidores tropeçaram em um toco de árvore, e o esquife quase caiu, e balançou tanto que o pedaço envenenado de maçã que ela havia comido saltou para fora da garganta de Branca de Neve, onde estava atravessado. E logo em seguida ela abriu os olhos, levantou a tampa de vidro do esquife e sentou-se, viva e bem disposta.

- Onde estou, meu Deus do céu? - gritou.

- Estás comigo! - exclamou o príncipe, contando-lhe depois o que acontecera, e concluiu: - Amo-te mais do que qualquer coisa no mundo. Vem comigo ao palácio de meu pai. Serás minha esposa.

Branca de Neve aceitou o pedido sem relutância, e o casamento se realizou com a maior pompa e esplendor. A madrasta foi também convidada para a festa. E quando se viu metida em suas ricas e belas vestes e coberta de jóias, perguntou ao espelho mágico:

Dize a pura verdade, dize, espelho meu:

Há no mundo mulher mais bela do que eu?

E, para sua grande surpresa e imenso desespero, a resposta foi esta:

Aqui neste quarto sois vós, vós sozinha

Mas muito mais bela é a jovem rainha. 


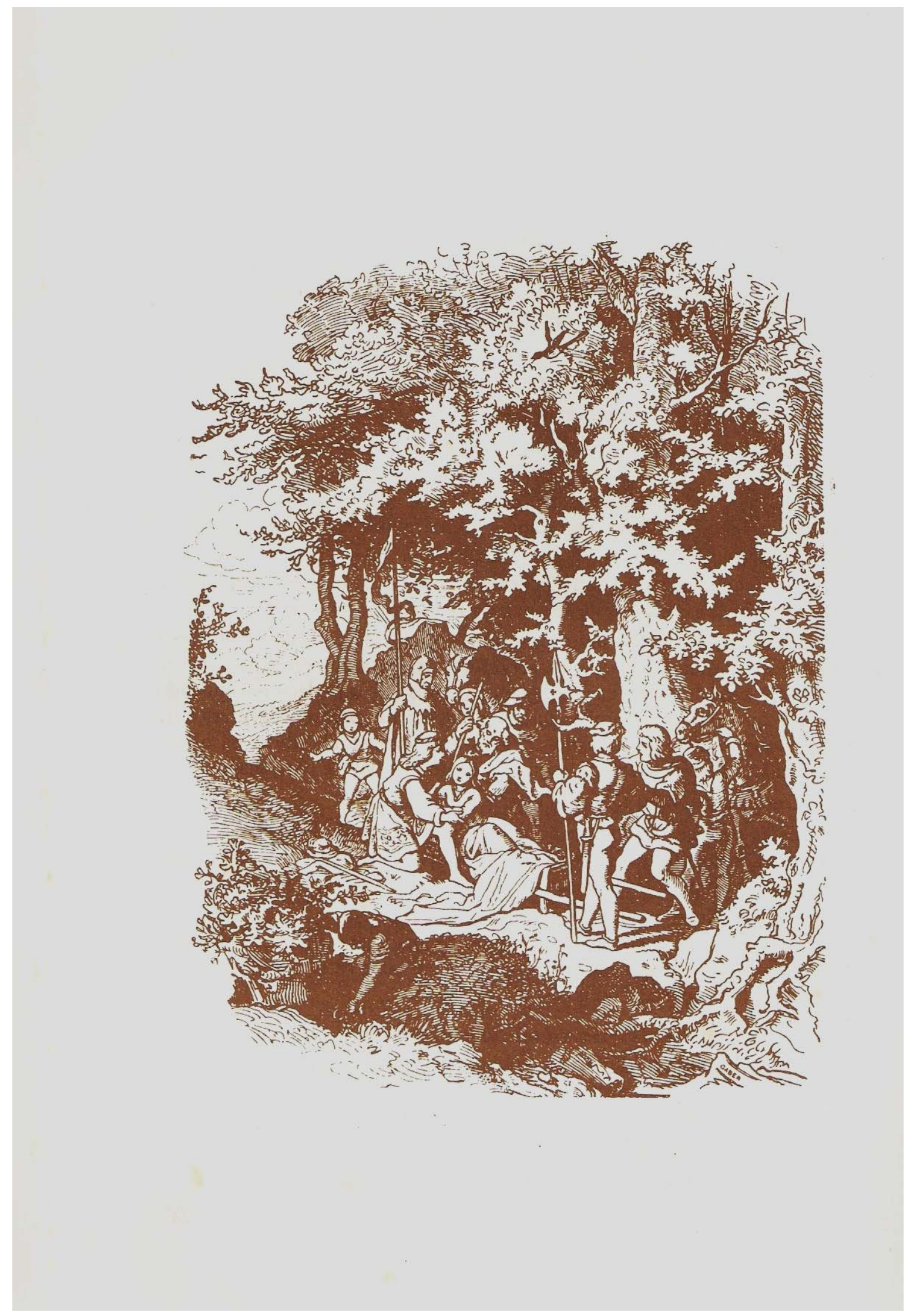




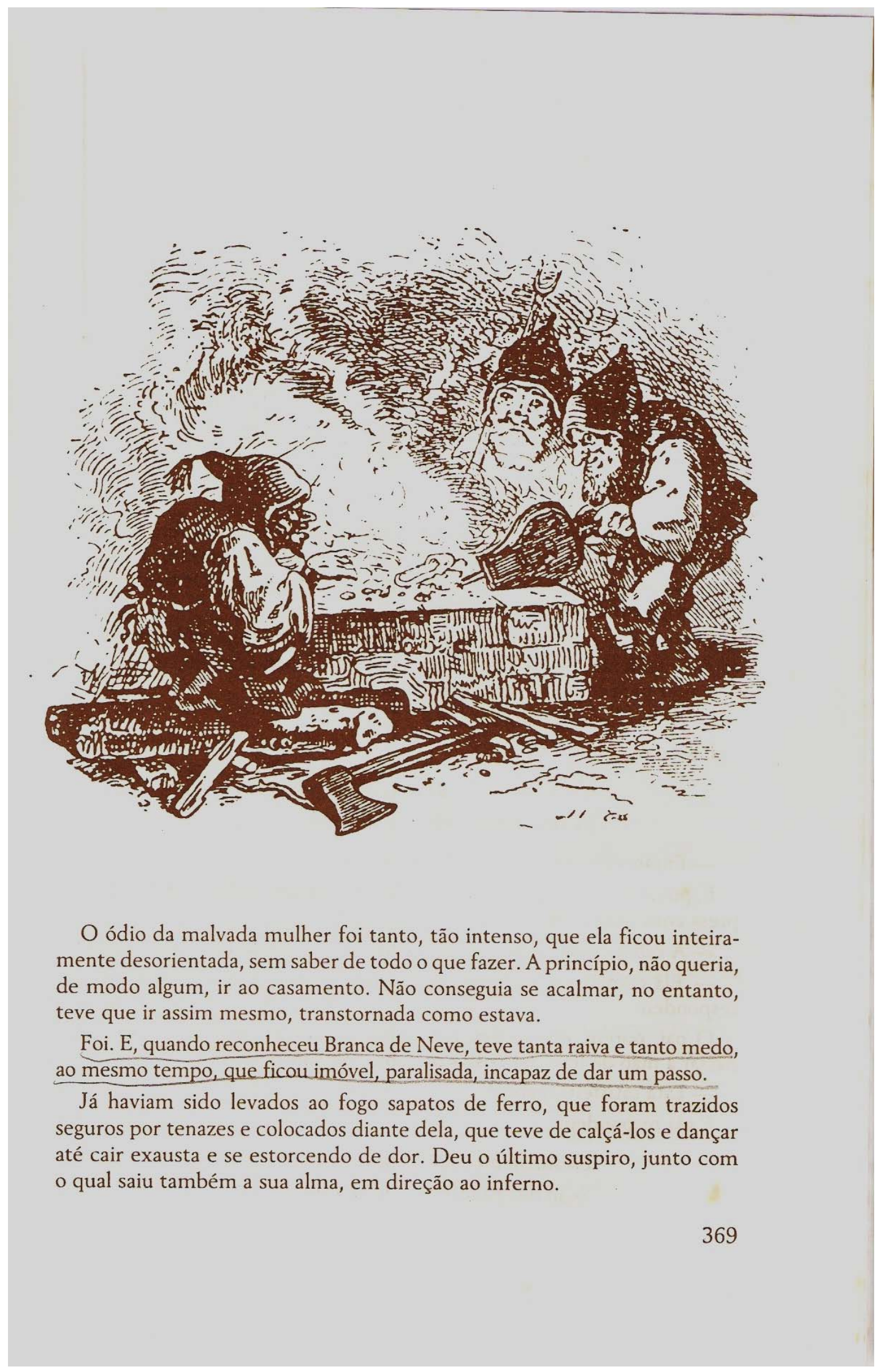




\section{A MULHER E A FILHA BONITA}

Uma vez havia uma mulher viúva que tinha uma filha muito bonita, e a mulher também era muito bela e tinha inveja da filha.

Um dia, passando em casa dela uns viandantes, a mulher lhes disse: "Os senhores já viram uma cara mais formosa do que a minha?" Eles responderam: "É muito bela; mas a sua filha ainda é mais." A mulher ficou desesperada e foi tomando ódio à filha.

Doutra vez passaram por lá outros caminheiros e ela lhes fez a mesma pergunta e teve a mesma resposta. Ficou ainda mais desesperada e mandou trancar a mocinha num quarto para não ser vista por ninguém. A menina sofria tudo com muita paciência e nada dizia.

No quarto em que ela estava, tinha uma janelinha que dava para o caminho, e uma vez que ela se animou a abri-la, vinham passando uns viajeiros e a viram.

Eles chegaram à casa e a mãe da mocinha lhes disse: "Os senhores já viram uma cara tão bonita como a minha?" Eles responderam. "É bonita; mas a da moça que está presa no quarto, ainda é mais." A mulher ficou desesperada e ordenou a um negro velho da casa que levasse a filha para os matos e lá 
a matasse. O negro levou a rapariga; mas chegando nas brenhas teve pena de a matar e deixou-a lá ficar, e cortou a ponta da língua de uma cachorrinha e levou à senhora, dizendo que tinha matado a moça. A mulher acreditou. A mocinha pôs-se a andar por aquela mata afora e, já sendo tarde, trepou numa grande árvore e muito ao longe avistou uma fumacinha. Desceu e dirigiu-se para lá, naquela direção. Depois de muito andar, lá chegou.

Era um grande palácio, porém não tinha gente e estava muito sujo. A moça arrumou tudo, e varreu toda a casa, limpou os trastes e pôs-se lá à espera. Este palácio era do Rei dos ladrões. Quando foi mais tarde a moça o viu chegar com a sua grande tropa, teve muito medo e se escondeu. Os ladrões ficaram muito gratos e procurando por toda a casa a encontraram. A moça encantou a todos os ladrões pela sua beleza, e já eles queriam brigar para ver quem a tinha de possuir e sem chegar a um acordo. Então o Rei dos ladrões propôs que a moça ficasse em casa morando com eles; mas que todos a tratassem e venerassem como se fosse uma irmã. Assim fizeram, e a mocinha ficou ali, descansada. Correram os tempos e chegou aos ouvidos da mãe que a filha estava viva e muito bem porque estava muito rica.

A mãe mandou chamar uma feiticeira e lhe pediu que procurasse a sua filha e lhe desse fim. A feiticeira aceitou a proposta e largou-se para a casa dos ladrões. Lá chegando à hora em que a moça estava sozinha, lhe fez grande festa dizendo: "Oh! minha netinha, há que tempo não te vejo! Tu mamastes nestes meus peitos! Trago-te aqui um presente de pobre; não achei nada para trazer e trago somente este parzinho de sapatos." A moça por 
delicadeza aceitou os sapatos e logo que os calçou caiu pra trás como morta. A velha raspou-se às carreiras. Quando os ladrões chegaram, acharam a moça morta e ficaram muito tristes. Pegaram nela, botaram num bonito carro e mais muito dinheiro e uma recomendação que quem a encontrasse, que enterrasse no sagrado, porque eles não podiam ir à cidade enterrá-la.

Um filho do rei, que andava caçando, encontrou o carro e abriu o caixão, e vendo a moça, ficou tão namorado que, em lugar de a enterrar, a levou para o palácio e a guardou no seu quarto com toda a riqueza que encontrou.

E a moça sempre a dormir e o príncipe quase doido de paixão. Não deixava ninguém ir a seu quarto; mas uma vez, estando ele fora, a princesa sua irmã teve curiosidade de ir ao quarto ver o que era que lá havia.

Chegou, abriu o caixão e viu a moça e achou tão bonita e estranhou que ela estivesse com uns sapatos tão feios de couro. Puxou os sapatos e a moça suspirou e sentou-se pedindo água.

A princesa deu-lhe água, tornou a calçar-lhe os sapatos, e a moça adormeceu de novo.

Quando o príncipe veio, a irmã lhe disse: "Se me deres daquele dinheiro que encontraste, eu descubro um segredo que há em teu quarto." O príncipe concordou e a princesa desencantou a moça. Houve uma grande festa e o príncipe casou-se com a linda moça. No fim dos nove meses ela deu à luz a dois meninos, a coisa mais linda que dar-se podia. Mas veio servir de parteira justamente a feiticeira que tinha-lhe dado os sapatos, e, em lugar dos dois meninos, apresentou um sapo e uma jia. O príncipe 
andava ausente numas guerras e o pai the mandou dar parte do acontecido. O príncipe mandou dizer ao pai que matasse a mulher; mas o rei teve pena e somente lhe cortou um dos peitos e a expulsou de casa.

A moça saiu pelo mundo afora; tendo muita sede chegou a uma fonte e bebeu água; passou água no peito e o peito tornou a crescer. Aí, ela seguiu viagem e foi ter à casa de um gigante e tomou um rancho lá com os seus dois filhos, porque os filhos a feiticeira lhe entregou. Muito tempo depois, andando o príncipe em caçadas, passou pela casa do gigante e viu os dois meninos e tomou por eles muita afeição. Noutros dias, continuou as suas caçadas e sempre passava pela casa do gigante, até que um dia viu a sua mulher. Muito se arrependeu do que tinha feito e tornou a viver com ela, mandando matar a feiticeira.

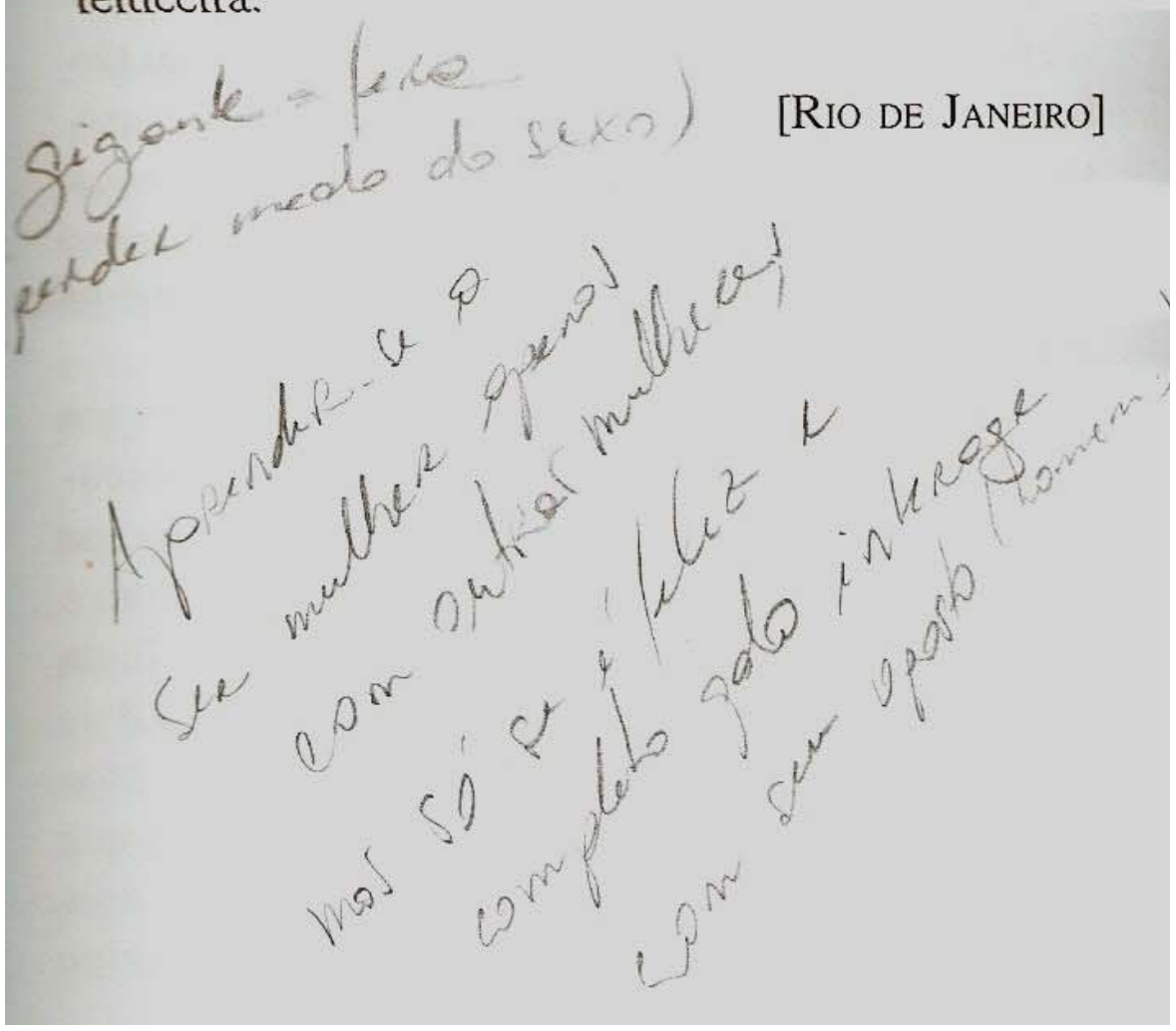


55.

RAPUNZEL

Era uma vez um casal cujo maior desejo era ter um filho. Os anos iam se passando, e o filho não vinha. Afinal, a mulher ficou esperançosa de que Deus ouviria suas preces.

$\mathrm{Na}$ casa em que morava o casal havia no fundo uma janelinha, da qual podia-se ver um esplêndido jardim repleto das mais belas flores e folhagens. Era, porém, cercado por um muro muito alto e ninguém se atrevia a entrar nele, pois pertencia a uma feiticeira que tinha grandes poderes mágicos e era temida por todo mundo.

Certo dia, a mulher estava contemplando o jardim da bruxa, através da janelinha, quuando avistou um canteiro de belos rapúncios, tão verdinhos e parecendo tão frescos, que ela, que gostava muito daquela verdura, sentiu muita vontade de comê-la. Essa vontade foi aumentando de dia para dia, e, como sabia que o seu desejo não poderia ser satisfeito, ela começou a emagrecer e empalidecer, até que o seu estado de fraqueza alarmou o marido, que lhe perguntou:

- O que está te afligindo, minha querida?

— Ah? - ela replicou. - Se eu não comer um pouco do rapúncio que se vê daqui no quintal da bruxa, eu vou morrer.

O marido, que amava muito sua esposa, pensou: "Em vez de deixar minha esposa morrer, tenho de trazer-lhe alguns rapúncios, custe o que custar".

E, assim pensando, ao anoitecer pulou o muro da casa da bruxa, apanhou alguns rapúncios e levou-os para a mulher, que, imediatamente, preparou com eles uma salada, devorando-a, por assim dizer. Gostou tanto que, no dia seguinte, quis comer três vezes mais salada de rapúncio do que comera na véspera. Para ter algum sossego, seu marido teve de pular outra vez o muro da casa da bruxa. 


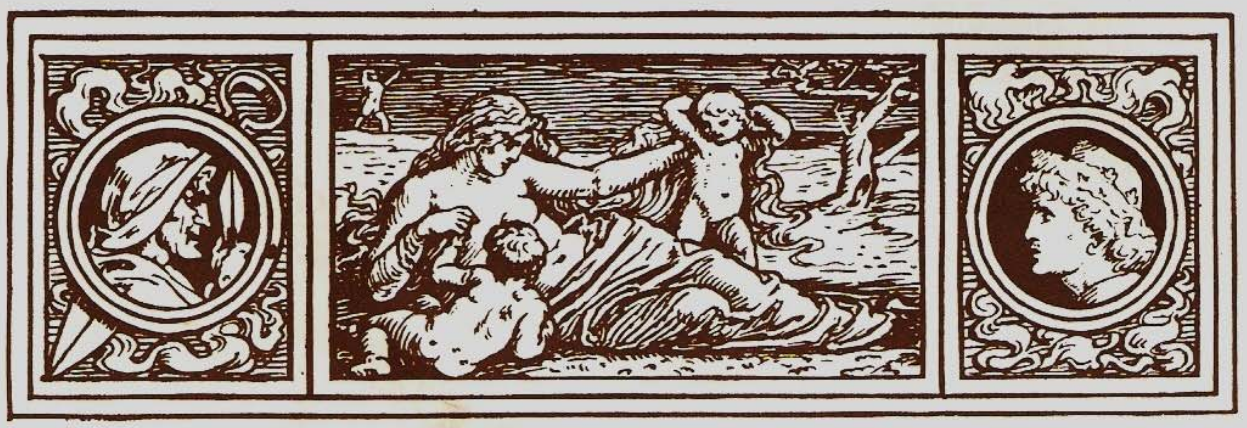

Aproveitou de novo a escuridão noturna. Ao descer do muro, porém, ficou apavorado, vendo a feiticeira de pé, à sua frente.

- Como te atreves a entrar no meu quintal e furtar meu rapúncio, como um ladrão? - ela perguntou.

- Ah! - exclamou o homem. - Fui forçado a fazer isso por causa de uma necessidade absoluta. Minha mulher viu os rapúncios daqui, de uma janela da nossa casa, e ficou com tanta vontade de prová-los, que morreria certamente, se não comesse alguns.

A feiticeira, então, dominou a raiva e disse ao homem:

- Se é assim como dizes, vou permitir que leves tantos rapúncios quanto quiseres, mas com uma condição: terás de me dar a filha que tua mulher vai dar à luz. Ela será muito bem tratada, e cuidarei dela como se fosse minha filha.

Apavorado, o homem concordou, e, logo que sua mulher deu à luz uma menina, a bruxa apareceu, deu à recém-nascida o nome de Rapunzel (rapúncio) e levou-a consigo.

Rapunzel tornou-se a criança mais linda que havia sobre a face da Terra. Quando tinha doze anos, a bruxa trancou-a em uma torre no meio da floresta e que não tinha escadas nem portas, mas tinha uma janelinha bem no alto. Quando a feiticeira queria entrar na torre, colocava-se diante da janela e cantava:

\section{Rapunzel, Rapunzel! \\ Desce os teus cabelos.}

Rapunzel, então, deixava cair fora da janela a sua comprida cabeleira, e a bruxa subia se agarrando a ela, como se fosse uma corda.

Um ou dois anos depois, aconteceu que o filho do Rei entrou na floresta e passou pela torre. Ouviu, então, um canto, tão belo, que ele parou para ouvir. Era Rapunzel, que, em sua triste solidão, cantava para os males espantar. $\mathrm{O}$ 
príncipe quis subir na torre, para ver a cantora, e procurou a porta da torre, mas porta alguma foi encontrada. Ele voltou para o palácio de seu pai, mas o canto o comovera tanto, que todos os dias ia à floresta para escutá-lo.

Certa vez, quando estava ouvindo, atrás de uma árvore, viu a feiticeira chegar e ouviu o que ela cantava:

\section{Rapunzel, Rapunzel! \\ Desce os teus cabelos.}

Rapunzel tinha os cabelos extraordinariamente longos, brilhantes como ouro, e, quando ouviu a voz da feiticeira, desatou as tranças e soltou na janela a magnífica cabeleira, que desceu vinte varas de extensão, e a bruxa subiu, agarrando-se a ela.

- Se essa é a escada pela qual se sobe, eu também vou tentar minha sorte - murmurou o príncipe.

E, no dia seguinte, quando começou a anoitecer, foi até a torre e cantou:

\section{Rapunzel, Rapunzel!}

Desce os teus cabelos.

Imediatamente o cabelo desceu e o príncipe subiu.

A princípio, Rapunzel ficou terrivelmente assustada ao ver aproximar-se um homem que jamais vira antes. O príncipe, porém, começou a falar-lhe com doçura, e disse-lhe que o seu coração tinha ficado tão tocado por seu canto, que não tivera mais sossego desde que o ouvira e tivera de procurar a cantora.

Rapunzel perdeu o medo, e, quando o príncipe lhe perguntou se a. aceitaria como marido, e viu que ele era moço e bonito, pensou que ele a amaria mais do que a velha Senhora Gothel, e disse que sim, deixando quet ele lhe tomasse as mãos entre as dele.

- Eu te acompanharei de boa vontade, mas não sei como sair daqui disse. - Todas as vezes que subires aqui, traze contigo uma meada de seda, e vou tecer com elas uma escada, e, quando ela ficar pronta, eu descerei e partirei contigo em teu cavalo.

Os dois combinaram que ele iria vê-la todas as noites, pois a bruxa ia durante o dia.

A feiticeira nada notou, mas ficou sabendo, no dia em que Rapunzel, inadvertidamente, lhe disse:

- Por que será, senhora Gothel, que é tão mais difícil para mim sustentar nos meus cabelos a senhora do que o jovem príncipe? 

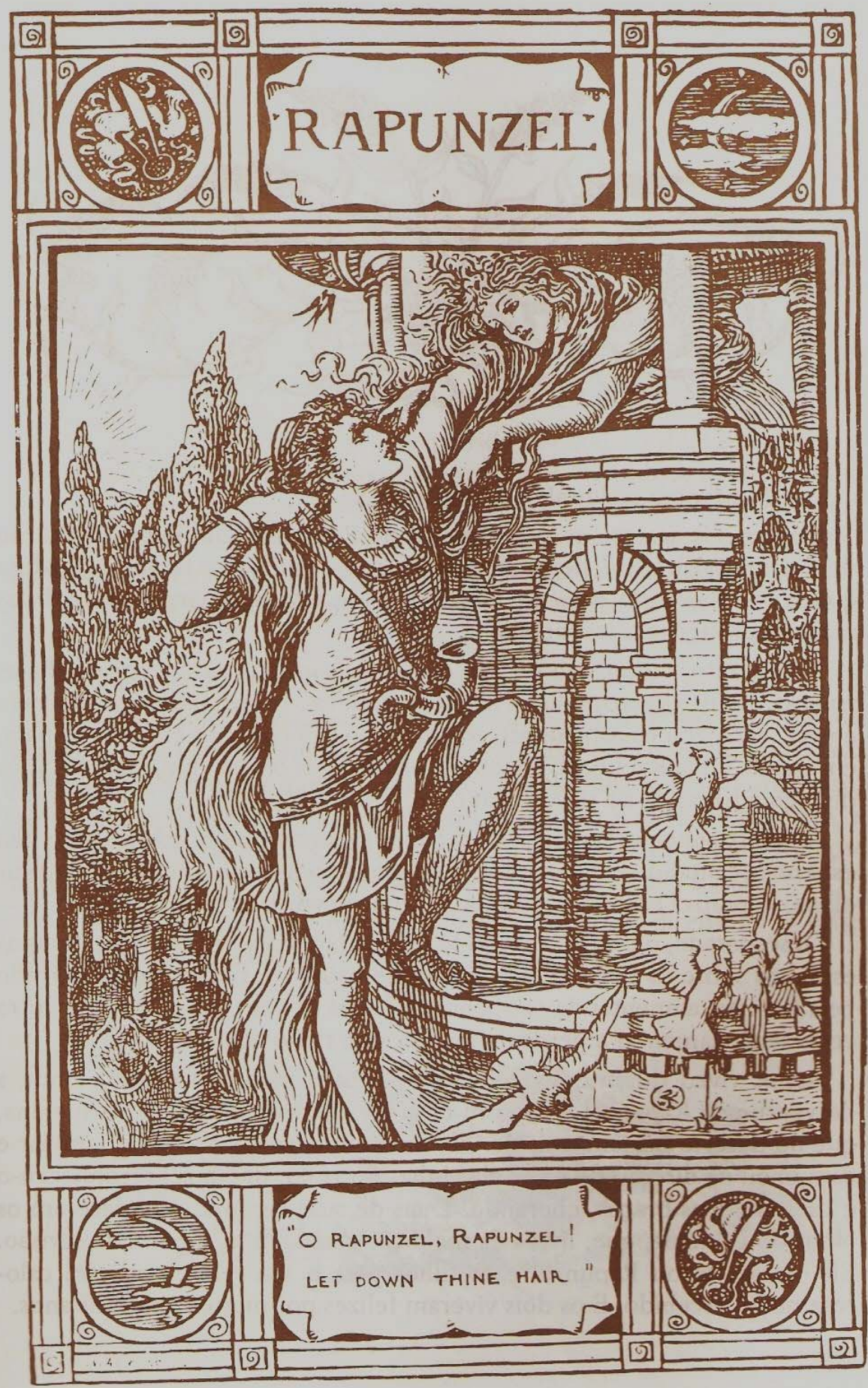


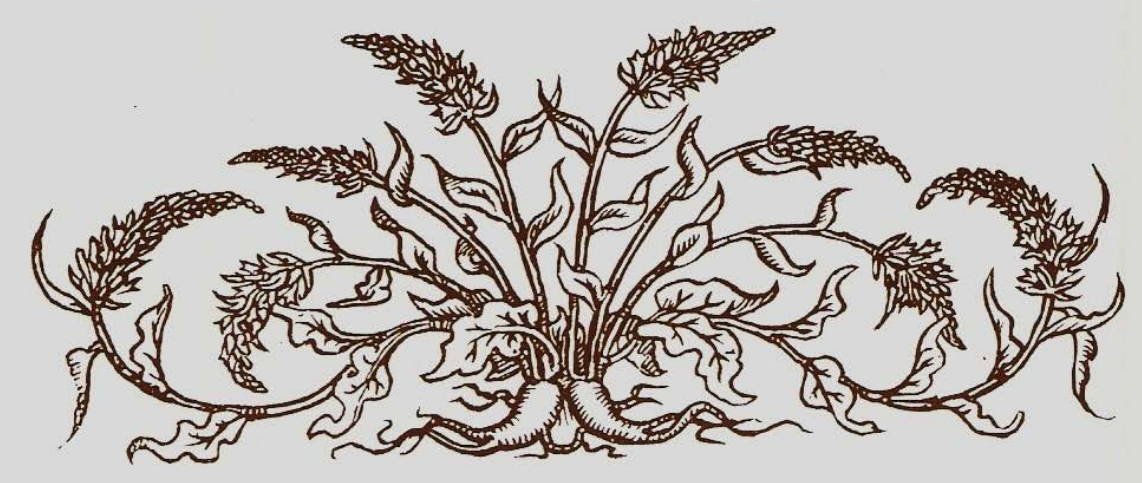

- Ah! Menina maldita! — gritou a bruxa.

Furiosa, ela agarrou as belas tranças de Rapunzel, enrolou-as em torno de seu punho direito e, pegando uma tesoura, cortou-as, e foi tão impiedosa que levou Rapunzel para um deserto, onde teve que viver, sofrendo as maiores privações, desesperada.

No entanto, no mesmo dia em que expulsou Rapunzel e cortou-lhe as tranças, a bruxa amarrou-as na janela e, quando o príncipe deu a senha para entrar, ela jogou os cabelos até embaixo e o príncipe por eles subiu, para, em vez da linda Rapunzel, encontrar a horrorosa bruxa, que, com os olhos de fogo e babando de raiva, gritou-lhe:

- Vieste encontrar tua querida? Fica sabendo que o belo pássaro não está mais cantando em seu ninho. O gato comeu e vai também furar teus olhos. Rapunzel está perdida para ti. Nunca mais irás vê-la.

Desesperado, o príncipe jogou-se para baixo. Escapou com vida, mas os espinhos sobre os quais caiu furaram-lhe os olhos. Então, vagou perdido pela floresta, alimentando-se apenas de frutas e raízes, e não fazendo outra coisa senão lamentar a perda da mulher que tanto amava.

Assim viveu durante alguns anos e afinal chegou ao deserto onde a desventurada Rapunzel vivia com os gêmeos, um menino e uma menina, que no deserto haviam nascido. Ele ouviu uma voz que the era familiar e caminhou na direção de onde ela vinha. Ao vê-lo, Rapunzel reconheceu-o e caiu em seus braços, chorando. Duas de suas lágrimas umedeceram os olhos do príncipe, que, livres da maldição da bruxa, recuperaram a visão. Ele, então, levou Rapunzel e os filhos para o seu reino, onde foi calorosamente recebido. $\mathrm{E}$ os dois viveram felizes por muitos e muitos anos. 